\author{
С.И. Миронова, В.В. Иванов
}

\title{
ДОБЫЧА УГЛЯ В ЮЖНОЙ ЯКУТИИ И ЕЕ ВОЗДЕЙСТВИЕ НА РАСТИТЕЛЬНОСТЬ (на примере разреза «Нерюнгринский»)
}

Монография

\author{
Рекомендовано УМО РАЕ \\ по классическому университетскому \\ и техническому образованию в качестве \\ учебного пособия для студентов \\ высших учебных заведений, \\ обучающихся по специальности \\ 050406 - Экология и природопользование
}


УДК 581.55:504.062.4

ББК 20.18

M64

\section{Aвторы:}

Миронова Светлана Ивановна, Иванов Василий Васильевич

\section{Рещензенты:}

Черосов М.М. - доктор биологических наук.

Бурцева Е.И. - доктор биологических наук.

Миронова С.И., Иванов В.В.

M64 Добыча угля в Южной Якутии и ее воздействие на растительность (на примере разреза «Нерюнгринский»): монография / С.И. Миронова, В.В. Иванов. - М.: Евроазиатская научнопромышленная палата, 2019. - 102 с.

ISBN 978-5-6043109-4-6

DOI 10.17513/np.371

В монографии приведены результаты многолетних исследований по развитию угледобывающей промышленности в Южной Якутии (разрез «Нерюнгринский») и техногенной трансформации растительного покрова территории. На основе эколого-биологических исследований выявлены закономерности развития посттехногенной растительности и определены способы биологической рекультивации для ускорения восстановления природной среды.

Монография рассчитана для биологов, экологов, специалистов по охране окружающей среды.

Утверждено к печати Ученым Советом НИИПЭС СВФУ. 


\section{ОГЛАВЛЕНИЕ}

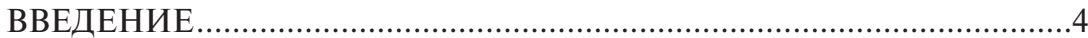

Глава 1. НЕДРОПОЛЬЗОВАНИЕ В ЯКУТИИ ....................................6

1.1. Развитие угольной промышленности в Южной Якутии .........10

1.2. Особенности технологии добычи угля ....................................15

Характеристика выбросов Нерюнгринского разреза ........................15

1.2.1. Краткая характеристика предприятия ...............................15

1.2.2. Основные источники выбросов на разрезе.......................25

1.2.3. Краткий анализ данных по выбросам

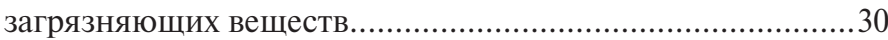

Глава 2. ПРИРОДНО-КЛИМАТИЧЕСКИЕ



Глава 3. РАСТИТЕЛЬНЫЙ ПОКРОВ РЕГИОНА ..............................42

3.1. Естественная растительность.................................................45

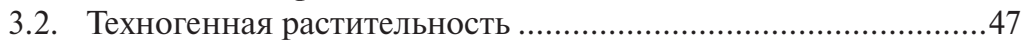

ГЛава 4. ТЕХНОГЕННЫЕ ИЗМЕНЕНИЯ РАСТИТЕЛЬНОСТИ

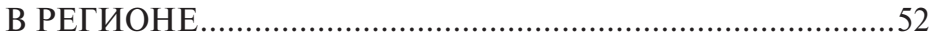

4.1. Изменения в лишайниковом покрове .................................58

Глава 5. ОПТИМИЗАЦИЯ ТЕХНОГЕННОЙ

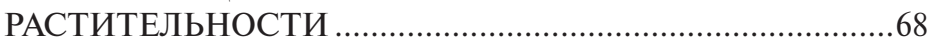

5.1. Биологическая рекультивация на отвалах угольных месторождений .................................................................. 71

5.2. Опыты по биологической рекультивации на отвалах разреза «Нерюнгринский» .................................................75

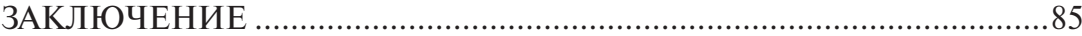

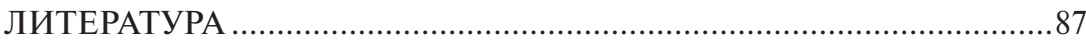




\section{ВВЕДЕНИЕ}

Природопользование как наука рассматривает проблемы охраны окружающей среды, экологии и экономики производства для удовлетворения потребностей общества путем использования различных видов природных ресурсов или хозяйственно-экономическая деятельность общества, направленная на использование природных ресурсов с целью извлечения из них материальных благ. А использование недр для регионального геологического изучения, поиск, оценка и разработка месторождений полезных ископаемых составляет недропользование, т.е. использование земель различных категорий, в том числе специального назначения (промышленности, энергетики), изымаемые из хозяйственного оборота.

Промышленное освоение природных ресурсов, особенно на $\mathrm{Ce}$ вере, оказывает неизлечимую рану природной среде. Еще в 1931 г. академик А.Е. Ферсман первым ввел в научный оборот термин «техногенез», под которым он подразумевал процесс индустриального изменения биосферы, особо выделяя геохимическую деятельность человека (Ферсман, 1931, 1934). Он показал основные области влияния человеческой деятельности на геохимические процессы в условиях зоны гипергенеза и на глубинах, доступных геологоразведочным работам и добыче полезных ископаемых, а также масштабы ее проявления. Наиболее важными из них уже в то время он отмечал горнодобывающую и металлургическую промышленность.

Наиболее разрушительное наступление человека на природу происходило во второй половине XX столетия, которое оказалось гораздо большим, чем за всю предыдущую человеческую историю. В глобальном масштабе трансформация земных ландшафтов человеком проявилась в том, что леса уступили место лесопольным и лесолуговым ландшафтам, а полевые и сельскохозяйственные ландшафты заняли место степных и лесостепных комплексов (Мильков, 1970; Федотов, 1985). 
Якутия известна в мире как кладовая полезных ископаемых, где основная добыча ведется открытым способом, принося огромные убытки природной среде.

Южная Якутия уже около 100 лет является центром добычи золота и полиметаллов, угля и других видов полезных ископаемых. До последнего времени основным поставщиком угля был разрез «Нерюнгринский», в настоящее время первенствует Эльгинское месторождение в разы превышающее запасы высококачественного угля. В этой связи настала пора определить степень воздействия открытой добычи угля на окружающие экосистемы, и в первую очередь на растительный покров. Именно растительность является прямым индикатором состояния природной среды, т. к. первые нарушения поверхности месторождения отмечаются в ней.

Целью наших исследований является изучение флоры и растительности в зоне влияния разреза «Нерюнгринский» при недропользовании.

Перед нами поставлены следующие задачи:

1) привести краткий обзор недропользования Южной Якутии;

2) провести анализ состояния естественной и техногенной растительности;

3) на основе изучения восстановительной сукцессии на техногенных ландшафтах определить методы и способы их оптимизации.

Работа выполнена в НИИПЭС СВФУ в рамках выполнения государственного задания Минобрнауки России 5.8169.2017/8.9). ЗАДАНИЕ №5.8169.2017/БЧ на выполнение проекта по теме «Исследование сукцессий экосистем Севера под воздействием антропогенных факторов». 


\section{Гдава 1. НЕДРОПОЯЬЗОВАНИЕ В ЯКУТИИ}

Государственными программами в области охраны окружающей среды и обеспечения экологической безопасности некоторых субъектов на северных ерриториях Российской Федерации предусматриваются меры экономического регулирования в указанной сфере при пользовании недрами (системы государственно-частного партнерства, развитие инвестиционных проектов, предоставление налоговых и иных льгот при внедрении наилучших доступных технологий, повышение эффективности использования попутного и природного газа, снижение объемов сжигаемого газа и т. д.).

Недропользование характеризует деятельность по добыче, переработке и использованию минеральных ресурсов и является одним из основных видов природопользования.

В Якутии недропользование стало широко развиваться с 20-х годов прошлого века и в настоящее время стало ведущей отраслью экономики и осуществляется в специфических природных условиях почти по всей территории республики.

В литературе встречаются материалы, свидетельствующие об использовании якутами Лены до 1621-1630 гг. технологии кустарной добычи железной руды и ее обработки для производства пальм, наконечников стрел, копий и ножей (Уткин, 1992, Маак, 1887, и Серошевский, 1896). В это же время, наряду с железорудным делом якутские мастера того времени производили высокохудожественные украшения из серебра, ковали медные изделия (Уткин, 1992).

По территории Якутии в конце XIX в начале XX вв. проводились многочисленные экспедиции известных исследователей С.П. Гмелина и С.П. Крашенникова (1733-1743 гг.), И.И. Биллингса (1786-1794 гг.), Г.А. Сарычева (1802 г.), А.Ф. Миддендорфа (1842-1845 гг.), Н.Г. Меглицкого (1849-1851 гг.), Р.К. Маака (1854-1855 гг.), А.Л. Чекановского (1873-1875 гг.), И.Д. Черского (1882-1893 гг.), А.А. Бунге и Э.В. Толля (1882-1884 гг.), В.А. Обручева (1882-1947 гг.). В ходе данных экспедиций накапливался обширный материал по географическим и биологическим особенностям региона. В то же время, по заключению специальной комиссии Геологического комитета в 1909 г., с точки зрения геологии и запасов минеральных ресурсов территория Северо-Востока Сибири принадлежала к числу наименее изученных на всем земном шаре (Геология Якутской АССР, 1981). 
По территории Южной Якутии поиски золота начались в конце XIX в. и в 1896 г. П.П. Аллаковым было заявлено в Якутское полицейское управление об открытии новых золотоносных площадей вблизи водораздела рек Брянта и Сутам (Алексеев, 2010).

Уже в 1899 г. развернулись разработки золотоносных песков в бассейнах рек Джалинда, Тимптон, образовались прииски Алексеевский, Скобеленский, Адмиральский и группа Лебединских приисков, которые вели активную добычу россыпного золота.

Считается, что наибольшего размаха добыча золота в предреволюционные годы достигла в период между 1902 и 1912 годами. К этому времени в бассейне верховий Алдана стала действовать Верхне-Амурская золотопромышленная компания (ВАЗКО), работавшая вплоть до 1917 года и открывшая ряд новых россыпных месторождений (Алексеев, 2010).

Технология кустарных или полукустарных промыслов по добыче россыпного золота заключалась в перегораживании каскадом земляных плотин участок ручья или речки, для укрепления которых забивались лиственничные сваи. В некоторых случаях для сбора воды в количествах необходимых для промывки песков проходились нагорные канавы.

Воздействие на природную среду проявлялись главным образом на водные и наземные экосистемы малых и средних водотоков загрязнениями продуктами ручной промывки золотоносных песков, образованием взвесей мелких частиц при сооружении плотин и канав, и в виде значительно возросшего охотничьего давления, в вылове рыбы. Главный ущерб природе был связан с вырубками леса для устройства пожогов с целью оттаивания мерзлого грунта и участившимися лесными пожарами, связанными чаще всего именно с разработками россыпей.

Огромное значение в историю изучения Российского Севера внесли экспедиции великих русских ученых начала XX в. на Новую Землю и Шпицберген Ф.Н. Чернышева и В.А. Русанова, на севера европейской части России и Сибири Г.Л. Брусилова, Г.Я. Седова, Ф.Б. Шмидта, А.Л. Чекановского, И.П. Толмачева, в прибрежные районы северо-восточных морей П.А. Кропоткина, А.А. Бунге, Э.В. Толля, И.Д. Черского и др., в результате которых составлялись материалы по гидрографии, географии, геологии, полезным ископаемым, флоре и фауне ранее не исследованных территорий. Во многих отчетах участников экспедиций подчеркивались уникальность, перспективность освоения угольных, графитовых, медных руд и других полезных ископаемых.

В 1915 г. с целью «произвести по возможности полный учет наших богатств, выяснить степень их использования» Российской Академией наук под руководством академика В.И. Вернадского была создана 
комиссия по изучению естественных производительных сил и природных ресурсов страны.

В начальный период изучения огромной территории Якутии были заложены основы изучения природных условий и геологического строения северных земель, основы технологии добычи и переработки полезных ископаемых для суровых природно-климатических условий, накоплен значительный материал о месторождениях многих минеральных ресурсов на Севере, начаты разработки наиболее ценных из них. Набранный материал позволял ученым наметить дальнейшие перспективы более глубокого изучения региона, прогнозировать открытие новых районов расположения ценнейших, стратегически важных для экономики государства минеральных ресурсов.

Вместе с тем, уже в этот период обозначились и некоторые негативные экологические последствия активизации хозяйственной деятельности на Севере. Так, например, произошли резкое сокращение численности наиболее ценных пушных зверей, изменение экосистем вследствие массовых пожаров в районах разработки месторождений полезных ископаемых, вынужденное переселение коренного населения в труднодоступные и отдаленные места.

В изучении биологических и недровых богатств Якутии наиболее значительное влияние сыграла комплексная экспедиция, которая была организована в 1925 г. Академией наук СССР с целью изучения производительных сил Якутской АССР, в составлении программы которой и в ее реализации принимали участие академики С.Ф. Ольденберг, А.Е. Ферсман, В.Л. Комаров, Ф.Ю. Левинсон-Лессинг, А.П. Карпинский, В.В. Бартольд, Л.С. Берг, А.А. Григорьев, К.Д. Глинка, В.А. Обручев, А.А. Борисяк и другие.

Дальнейшие геологические исследования и прогнозы Ю.А. Билибина, В.С. Соболева и Г.Г. Моора, рекомендации Н.В. Черского позволили открыть на территории Якутии целый ряд крупных месторождений самых различных полезных ископаемых, на основе которых зародилась и окрепла вся горнодобывающая отрасль республики.

Бурное развитие недропользования в Якутии связано с широким освоением крупнейших месторождений золота, алмазов, угля, нефти и газа, олова и других полезных ископаемых. Для успешной добычи ресурсов образовались крупные населенные пункты и их инфраструктуры (транспортная и инженерные сети, комплексы для переработки и размещения отходов производства и потребления, энергоснабжающие системы и устройства, комплексы по перегрузке и размешению грузов, товаров, строительных материалов и т.д.). 
Для всех этих мероприятий отводились огромные площади нетронутых до этого территорий, подвергались вырубке леса, землеройной техникой перелопачивались многомиллионные кубометры почвенно-растительного покрова, перекрывались реки и ручьи, изменялись их русла, переселялись населенные пункты (в иных случаях затоплялись) и т.д.

Определенные изменения в сфере недропользования в Якутии, да и по всей России произошли в перестроечный и постсоветский период. Из-за различных преобразований, сокращений, разрыва экономических связей с поставщиками техники, снабженческими организациями и заинтересованными в минеральных ресурсах потребителями многие добывающие предприятия резко снизили объемы горных работ, некоторые из них прекратили свою деятельность или распались на более мелкие структуры, другие изменили свой юридический статус.

Например, в Якутии компания «Алданзолото» в 1998 году сумело сдать государству всего 1882 кг драгоценного металла. В этот же период произошло раздробление предприятия «Алданзолото» на несколько самостоятельных добычных производств.

Прекратили свою деятельность производственное объединение «Якутзолото», горно-обогатительные комбинаты «Куларзолото», «Индигирзолото», «Дзугджурзолото». Вместо них появились множество мелких предприятий различной формы собственности.

По данным Е.Г. Егорова динамика золотодобычи в этот период в республике выглядела следующим образом: 1991 г. - 35,3 т; 1995 г. - 26,2 т; 1997 г. - 19 т; 1999 г. - 13,81 т и 2001 г. - 16,1 т. (Егоров, 2006).

Только после 2000 г. предприятия недропользования в республике начинают показывать более стабильные и нарастающие объемы добычи полезных ископаемых.

В настоящее время масштабы горнопромышленной деятельности неуклонно возрастают, распространяясь к северу Якутии, и охватили практически всю ее территорию (рис. 1.1).

Характерной особенностью современного этапа развития недропользования на Российском Севере является резкое выдвижение на первый план в северном природопользовании освоения двух основных видов природных ресурсов: возобновляемых (прежде всего лесных и в целом биологических) и не возобновляемых - peсурсов недр. При этом недропользование становится доминирующим видом природопользования и хозяйственной деятельности в целом. Именно этот фактор становится источником и причиной экологической дестабилизации северных территорий, охваченных недропользованием. 


\section{1. Развитие угодьной промышленности в Южной Якутии}

Считается, что горная промышленность в Южной Якутии берет начало с 1923 г., когда вольным разведчиком якутом Михаилом Тарабукиным было открыто уникальное россыпное месторождение золота по долине ручья «Незаметный», а в 1925 г. геологический отряд В.Н. Зверева обследовал бассейны рек Селигдар, Томмот, Куранах и обнаружил ряд золотоносных районов. Это позволило профессору В.А. Обручеву сделать заключение о генезисе золотых приисков Алдана (Антонов, 2002). В этом же году был создан Всесоюзный трест «Алданзолото», в составе которого открылись прииски Лебединый, Золотой, Турук, Орочен и др.

Уголь на территории Якутии впервые обнаружил в 1736 году И.Г. Гмелин во время второй Камчатской экспедиции на Сургуевом камне (Кангаласское месторождение) [1].

Сведения об угленосности мезозойских образований в ЯкутскоКангаласском районе появились в первой половине XIX в. в публикациях известных исследователей Сибири Зауера, Врангеля, Миддендорфа, Чекановского, Доленко, Никифорова. Об угле Кангаласского месторождения было известно участникам экспедиции Беринга, Белингса и Са-рычева [2].

В настоящее время на территории Якутии выделяются Южно-Якутский, Ленский, Зырянский угольные бассейны и восточная часть Тунгусского бассейна (рис. 1.1).

Основные угольные ресурсы сосредоточены в 3-х крупных бассейнах:

- Южно-Якутского угольного бассейна (более 40,0 млрд тонн).

- Зырянского бассейна (более 8,5 млрд тонн).

- Ленского бассейна (порядка 840 млрд тонн).

В Якутии угледобывающая промышленность в структуре объёма производства отраслей промышленности занимает третье место после нефтедобывающей и алмазодобывающей промышленности.

На территории республики угледобывающие предприятия, называвшиеся первоначально рудниками, начали действовать с 1928 г., когда был запущен Сангарский рудник. В последующие годы добыча угля была организована в Кангаласском (1930 г.), Чульманском (1934 г.), Зырянском (1936 г.) и Джебарики-Хайском (1940 г.) рудниках (Хатылаев, 1992).

Развитие угольной отрасли в северо-восточных регионах СССР обуславливалось потребностями в энергетике для промышленного освоения этих территорий. Но в целом угледобыча на Северо-Востоке России в 1920-1940 гг. развивалось медленными темпами из-за сложностей 
организации материально-технического снабжения в суровых условиях Севера, нехватки ремонтно-механических мощностей, запасных частей, что вело к длительным остановкам производства. Своеобразный контингент рабочих, инженерно-технического персонала, состоявших зачастую из заключенных ГУЛАГа, «спецпоселенцев», бывших военнопленных, отличался низкой квалификацией, что мешало достигать высокой производительности труда в угольных шахтах.

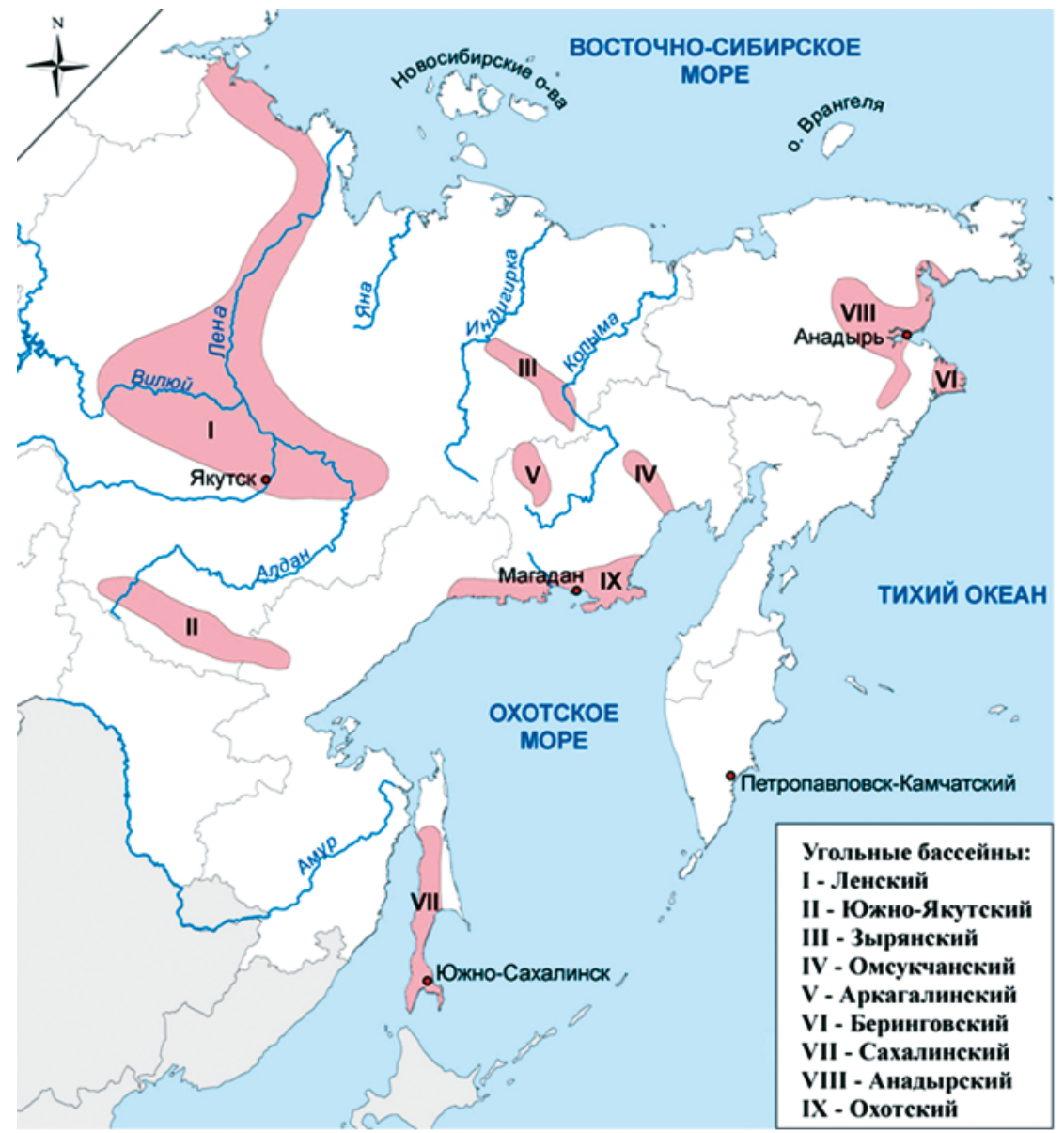

Рис. 1.1. Угольные бассейны Северо-Востока России (Угольная база ..., 1999) 


\section{С.И. Миронова, В.В. Иванов}

Во многих рудниках почти все виды работ выполнялись вручную. Даже бурение шпуров на угольном пласте производилось коловоротом с бурами, изготовленными из головок рельс. Откатка угля велась в самодельных деревянных вагонетках по брусчатке. Освещение шахт осуществлялось керосиновыми лампами «летучая мышь». Из-за отсутствия оборудования вентиляция выработок велась естественной тягой. Не хватало квалифицированных специалистов и рабочих. Бытовые условия проживания временных рабочих были крайне неблагоприятными. Например, на руднике «Джебарики-Хая» рабочие жили во временных сооружениях типа землянок, вырытых и обустроенных на одном берегу р. Алдан, а на смену рабочие добирались с помощью различных плавсредств через эту достаточно сложную водную преграду [3].

Только после войны началось внедрение механизации труда в угольных шахтах Якутии. С 1946 г. началось внедрение электросверл, были механизированы вентиляция выработок, заточка буров, проведено электрическое освещение штолен, появились вагонетки с роликовыми подшипниками, началась укладка рельс. В период с 1946 по 1950 годы была проведена определенная работа по техническому оснащению горных работ на угольных шахтах республики.

Значительный рост угледобычи на Северо-Востоке СССР произошел в результате создания региональных производственно-экономических структур - Советов экономического развития народного хозяйства (совнархозов) - Якутского и Магаданского. Повысилась механизация горных работ, основные угледобывающие предприятия были объединены в единый комплекс, действовавший в русле единой технической политики. В Сангарском шахтоуправлении в 1960 году вступила в эксплуатацию шахта «Центральная штольня», оснащенная угольными комбайнами и мощными электровозами, в «Джебарики-Хайском» шахтоуправлении были механизированы отбойка, доставка, транспортировка и выдача угля на поверхность, погрузка в баржи для доставки потребителям и т.д. Механизация труда в шахтах «Сангарская» и «Джебарики-Хая» позволило повысить годовой объем добычи до 360 и 290 тыс. т соответственно [3].

Особый этап в развитии угледобывающей промышленности на Северо-Востоке России, да и во всем Дальневосточном экономическом районе связан с освоением угленосного бассейна в Южной Якутии, которая до войны продолжала оставаться недостаточно исследованным регионом. Основная деятельность по разведке и промышленному освоению южно-якутских недр была связана с золотом, которое добывалось с XIX века старателями, артелями частными и государственными 
компаниями. Угленосность и содержание железорудных пород в регионе были изучены слабо. Территорию исследовали многочисленные отряды трестов «Алданзолото», «Востсибслюда», Восточно-Сибирского и Дальне-Восточного геологических управлений и других организаций. Итоги их работы были обобщены в трудах Ю.А. Билибина, В.Н. Зверева, Д.С. Коржинского, Ю.А. Дзевановского [1]. Благодаря им, а также исследованиям И.П. Атласова (1931 г.), А.И. Кукса и И.В. Белова (1938 г.), Е.П. Павловского (1939 г.), П.А. Харитонова и Е.М. Ковалева (1941 г.), Н.В. Фроловой (1944 г.), М.М. Одинцовой, М.И. Танеевой (1947 г.) и других, были намечены общие контуры Южноякутского каменноугольного месторождения от бассейна рек Олекмы, на западе, до Учура, на востоке, протяженностью 750 км (Акинин, 2016).

В 1951 г. при проведении съемочных работ на берегу р. Нерюнгра, геологи Г.Ю. Лагздина и О.А. Трещалова обнаруживают выходы на поверхность пластов угля - так был открыт пласт «Пятиметровый» будущего Нерюнгринского месторождения. В 1953 г. Л.М. Минкин обнаруживает в том же самом районе пласт «Мощный» [2].

К началу 60-х гг. XX в. ситуация, хотя и медленно, стала выправляться. Объемы и темпы добычи каменного угля на территории Якутии за 20 лет, с 1946 по 1965 гг, постоянно увеличивались. Постепенно уголь занял ведущее место в топливно-энергетическом балансе республики (Акинин, 2016).

В начале 80-х годов XX века на основе наиболее перспективных для разработки месторождений (доступность, себестоимость, транспортная инфраструктура, возможность экспорта и др.) Южно-Якутского каменноугольного бассейна, занимающего территорию 26,3 тыс. кв. км, было решено создание Южно-Якутского территориально-производственного комплекса (ЮЯ ТПК). Первенцем нового многоотраслевого ТПК являлся Южно-Якутский угольный комплекс, о строительстве которого 29 апреля 1975 г. ЦК КПСС и Совет Министров СССР приняли совместное Постановление за № 352 [3].

В результате огромной работы государственных органов, проектных учреждений, научно-исследовательских институтов, строительных и горных предприятий за короткий срок был разработан и реализован план строительства объектов Южно-Якутского УК, включающий разрез «Нерюнгринский», обогатительную фабрику, производственную базу, г. Нерюнгри, подъездную ж/д «Беркакит - Угольная», аэропорт и другие объекты районного и республиканского значения.

Разрез «Нерюнгринский» с 1976 года и по настоящее время является основным объектом угледобычи в Якутии. 


\section{С.И. Миронова, В.В. Иванов}

Южно-Якутский территориально-промышленный комплекс намечался как многоцелевой, с развитием в нем предприятий угольной промышленности, черной и цветной металлургии, производства минеральных удобрений и других отраслей. Но завершить его не удалось. Был сделан только первый шаг в этом направлении, создана топливная база - Южно-Якутский угольный комплекс (Акинин, 2016).

Группой «Мечел» реализуется проект строительства Эльгинского угольного комплекса в пределах Северо-Западного участка Эльгинского каменноугольного месторождения в Республике Саха (Якутия). В настоящее время ведется строительство Эльгинского горно-обогатительного комбината с проектной мощностью 28-30 млн тонн. Полностью уложен и ведутся работы по расширению пропускной способности железнодорожного подъездного пути Улак-Эльга протяженностью 335 км. Построены притрассовая автомобильная дорога от станции Улак до Эльгинского месторождения, вахтовый посёлок численностью до 3,0 тыс. человек и объекты энергоснабжения и инженерные сети.

ООО УК «Колмар» ведет поэтапное строительство 2 крупных горнообогатительных комплексов «Денисовский» и «Инаглинский».

ГОК «Денисовский» включает 2 шахты, один карьер и обогатительную фабрику мощностью 6 млн тонн/год.

Проект «Строительство ГОКа «Инаглинский»» включен в перечень приоритетных инвестиционных проектов, планируемых к реализации на территории Дальнего Востока (распоряжение Правительства РФ от 23 марта 2015 г. № 484-р), входит в ФЦП Российской Федерации «Экономическое и социальное развитие Дальнего Востока и Байкальского региона на период до 2018 года». Реализация проекта позволит довести годовую добычу на данном ГОКе до 29,7 млн т угля.

Дальнейшее развитие угледобычи в Южной Якутии связано с расширением экспорта коксующихся углей в страны АТР.

\section{Дитература}

1. Южноякутская угленосная площадь. Труды лаборатории геологии угля. Вып. ХІ. М.-Л., 1961. С. 32.

2. Почетные граждане Нерюнгри // Нерюнгринский район: история, культура, фольклор. Якутск, 2007. С. 345; Сергеев Ю. В. Указ. соч. С. 33.

3. МБУ Муниципальный архив Нерюнгринского района. Ф. 33. Оп. 1. Д. 1. Л. 1. 


\section{2. Особенности технологии добычи угдя}

\section{Характеристика выбросов Нерюнгринского разреза}

\subsection{1. Краткая характеристика предприятия}

Нерюнгринское каменноугольное месторождение, отрабатываемое в настоящее время разрезом «Нерюнгринский», находится в АлданоЧульманском угленосном районе Южно-Якутского угольного бассейна и своей южной частью примыкает к территории города Нерюнгри.

Разрез «Нерюнгринский» является структурной единицей по добыче угля ОАО ХК «Якутуголь» Министерства топлива и энергетики Республики Саха (Якутия). Разрабатываемое разрезом месторождение находится на территории, подчиненной администрации города Нерюнгри Республики Саха (Якутия).

Ближайшие к разрезу (месторождению) населенные пункты расположены: город угольщиков Нерюнгри и поселок энергетиков Серебряный Бор (Нерюнгринская ГРЭС) - в 6 и 20 км к востоку соответственно, поселок Чульман (Чульманская ГРЭС) - в 50 км к северу, поселок Беркакит (железнодорожная станция Беркакит) - в 20 км южнее разреза. В районе поселка Чульман имеется аэропорт города Нерюнгри, принимающий все типы современных самолетов. От железнодорожной станции Большой Невер (Транссибирская магистраль) до города Якутска, через поселки Беркакит, Чульман, Алдан и Томмот, проходит Амуро-Якутская автомагистраль (АЯМ).

Все населенные пункты и промплощадки разреза связаны между собой и с Амуро-Якутской автомагистралью шоссейными дорогами. Связь района Нерюнгринского месторождения с Транссибирской и БайкалоАмурской железнодорожными магистралями осуществляется по железной дороге БАМ - Тында - Беркакит и подъездному железнодорожному пути от основной промплощадки разреза «Нерюнгринский» до станции Беркакит. В настоящее время осуществляется строительство железнодорожной магистрали от станции Беркакит до города Якутска. Участок строящейся магистрали между станциями Беркакит - Чульман - Алдан - Томмот находится в промышленной эксплуатации.

Основными структурными подразделениями ОАО ХК «Якутуголь», обеспечивающими функционирование разреза «Нерюнгринский» по добыче угля являются: обогатительная фабрика «Нерюнгринская», погрузочно-транспортное управление (ПТУ), Нерюнгринская автобаза, Нерюнгринский ремонтно-механический завод (РМЗ) и другие. Добываемые на разрезе коксующиеся угли обогащаются на Нерюнгринской ОФ, 
энергетические угли транспортируются автотранспортом на комплекс погрузки энергетических углей (КПЭУ) при ОФ «Нерюнгринская» и на прирельсовый угольный склад № 1 разреза на монтажной площадке с погрузкой угля в железнодорожные вагоны экскаватором-мехлопатой. Отгружаются энергетические угли в рядовом виде: крупностью $0-50$ мм через КПЭУ; крупностью 0-300 мм с прирельсового склада № 1. В состав технологического комплекса разреза также входят: ремонтно-механический цех (РМЦ), участок подготовки производства (УПП), дренажный участок, комплекс по приготовлению шебня (в составе дорожно-строительного участка № 7), авто-тракторно-бульдозерный цех и склад ВМ. Административно-бытовое обслуживание трудящихся разреза осуществляется в АБК разреза, расположенном на главной промплощадке.

Энергетическая база района представлена Нерюнгринской и Чульманской ГРЭС - ТЭЦ мощностью 620 и 72 тыс. кВт, соответственно, которые посредством ЛЭП 110 кВ между собой и ЛЭП-220 кВ между Нерюнгринской и Зейской ГРЭС входят в состав единой энергетической системы. Топливом для ГРЭС-ТЭЦ являются, в основном, нерюнгринские энергетические угли и промпродукт нерюнгринской обогатительной фабрики. От НГРЭС по ВЛ- 110 кВ на металлических опорах осуществляется питание ПС 110/35/7 кВ № 40, а от последней - питание объектов разреза «Нерюнгринский».

Теплоснабжение объектов разреза, ОФ и все промышленной зоны осуществляется также от Нерюнгринской ГРЭС - ТЭЦ по магистральной теплотрассе теплоносителем перегретая вода с максимальными параметрами $150-70^{\circ} \mathrm{C}$.

Источником хозяйственно-питьевого водоснабжения объектов разреза является районный водопровод, по которому вода поступает на главную промплощадку разреза и далее по местным сетям водопровода распределяется по промплощадкам и объектам технологических комплексов разреза и ОФ и автобазы технологического автотранспорта.

Бытовые стоки от объектов ОФ и разреза отводятся через сети главной промплощадки разреза и ОФ в систему районной канализации (сети канализации, перекачивающие и подкачивающие насосные станции и очистные сооружения).

На Нерюнгринском месторождении непосредственно изучены только отложения нерюнгринской $\left(\mathrm{J}_{3} \mathrm{nr}\right)$ и холодниканской $\left(\mathrm{K}_{1} \mathrm{ch}\right)$ свит верхнеюрского и нижнемелового возрастов.

Отложения Нерюнгринской свиты вскрыты на всей площади месторождения буровыми скважинами на 10-30 м. ниже пласта Пятиметрового и, в большинстве случаев, 15-20 м. ниже пласта Мощного, который 
венчает ее разрез. Свита имеет высокую промышленную угленосность. Она содержит пласт Мощный, пласт Пятиметровый, пласт Неожиданный и два Промежуточных пласта, залегающих между Пятиметровым и Мощным.

Промышленный интерес имеют два угольных пласта рабочей мощности - пласты Мощный и Пятиметровый.

Пласт Мощный является основным объектом эксплуатации разрезом «Нерюнгринский». Он разрабатывается с 1979 г. Площадь его распространения составляет 16 км²$^{2}$, максимальная глубина погружения 315 м; на крыльях Нерюнгринской мульды пласт выходит на дневную поверхность. По материалам разведочных работ пласт Мощный на площади месторождения характеризуется значительными колебаниями мощностей - от 1,40 до 79,15 м. В южной части месторождения он расслаивается на 2-3 пачки и уменьшается в мощности. Среднее значение мощности угольного пласта по всем пластопересечениям вне зоны расщепления составляет 24,82 м. В северо-западной части месторождения в первом тектоническом блоке мощность пласта колеблется от 14,82 до 35,75 м. Здесь пласт характеризуется, преимущественно, сложным строением. По данным доразведки в разрезе пласта установлено от 5 до 10 прослоев высокозольного угля, углистых алевролитов и песчаников. На площади второго, третьего и четвертого тектонических блоков пласт представляет собой залежь с ровной поверхностью кровли и с неровной валообразно изменяющейся почвой. Общая тенденция залежи - постепенное уменьшение мощности пласта в южном направлении. Мощность пласта изменяется от 43-46 м. на севере до 1,40 на юге, хотя максимальные значения мощности находятся в южной части второго тектонического блока. Участки пласта большой мощности постепенно или очень резко сменяются участками с пониженной мощностью. Особое положение занимает восточная часть блока. В северной части этого участка в восточном направлении мощность пласта изменяется от 43-46 м. до $3,65-7,90$ м. на расстоянии менее, чем в 50 м. В юго-восточном и южном направлениях мощность возрастает до 11-15 м. Далее на юг пласт представляет собой залежь с резко расщепленной почвой, когда амплитуда колебаний мощности на отдельных участках достигает более 50 м. Здесь же отмечены максимальные для месторождения значения мощности пласта Мощного - 79,15 м. Участок характеризуется наличием мощных раздувов и утонений пласта, внутриформационных перерывов, явлений местных расщеплений. Здесь же общая мощность угольной залежи является максимальной и достигает 140 метров, однако, между верхней и нижней пачками угля залегает мощная линза песчаников с редкими до 1,45 м прослоями угля. Ширина этой линзы составляет 300 м. Южнее ее 
западное замыкание не установлено. В восточном направлении она резко обрывается, сменяясь мощной пачкой угля. Максимальная мощность линзы песчаника составляет $100 \mathrm{M}$.

Почва пласта Мощного на изученных участках месторождения сложена серыми мелкозернистыми песчаниками с пологоволнистой и мелкой косой слоистостью. У контакта с углем песчаник часто обогащен тонко рассеянным углистым материалом и содержит обугленные остатки растений.

При рассмотрении разреза пласта Мощного отмечается хорошо выраженная последовательность смены петрографических типов углей от блестящих к полуматовым и матовым. Согласно этой смене и происходит увеличение зольности угля при переходе от нижних слоев к верхним.

В южной части месторождения, как указывалось выше пласт Мощный расщепляется на три пачки - верхнюю, среднюю (основную) и нижнюю. Площадь из распространения составляет около 3 км².

Верхняя пачка отщепляется от основной в юго-восточной части месторождения. Строение пачки сложное, обычно она содержит 2-3, реже 4-6 породных прослоя представленных углистыми песчаниками, углистыми алевролитами не выдержанных по простиранию, мощность которых изменяется от 0,10 до 0,50 м. Мощность пачки изменяется от 0,70 до 9,22 м. Увеличение мощности происходит постепенно на восток, от линии отщепления на западе, причем примерно на половину площади распространения верхней пачки мощность пласта не достигает рабочего значения. Далее на восток и северо-восток некондиционное значение мощности отмечено только в одной скважине. Рабочее значение мощности изменяется от 2,10 до 9,22 м, составляя в среднем 4,79 метров.

Основная пачка представляет собой относительно устойчивый угольный пласт на большей части своего распространения сохраняющий рабочее значение. Строение пачки в большинстве пластопересечений простое, однако, в ее разрезе очень часто встречаются 2-3 прослоя углистых алевролитов или песчаников мощностью $0,10-0,70$ м и редко она содержит до 14 прослоев углистых пород мощностью 0,5-0,15 метров. В пространстве эти породные прослои не коррелируются, не установлено закономерности в приуроченности их какой-либо части в разрезе пласта. Из 116 пластопересечений только 10 показывают некондиционное значение мощности. Эти мощности приурочены к южной центральной части площади и наблюдаются в пределах 0,50-1,65 м. По другим 106 пластопересечениям мощность пласта изменяется от 2,07 до 28,26 м, составляя в среднем 11,03 метра. Наиболее встречаемые мощности составляют 9-13 метров. Пониженные значения мощности (2-3 м) 
приурочены, главным образом, к северной границе площади распространения пласта с некондиционной мощностью, а на остальной части встречаются редко, хотя и имеют место. Обращают внимание резкие колебания в значениях мощности пачки. Причем эти изменения происходят на коротких расстояниях и, как и в северной части месторождения, в основном со стороны почвы пласта.

Нижняя пачка представляет собой неустойчивый угольный пласт, который на значительной площади своего распространения имеет мощность ниже кондиционной или вообще отсутствует. Отчетливо выделяются два участка с наиболее устойчивыми значениями рабочих мощностей. На этих участках наиболее встречаемая мощность составляет 4-6 - 10 метров, достигая в отдельных случаях более 16-18 м. Вдоль всей северной границы участка расщепления мощности составляют $2,5-5,0$ метров. Для центральной части участка и всей его южной границы характерны мощности ниже 2,0 м. Значение рабочей мощности для всей площади участка составляет по 71 пластопересечению от 2,0 до 18,36 метров, при среднем значении 5,24 м. Строение пачки в основном простое. Редко она содержит 1-2 породных прослоя мощностью $0,10-0,25$ метров представленных углистыми алевролитами или песчаниками невыдержанными по простиранию.

Другим перспективным пластом на месторождении является пласт «Пятиметровый», который имеет рабочую мощность на значительной площади своего распространения и залегает в 100-120 м ниже почвы пласта Мощного. Средняя подсчетная мощность пласта составляет 3,62 метра. По петрографическому составу уголь пласта Пятиметрового сходен с углем нижнего комплекса пл. Мощного. Он представлен преимущественно блестящими и полублестящими углями. Зольность угля изменяется от 10 до $30 \%$. В кровле пласта залегают разнообразные по литологическому составу породы - от аргиллитов до крупнозернистых песчаников. В почве пласта - песчано-алевролитовые и глинисто-углистые осадки пойм. Анализ мощностей и строения пласта показывает, что пласт сложную морфологию. Наибольшее колебание мощностей пласт испытывает в северо-западной части месторождения. Мощность здесь колеблется в пределах 2-10 м, достигая в отдельных точках до 21,38 метров. В южной части месторождения пласт значительно утрачивает свое промышленное значение ввиду небольших, невыдержанных мощностей и частым наличием участков полного выклинивания пласта. В итоге, анализируя все имеющиеся данные по характеристике пласта Пятиметрового, можно, с определенной долей уверенности, сказать, что пласт представляет собой единую угольную залежь. 
При бурении скважин на пл. Пятиметровом в ряде скважин встречены угольные пласты, имеющие мощность 1 м и более, которые являются невыдержанными по мощности, строению, и площадному развитию, что позволяет предположить о бесперспективности этой части толщи. Ниже пласта Пятиметрового практический интерес может представлять лишь пласт Неожиданный, вскрытый единичными скважинами. Мощность его колеблется от нерабочей до 4-5 метров. Площадное распространение пласта не выяснено.

Характеристика угольных пластов приведена в табл. 1.1.

Таблица 1.1

\begin{tabular}{|c|c|c|c|c|c|c|c|}
\hline \multirow{2}{*}{$\begin{array}{c}\text { № } \\
\text { П/П }\end{array}$} & \multirow{2}{*}{$\begin{array}{c}\text { Название } \\
\text { пластов }\end{array}$} & \multirow{2}{*}{$\begin{array}{c}\text { Пло- } \\
\text { щадь } \\
\text { распро- } \\
\text { стране- } \\
\text { ния, км² }\end{array}$} & \multirow{2}{*}{$\begin{array}{c}\text { Рас- } \\
\text { стояние } \\
\text { между } \\
\text { пласта- } \\
\text { ми, м }\end{array}$} & \multicolumn{3}{|c|}{$\begin{array}{c}\text { Мощность пластов, } \\
\text { м }\end{array}$} & \multirow{2}{*}{$\begin{array}{c}\text { Степень } \\
\text { устойчивости }\end{array}$} \\
\hline & & & & от & до & $\begin{array}{c}\text { сред- } \\
\text { няя }\end{array}$ & \\
\hline 1 & Мощный & 13 & $100-120$ & 2,0 & 79,15 & 27,23 & отн. устойчив. \\
\hline 2 & Пятиметровый & & & 2,00 & 21,0 & 3,62 & отн. устойчив. \\
\hline 3 & Верхняя пачка & 3 & $20-30$ & 2,10 & 9,22 & 5,85 & неустойчив. \\
\hline 4 & Основная пачка & 3 & $30-40$ & 2,07 & 28,26 & 12,20 & отн. устойчив. \\
\hline 5 & Нижняя пачка & 3 & & 2,0 & 18,36 & 6,64 & неустойчив. \\
\hline
\end{tabular}

Вмещающие вскрышные породы представлены, в основном крупно-, средне- и мелкозернистыми песчаниками кварц-полевошпатового состава, в незначительном количестве - алевролитами, аргиллитами, гравелитами и конгломератами высокой литификации.

Встречаемость разностей литологических типов пород приведена в табл. 1.2.

Таблица 1.2

\begin{tabular}{|c|l|c|}
\hline $\begin{array}{c}\text { № } \\
\text { п/п }\end{array}$ & \multicolumn{1}{|c|}{ Литологический тип пород } & $\%$ \\
\hline 1 & Гравелиты и конгломераты & 3,3 \\
\hline 2 & Крупнозернистые песчаники & 21,8 \\
\hline 3 & Среднезернистые песчаники & 26,3 \\
\hline 4 & Мелкозернистые песчаники & 31,6 \\
\hline 6 & Алевролиты & 16,7 \\
\hline 7 & Угли & 0,3 \\
\hline
\end{tabular}


Четвертичные отложения, представлены песками и галечниками мощностью 1,0-3,0 м и распространены повсеместно. Удельный вес вскрышных пород изменяется от 2,62 до 2,84 г/ $\mathrm{cm}^{3}$, объемный вес - от 2,44 до

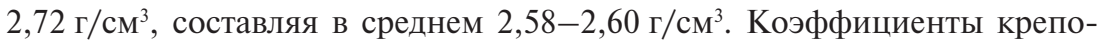
сти основных пород вскрыши (песчаников) по шкале проф. М.М. Протодьяконова изменяются от 6,6 у тонкозернистых песчаников до 10,1 - у крупнозернистых. Породы, сложенные разнозернистыми песчаниками, относятся к породам средней, выше средней и повышенной абразивности. Трещиноватость вскрышных пород и угля - высокая.

Все вскрышные породы содержат до 40-60\% свободной окиси кремния и относятся к силикозоопасным.

Вскрышные породы в связи с высоким содержанием в них кварца (45-70\%) относятся к породам средней, выше средней и повышенной абразивности.

Уголь месторождения сильно деформирован тектоническими процессами, подвержен многократному смерзанию и оттаиванию и, как следствие отличается исключительной хрупкостью, легкой дробимостью и повышенной склонностью к пылеобразованию при отработке после осушения.

В целом породы вскрыши классифицируются как крепкие, редко довольно крепкие (угли довольно мягкие), преимущественно выше средней абразивности, реже малоабразивные, средне - крупноблочные, сейсмически жесткие, при отработке требуют сплошного рыхления взрывными работами. Угли в отдельных случаях требуют частичного применения БВР.

Породы на площади месторождения по степени устойчивости в откосах разреза относятся:

1. В зоне выветривания - ко II группе 2-й подгруппы как скальные выветрелые породы повышенной трещиноватости средней крепости;

2. Вне зоны выветривания - к I группе 2-й подгруппы - крепкие скальные породы осложненные рядом пликативных и дизъюнктивных нарушений, иногда со значительным перемещением пород.

С точки зрения предельно равновесного состояния породы откосов имеют значительный запас прочности и классифицируются как весьма устойчивые.

В процессе эксплуатации разреза возможны следующие деформации уступов.

Обрушения по контактам, тектоническим нарушениям, отдельным трещинам падающим навстречу фронту работ под углами круче $25-30^{\circ}$. Для предотвращения обрушений необходима заоткоска уступов не круче углов падения сместителей, т.е. менее $70^{\circ}$. На участках, где падение 
напластования пород направлено в сторону выработанного пространства возможна деформация всего уступа.

Осыпания уступов вследствии выветривания, промерзания и протаивания, интенсивной трещиноватости, массовых взрывов, отсутствия оптимальной заоткоски.

Провалы и оседания площадок рабочих уступов вызванные интенсивной тектонической нарушенностью пород участка и изменением температурного режима мерзлых горных пород в процессе ведения вскрышных работ летом.

Рекомендуемые углы откосов рабочих уступов при высоте 15-20 м, с учетом опыта ведения горных работ в зоне выветривания составляют $65-70^{\circ}$, ниже зоны выветривания $-75^{\circ}$. Углы наклона нерабочих уступов $-60^{\circ}$.

Ориентировочные углы наклона рабочих бортов с учетом размера рабочих площадок 50-60 м - 30-35. У Улы наклонов угольных уступов при высоте $10 \mathrm{~m}-60^{\circ}$.

Отвалам из пород вскрыши отсыпаемых под углом естественного откоса на прочное основание может быть придана практически неограниченная высота без нарушения устойчивого равновесия.

Многолетнемерзлые породы на месторождении слагают большую часть его площади (70-80\%). Наименьшая мощность многолетнемерзлых (до 50 м) отмечается в южной части, наибольшая (150-160 м) - на склонах долины безымянного ручья - притока р. Н. Нерюнгра.

Температура горных пород в пределах распространения мерзлых пород на глубине 10 м достигает $-4,2^{\circ} \mathrm{C}$, средняя температура на этой глубине составляет $-1,29^{\circ} \mathrm{C}$. Мощность слоя сезонных колебаний температур достигает $25-20 \mathrm{M}$, геотермическая ступень $-95 \mathrm{M} /{ }^{\circ} \mathrm{C}$, температурный градиент $-0,01^{\circ} \mathrm{C} / \mathrm{M}$.

Талые породы отмечаются на небольших участках, располагающихся в верхних частях водораздела и вдоль русла р. В. Нерюнгра. Установлено, что таликовая зона в северо-восточной части не имеет сплошного распространения, а ее западная граница отодвинулась гипсометрически до отметки 950 м и проходит узкой полосой в верхней части водораздела p. В. Нерюнгра и руч. Холодникан с северо-запада на юго-восток.

Кроме того, таликовые зоны отмечаются еще на трех небольших участках, располагающихся также в верхней части водораздела, на южных склонах р. В. Нерюнгри и в районе скважины № 1509.

Талики водоразделов имеют снежногенно-инфильтрационную природу возникновения.

Почвы в районе месторождения преобладают подзолистого и болотного типа, имеющие невысокое плодородие. Почвообразующими 
породами являются продукты выветривания безкарбонатных кристаллических пород - песчаников, алевролитов и аргиллитов. селективное отвалообразование при одинаковых физико-механических свойствах вскрышных пород разреза и мелкоземов почвенного покрова нецелесообразно; также нецелесообразно снятие растительного слоя для использования в сельскохозяйственных целях из-за его непригодности.

Работы по изучению газоносности углей и пород Нерюнгринского месторождения проводились до 1975 года Южно-Якутской комплексной экспедицией, а с 1975 года Нерюнгринской геологоразведочной партией треста «Дальвостуглеразведка».

В угленосной толще месторождения установлены: метан, тяжелые углеводороды, водород, углекислый газ и азот. Образование природных газов связано с региональным, регионально-термальным метаморфизмом, окислительными процессами. При изучении состава газа угленосной толщи месторождения установлены три основные зоны: метановоазотных, азотно-метановых и метановых газов. В связи с отсутствием на месторождении зоны полной деметанизации зоны углекисло-азотных и азотно-углекислых не выделены. Природные газы в угольной толще Нерюнгринского месторождения представлены в основном метаном. Газоносность угольных пластов не превышает по водороду $0,1 \mathrm{~m}^{3} /$ т сбм; углекислому газу $-0,8 \mathrm{~m}^{3} /$ т сбм. Поэтому основное внимание в настоящем разделе уделяется метану и метаноносности угольных пластов и вмещающих пород.

Метаноносность угольных пластов изменяется от 0,001 до $10,14 \mathrm{~m}^{3} / \mathrm{T}$ сбм. метаноносность пласта Мощного - от 0,001 до 8,63 м³/т сбм. Максимальные значения отмечены в осевой части брахисинклинали на глубине 280 м. Метаноносность пласта Пятиметрового изменяется от 0,11 до 10,14 м³ $/$ с сбм; максимальные значения наблюдаются на глубине 310 м.

В пределах месторождения отмечается закономерное увеличение метаноносности угольных пластов с глубиной их залегания. Так, на глубине 100 м средняя метаноносность пластов составляет $1,5 \mathrm{~m}^{3} /$ т сбм; $200 \mathrm{м}-$ $2-3,5 \mathrm{~m}^{3} /$ т сбм; $300 \mathrm{м}-5,0-5,8 \mathrm{~m}^{3} /$ т сбм; $350 \mathrm{м}-6,2-7,0 \mathrm{~m}^{3} /$ т сбм.

На месторождении по характеру распределения метана в угольной толще выделяются три основные части: северо-западная, центральная и южная.

Северо-западная часть характеризуется изменчивой мощностью зоны газового выветривания, метаноносность пластов изменяется от 0,01 до 3,7 м³ т сбм. по пласту Мощному и от 1,2 до 10,1 м³ $/$ т сбм по пласту Пятиметровому.

Центральная часть месторождения характеризуется повышенными значениями метаноносности угольных пластов до 8-9 м³ 
Мощному. Метаноносность пласта Пятиметрового в этой части не изучена. Мощность газового выветривания относительна стабильна.

С увеличением залегания пластов происходит закономерное нарастание метаноносности до $9 \mathrm{~m}^{3} /$ т сбм в осевой части складки.

Южная часть месторождения характеризуется пониженными содержаниями метана в угольных пластах $(0,0-17,0 \%)$ и метаноносностью $0,0-0,8$ м $^{3} /$ с сбм на глубинах $80-180$ м от поверхности.

Метаноносность вмещающих пород незначительна и изменяется от 0,06 до $0,28 \mathrm{~m}^{3} / \mathrm{T}$ и составляя в среднем $0,12 \mathrm{~m}^{3} /$ т.

Подсчет запасов метана согласно «Временных методических требований геолого-экономической оценке и подсчету запасов метана в угольных пластах» не производился, так как Метаноносность угольных пластов менее $10 \mathrm{M}^{3} /$ т сбм.

Современная газоносность угленосной толщи зависит от влияния следующих геологических факторов: тектоники, глубины залегания угольных пластов, метаморфизма, угленосности, гидрогеологических и геокриологических условий, характера перекрывающих отложений и других.

Границей разреза является выход пласта Мощного под четвертичные отложения по периметру брахисинклинальной складки. В контуре выхода на поверхность пласта Мощного брахисинклиналь прослеживается в направлении с северо-запада на юго-восток на расстоянии 6,15 км при максимальной ширине 3,9 км. Площадь месторождения составляет

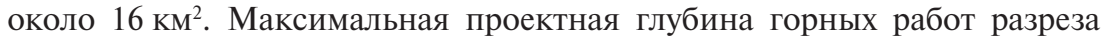
(глубина погружения почвы пласта Мощного по оси складки) до 400 м (абс. отм. +550 м). По состоянию на 01.01.03 года фактические отметки горных работ по пласту на горных участках западного крыла составили +605 м, восточного крыла $-+768,0$ м.

Подсчет запасов угля произведен согласно постоянным кондициям, разработанными институтом «Сибгипрошахт», которые утверждены протоколом ГКЗ СССР № 765 от 7 декабря 1973 г.:

- минимальная мощность угольных пачек пласта Мощного простого и сложного строения -2 м;

- максимальная мощность отдельных породных прослоев, отрабатываемых валом и включаемых в подсчет запасов по угольной массе -2 м;

- максимальная зольность $\left(\mathrm{A}^{\mathrm{c}}\right)$ угольного пласта с учетом $100 \%$ засорения породой $-35 \%$.

При утверждении запасов угля по месторождению (сводный геологический отчет по Нерюнгринскому месторождению, протокол ГКЗ № 10545 от 25.11.1988 г.) балансовые запасы по категориям $\mathrm{A}+\mathrm{B}+\mathrm{C}_{1}$ составили 365700 тыс. тонн. 
Сравнение утвержденных протоколом ГКЗ и оставшихся балансовых запасов углей пласта Мощного в границах разреза по состоянию на 01.01.03 г. показано в табл. 1.3.

Таблица 1.3

\begin{tabular}{|l|c|c|c|c|}
\hline \multirow{2}{*}{$\begin{array}{c}\text { Техноло- } \\
\text { гическая } \\
\text { группа }\end{array}$} & $\begin{array}{c}\text { Запасы, утвержден- } \\
\text { ные протоколом }\end{array}$ & \multicolumn{2}{|c|}{ Остаток запасов по состоянию на 01.01.2003 г. } \\
\cline { 3 - 5 } & Гт 25.11.1988 г. & $\begin{array}{c}\text { По статистиче- } \\
\text { ской отчетности } \\
\text { (Форма 5-гр) }\end{array}$ & $\begin{array}{c}\text { По пересчету } \\
\text { ГУП «НГРП» }\end{array}$ & $\begin{array}{c}\text { По расчету } \\
\text { ОАО «Сиб- } \\
\text { гипрошахт» }\end{array}$ \\
\hline 3 СС & 87996,0 & 25510,0 & 25591,2 & 25545,7 \\
\hline $\mathrm{K}_{6}$ & 49960,0 & 44333,0 & 45687,1 & 45508,1 \\
\hline $\mathrm{K}_{9}$ & 227744,0 & 150232,0 & 157543,5 & 158789,2 \\
\hline Всего & 365700,0 & 220075,0 & 228821,8 & 229843,0 \\
\hline
\end{tabular}

В соответствии с принятой системой разработки отработка угольного пласта Мощный осушествляется слоями мощностью по 10 м с погрузкой в автомобильный транспорт.

Отработка угольного пласта принята селективная, в соответствии с утвержденным в 1987 году пересмотром технического проекта, в котором был произведен анализ горно-геологических условий залегания пласта.

Породоугольная смесь от зачистки угольного пласта при его отработке вывозится и складируется на вскрышных внешних и внутренних отвалах.

\subsection{2. Основные источники выбросов на разрезе}

В Нерюнгринском районе расположены 82 предприятия, деятельность которых связана с выбросами в атмосферу. Основными источниками загрязнения воздуха различными веществами являются объекты угольной промышленности, теплоэнергетики, старательские артели и железнодорожный и автомобильный транспорт.

В табл. 1.4 приведены суммарные показатели выбросов загрязняющих веществ по территории административного подчинения г. Нерюнгри в различные годы, а в табл. 1.5 - характеристика выбросов по населенным пунктам.

Приведенные данные (Отчет, 2001) показывают, что объем выбросов по годам практически остается на одном уровне. Необходимо иметь в виду, что контроль ведется в очень узком диапазоне, некоторые опасные вещества не учитываются, нет данных по микроэлементному составу твердых частиц. 
Таблица 1.4 Выбросы в атмосферу по территории Нерюнгринского улуса

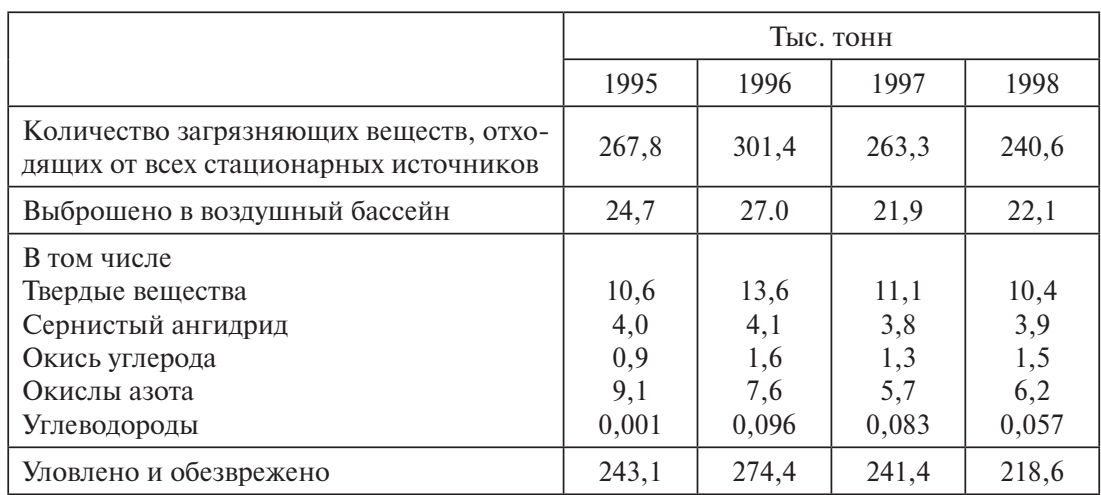

Таблица 1.5 Выбросы загрязняющих веществ по населенным пунктам Нерюнгринского улуса (тыс. т)

\begin{tabular}{|c|c|c|c|c|c|c|c|}
\hline \multirow{2}{*}{$\begin{array}{c}\text { Населенный пункт } \\
\text { с количеством } \\
\text { предприятий, ис- } \\
\text { точников выбросов }\end{array}$} & \multirow[b]{2}{*}{ Всего } & \multicolumn{5}{|c|}{ В том числе: } & \multirow{2}{*}{$\begin{array}{c}\text { Снижение (-), } \\
\text { увеличение (+) } \\
\text { к предыдущим } \\
\text { годам }\end{array}$} \\
\hline & & $\begin{array}{c}\text { Твер- } \\
\text { дые }\end{array}$ & $\mathrm{SO}_{2}$ & $\mathrm{CO}$ & $\mathrm{NO}_{x}$ & $\begin{array}{c}\mathrm{CH}, \\
\text { про- } \\
\text { чие }\end{array}$ & \\
\hline 1 & 2 & 3 & 4 & 5 & 6 & 7 & 8 \\
\hline $\begin{array}{c}\text { г. Нерюнгри } \\
\text { (20) } 1997 \text { г. } \\
(40) 1998 \text { г. } \\
(29) 1999 \text { г. } \\
2000 \text { г. } \\
2001 \text { г. } \\
2002 \text { г. } \\
2003 \text { г. } \\
2004 \text { г. }\end{array}$ & $\begin{array}{l}7,57 \\
6,769 \\
7,683 \\
9,592 \\
9,010 \\
8,730 \\
8,281 \\
8,281\end{array}$ & $\begin{array}{c}5,92 \\
5,222 \\
5,151 \\
4,435 \\
3,824 \\
4,085 \\
4,079 \\
4,241\end{array}$ & $\begin{array}{l}0,209 \\
0,222 \\
0,250 \\
0,272 \\
0,229 \\
0,176 \\
0,239 \\
0,262\end{array}$ & $\begin{array}{l}0,811 \\
0,664 \\
0,878 \\
2,749 \\
2,667 \\
2,513 \\
2,236 \\
2,462\end{array}$ & $\begin{array}{l}0,619 \\
0,640 \\
1,384 \\
1,629 \\
1,768 \\
1,465 \\
1,395 \\
1,811\end{array}$ & $\begin{array}{l}0,011 \\
0,021 \\
0,020 \\
0,507 \\
0,522 \\
0,491 \\
0,332 \\
0,322\end{array}$ & $\begin{array}{c}-8,89 \\
-0,804 \\
+0,914 \\
+1,909 \\
-0,582 \\
-0,28 \\
-0,449 \\
0\end{array}$ \\
\hline $\begin{array}{c}\text { п. Серебряный бор } \\
\text { (3) } 1997 \text { г. } \\
\text { (9) } 1998 \text { г. } \\
\text { (7) } 1999 \text { г. } \\
2000 \text { г. } \\
2001 \text { г. } \\
2002 \text { г. } \\
2003 \text { г. } \\
2004 \text { г. }\end{array}$ & $\begin{array}{c}12,19 \\
10,26 \\
10,207 \\
11,251 \\
12,461 \\
13,298 \\
14,013 \\
14,391\end{array}$ & $\begin{array}{c}5,09 \\
4,045 \\
4,611 \\
4,701 \\
4,307 \\
5,434 \\
5,178 \\
5,428\end{array}$ & $\begin{array}{c}3,04 \\
3,0 \\
2,567 \\
2,824 \\
3,724 \\
3,038 \\
3,603 \\
3,636\end{array}$ & $\begin{array}{c}0,01 \\
0,004 \\
0,023 \\
0,243 \\
0,288 \\
0,302 \\
0,261 \\
0,27\end{array}$ & $\begin{array}{c}4,06 \\
3,210 \\
2,9873 \\
3,422 \\
4,078 \\
4,455 \\
4,911 \\
5,003\end{array}$ & $\begin{array}{l}0,001 \\
0,018 \\
0,061 \\
0,064 \\
0,069 \\
0,058 \\
0,054\end{array}$ & $\begin{array}{c}-2,64 \\
-1,938 \\
-0,053 \\
+1,044 \\
+1,21 \\
+0,837 \\
+0,715 \\
+0,378\end{array}$ \\
\hline
\end{tabular}


Окончание табл. 1.5

\begin{tabular}{|c|c|c|c|c|c|c|c|}
\hline 1 & 2 & 3 & 4 & 5 & 6 & 7 & 8 \\
\hline п. Чульман & & & & & & & \\
(6) 1997 г. & 2,65 & 1,04 & 0,469 & 0,361 & 0,782 & 0,052 & 0,547 \\
(8) 1998 г. & 2,711 & 0,906 & 0,430 & 0,406 & 0,916 & 0,042 & $+0,062$ \\
(8) 1999 г. & 2,695 & 1,097 & 0,493 & 0,245 & 0,818 & 0,042 & $-0,016$ \\
2000 г. & 3,076 & 1,251 & 0,516 & 0,588 & 0,579 & 0,142 & $+0,381$ \\
2001 г. & 2,564 & 0,998 & 0,356 & 0,367 & 0,721 & 0,122 & $-0,512$ \\
2002 г. & 2,321 & 1,056 & 0,292 & 0,362 & 0,482 & 0,129 & $-0,243$ \\
2003 г. & 2,481 & 1,195 & 0,340 & 0,321 & 0,518 & 0,107 & $+0,16$ \\
2004 г. & 2,82 & 1,375 & 0,374 & 0,425 & 0,536 & 0,131 & $+0,339$ \\
\hline
\end{tabular}

Наиболее крупными источниками выбросов являются Нерюнгринский угольный разрез, обогатительная фабрика, Нерюнгринская и Чульманская ГРЭС и установка для очистки вагонов на железнодорожной станции Беркакит.

Нерюнгринский угольный разрез является крупным источником выбросов различных загрязняющих веществ на территории «Нерюнгринского производственного комплекса». При этом практически, все источники выбросов разреза относятся к неорганизованным.

Таблица 1.6

Основные источники и виды загрязнения на Нерюнгринском угольном разрезе

\begin{tabular}{|l|l|}
\hline $\begin{array}{l}\text { Основные технологиче- } \\
\text { ские процессы и объекты }\end{array}$ & \multicolumn{1}{|c|}{ Источники и виды загрязнения } \\
\hline \multicolumn{1}{|c|}{1} & \multicolumn{1}{|c|}{2} \\
\hline $\begin{array}{l}\text { Подготовка горных пород } \\
\text { к выемке }\end{array}$ & $\begin{array}{l}\text { Пыль и газы при бурении скважин и шпуров. } \\
\text { Пыль и ядовитые газы при производстве взрывных } \\
\text { работ }\end{array}$ \\
\hline $\begin{array}{l}\text { Выемочно-погрузочные } \\
\text { работы }\end{array}$ & $\begin{array}{l}\text { Пыль при выемке и погрузке горной массы в транс- } \\
\text { портные средства и разгрузке в отвал различными } \\
\text { выемочными машинами. } \\
\text { Пыль и газы при выемке горной массы экскавацион- } \\
\text { ными и экскавационно-транспортирующими маши- } \\
\text { нами с двигателями внутреннего сгорания (экскава- } \\
\text { торы с дизельными приводом, погрузчики, скреперы, } \\
\text { бульдозеры и т.д.) }\end{array}$ \\
\hline
\end{tabular}


Окончание табл. 1.6

\begin{tabular}{|c|c|}
\hline 1 & 2 \\
\hline $\begin{array}{l}\text { Транспортирование } \\
\text { карьерных грузов }\end{array}$ & $\begin{array}{l}\text { Пыль на карьерных автодорогах. } \\
\text { Сдувание пыли из транспортных сосудов при переме- } \\
\text { щении полезных ископаемых, пустых пород и отходов } \\
\text { обогащения. Пыль на пунктах перегрузки. } \\
\text { Газы при работе автотранспортных средств и тяговых } \\
\text { средств железнодорожного транспорта с двигателями } \\
\text { внутреннего сгорания }\end{array}$ \\
\hline $\begin{array}{l}\text { Отвалообразование } \\
\text { и складирование пустых } \\
\text { пород, отходов обогаще- } \\
\text { ния и полезных ископа- } \\
\text { емых }\end{array}$ & $\begin{array}{l}\text { Пыль при укладке горной массы в отвалы и склады. } \\
\text { Пыление обнаженных поверхностей отвалов пустых по- } \\
\text { род, складов полезных ископаемых, шламохранилищ. } \\
\text { Газы при самовозгорании горной массы в отвалах и на } \\
\text { складах }\end{array}$ \\
\hline Карьерные выемки & $\begin{array}{l}\text { Сдувание пыли с поверхностей откосов и площадок. } \\
\text { Выделение газов при самовозгорании полезных ис- } \\
\text { копаемых }\end{array}$ \\
\hline $\begin{array}{l}\text { Объекты промплощадки: } \\
\text { - дробильно-сортиро- } \\
\text { вочные, агломерацион- } \\
\text { ные и обогатительные } \\
\text { фабрики } \\
\text { - котельные установки } \\
\text { - базы производственных } \\
\text { машин и автотракторной } \\
\text { техники }\end{array}$ & $\begin{array}{l}\text { Пыль при разгрузке, дроблении и сортировке полезных } \\
\text { ископаемых. } \\
\text { Пыль и газы при обжиге и обогащении полезных ис- } \\
\text { копаемых. } \\
\text { Пыль и газы при работе котельных установок. } \\
\text { Газы и пыль при эксплуатации баз производственных } \\
\text { машин и автотракторной техники }\end{array}$ \\
\hline
\end{tabular}

\section{Постоянно действующие неорганизованные источники разреза}

Постоянно действующими неорганизованными источниками являются вскрышные и добычные работы по разрезу, а также источники горно-транспортной части разреза.

Выбросы вредных веществ осуществляют автосамосвалы и бульдозеры на добычных и вскрышных работах при сжигании топлива в двигателях внутреннего сгорания. От складов угля, в процессе бурения скважин, при движении автосамосвалов по технологическим дорогам и на отвалообразовании происходят выбросы пыли.

В воздух попадают загрязняющие вещества от топливозаправщика.

Периодические неорганизованные источники разреза

Одним из основных источников мгновенного выделения в атмосферу карьеров пыли и вредных газов являются массовые взрывы. 
Большинство вредных примесей, образовавшихся при взрыве, выбрасывается в атмосферу карьера с пылегазовым облаком, которое, развиваясь, достигает значительной высоты (до 1,5-1,6 км) и распространяется в атмосфере на расстояние от 8 до 12 км. При этом пылегазовое облако загрязняет окружающую воздушную среду и прилегающую к карьеру значительную территорию. Степень загрязнения зависит от начальной концентрации пыли и вредных газов в облаке.. Промышленные исследования дальности распространения пылегазового облака показывают, что на расстояниях, значительно превышающих санитарно-защитные зоны, концентрация пыли в несколько раз превышает предельно допустимую норму. Кроме того, во взорванной массе после взрыва остается значительное количество вредных газов (оксиды углерода и азота), которые при недостаточном воздухообмене могут загрязнять атмосферу карьера в течение длительного времени. (Конорев, Нестеренко 2000 г.)

Для массовых взрывов характерно вторичное газовыделение из взорванной горной массы, продолжающееся в отдельных случаях 10-15 ч. Максимальная концентрация окиси углерода во взорванной горной массе достигает 15-17\%, а превышающая предельно допустимую наблюдается до 100 и более часов. Газовыделение усиливается при выемочно-погрузочных операциях, при этом газы выделяются как из развала, так из породы, находяшейся в ковше экскаватора, кузова автосамосвала (Томаков 1994).

Загрязнение атмосферного воздуха при взрывных работах в угольных разрезах происходит за счет выделения вредных веществ с пылегазовым облаком и выделения оксида углерода из взорванной горной массы.

В условиях Южной Якутии при массовых взрывах (200-300 т ВВ) на угольном разрезе образуется пылегазовое облако объемом 15-20 млн м 3 с концентрацией пыли $0,135-0,217 \mathrm{kг} / \mathrm{M}^{3}$. пылегазовое облако поднимается на высоту до 1500-1700 м и в течение 4-6 часов рассеивает до 500 тонн пыли. Основная масса пыли (до 75\%) выносится за пределы разреза. Взрывные работы хотя и являются периодическими и кратковременными источниками пылеобразования, но при их применении выделяется количество пыли в единицу времени, превышающий в сотни раз ПДК. Общая запыленность распределяется следующим порядком: 40-50\% пыли образуется при взрывании горной массы, 20-25\% - при погрузке отбитой массы и 25-40\% - при транспортировке по внутрикарьерным дорогам. При этом в открытое пространство выносится взрывом 70-75\% пыли, погрузкой 15-20\% и транспортировкой 5-15\%. Радиус техногенного влияния разреза и сопутствующих производств достигает 50-70 км (Цыганков, 1994). 


\section{С.И. Миронова, В.В. Иванов}

Крепость коренных вскрышных пород разреза «Нерюнгринский» по шкале проф. М.М. Протодьяконова соответствует категории VIII-X, крепость угля - категории I-II. Коренная порода и частично уголь подлежат рыхлению взрывным способом.

Проектом принят вращательный способ бурения скважин с применением станков СБШ-320 B, СБШ-250-МНА, DM-H.

Количество обводненных скважин до 20\%. В качестве основных взрывчатых веществ для заряжения скважин применяются: гранулит УП-1 (66\% от общего объема расходуемых ВВ), гранулотол (15\%), сибирит (19\%).

Одновременно взрывается только один блок. За год производится 96 взрывов, 8 взрывов в месяц с интервалом в 3-4 дня.

- концентрации загрязняющих веществ в пылегазовом облаке достигают ПДКм.р. на расстоянии 4154,0 м от места взрыва в течение 13,8 минут при скорости ветра 5 м/с ( $\left.U^{*}\right)$;

- превышения санитарных норм в атмосферном воздухе на территории жилых массивов города при проведении взрывов не ожидается (расстояние около 8 км).

\section{Угольные склады}

Источниками выбросов пыли в атмосферу на угольных складах являются:

- разгрузка автосамосвалов с углем на территории складов;

- собственно территория складов, с которой в атмосферу сдувается угольная пыль;

- работающие на складах бульдозеры и экскаваторы. Пылевыделение происходит в процессе перемещения угля и его отгрузки.

Источники вспомогательных промплощадок разреза

Источниками загрязнения здесь является вспомогательные промплощадки разреза (АТБЦ, РМУ, закрытые стоянки легкового транспорта).

\subsection{3. Краткий анадиз данных по выбросам загрязняющих веществ}

Анализ валовых выбросов загрязняющих веществ показывает, что вклад источников вспомогательных площадок в загрязнение атмосферы составляет не более $0,6 \%$ от выбросов основных источников горнотранспортной части разреза.

Валовые выбросы загрязняющих веществ в атмосферу от источников разреза «Нерюнгринский» за 2002 г., принятые по отчетности форма 2-тп (воздух), приведены в табл. 1.7. 
Таблица 1.7

Валовые выбросы загрязняющих веществ в атмосферу от источников разреза «Нерюнгринский» за 2002 г.

\begin{tabular}{|c|c|c|c|}
\hline $\begin{array}{l}\text { № } \\
\Pi / \Pi\end{array}$ & $\begin{array}{c}\text { Код } \\
\text { вещества }\end{array}$ & Наименование вещества & $\begin{array}{c}\text { Валовый выброс, } \\
\text { т/год }\end{array}$ \\
\hline 1 & 301 & Азота оксиды & 85,222 \\
\hline 2 & 330 & Серы диоксид & 0,115 \\
\hline 3 & 337 & Углерода оксид & 78,046 \\
\hline 4 & 322 & Серная кислота & 0,0018 \\
\hline 5 & 123 & Железа оксид & 0,146 \\
\hline 6 & 143 & Марганец и его соединения & 0,034799 \\
\hline 7 & 156 & Натриевая селитра & 0,001336 \\
\hline 8 & 184 & Свинец и его соединения & 0,00001 \\
\hline 9 & 203 & Хром шестивалентный & 0,001316 \\
\hline 10 & 305 & Аммиачная селитра & 0,070529 \\
\hline 11 & 328 & Сажа & 0,0256 \\
\hline 12 & 342 & Фториды газообразные & 0,024596 \\
\hline 13 & 344 & Фториды плохорастворимые & 0,014 \\
\hline 14 & 401 & Углеводороды & 0,032 \\
\hline 15 & 602 & Бензол & 0,004 \\
\hline 16 & 616 & Ксилол & 0,004 \\
\hline 17 & 621 & Толуол & 0,007 \\
\hline 18 & 2704 & Бензин нефтяной & 0,058 \\
\hline 19 & 2902 & Взвешенные вещества & 1949,337 \\
\hline 20 & 2909 & Пыль неорганическая до $20 \% \mathrm{SiO}_{2}$ & 0,03276 \\
\hline 21 & 2930 & Пыль абразивная & 0,26848 \\
\hline \multirow[t]{5}{*}{22} & 2936 & Пыль древесная & 1,861422 \\
\hline & & Всего: & 2115,308 \\
\hline & & В том числе: & \\
\hline & & - твердые & 1951,793 \\
\hline & & - газообразные и жидкие & 163,515 \\
\hline
\end{tabular}




\begin{tabular}{|c|c|c|c|c|c|c|c|c|c|c|c|c|c|c|c|}
\hline & & $\vec{a}$ & $\mathrm{O}^{N}$ & 2 & $\begin{array}{l}\text { के } \\
\text { สิ }\end{array}$ & 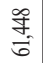 & $\begin{array}{l}\infty \\
\infty \\
\vdots \\
\sim \\
\sim\end{array}$ & $\stackrel{\wp}{\infty}$ & 1 & 1 & 1 & 1 & 1 & 1 & क् \\
\hline & & 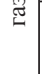 & ○ & $\infty$ & $\begin{array}{l}\stackrel{:}{0} \\
\stackrel{\infty}{=}\end{array}$ & 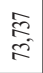 & $\stackrel{\circ}{\circ}$ & $\frac{\pi}{6}$ & 1 & 1 & 1 & 1 & 1 & 1 & $\begin{array}{l}3 \\
0 \\
0 \\
0 \\
=\end{array}$ \\
\hline & 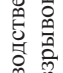 & & 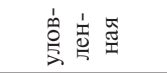 & $=$ & 里 & $\begin{array}{l}\text { \% } \\
\check{2} \\
\end{array}$ & $\begin{array}{l}E \\
\stackrel{E}{E} \\
\text { d् }\end{array}$ & $\begin{array}{l}\text { fै } \\
\text { चे }\end{array}$ & 1 & 1 & I & 1 & 1 & 1 & $\begin{array}{l}\infty \\
0 \\
0 \\
0 \\
0\end{array}$ \\
\hline & 苍 & 官 & 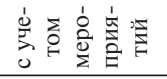 & 0 & हृ & $\underset{7}{\stackrel{7}{7}}$ & $\stackrel{2}{\frac{\pi}{2}}$ & $\begin{array}{l}\overline{0} \\
i \\
i\end{array}$ & I & 1 & 1 & 1 & 1 & 1 & $\underset{8}{\overrightarrow{2}}$ \\
\hline 总 & & & 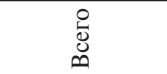 & $\cong$ &  & 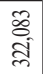 & \begin{tabular}{l}
3 \\
$\vdots$ \\
\hdashline \\
\hdashline
\end{tabular} & 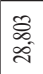 & 1 & 1 & 1 & 1 & 1 & 1 & 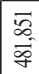 \\
\hline 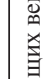 & 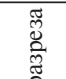 & & 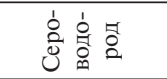 & \pm & 1 & 1 & 1 & 1 & 1 & 1 & 1 & 1 & 1 & $\bar{\sigma}$ & $\overline{8}$ \\
\hline 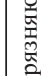 & 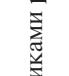 & & 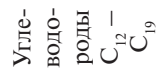 & $m$ & 1 & 1 & 1 & 1 & 1 & I & 1 & 1 & 1 & हू. & $\bar{\sigma}$ \\
\hline $\begin{array}{l}\text { E్ } \\
\text { 苂 }\end{array}$ & 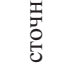 & & $U$ & $\simeq$ & 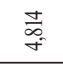 & $\stackrel{m}{\approx}$ & $\stackrel{2}{3}$ & : & g్ & $\begin{array}{l}\text { 营 } \\
\text { 号 }\end{array}$ & : & है: & । & 1 & $\underset{E}{E}$ \\
\hline 望 & 吾 & 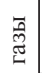 & J & $=$ & $\begin{array}{l}\infty \\
\substack{6 \\
m \\
m}\end{array}$ & 음 & $\stackrel{\text { 学 }}{=}$ & ఏ & ฉิ & 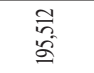 & $\stackrel{\infty}{=}$ & $\stackrel{\infty}{=}$ & I & 1 & 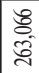 \\
\hline 青 & 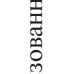 & & Z & 으 & $\overrightarrow{\widetilde{\sigma}}$ & స్ & $\underset{\Xi}{\stackrel{ \pm}{二}}$ & 旾 & ॠू & $\begin{array}{l}\text { क्ते } \\
\text { శี }\end{array}$ & ह్ & ह్ & 1 & । & तิ \\
\hline $\begin{array}{l}0 \\
0 \\
0 \\
0.00 \\
0 \\
0\end{array}$ & 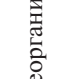 & & $\stackrel{O}{ }^{\sim}$ & $a$ & 蒙 & 站 & 祫 & 8 & $\begin{array}{l}\text { 范 } \\
\text { ते }\end{array}$ & 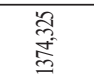 & స్లె & लु & 1 & 1 & 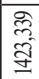 \\
\hline 응 & 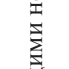 & & O & $\infty$ & $\begin{array}{l}\stackrel{\circ}{\circ} \\
\stackrel{d}{\infty}\end{array}$ & 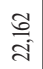 & $\stackrel{\text { 总 }}{=}$ & 吾 & 总 & $\begin{array}{l}\bar{\sigma} \\
\overline{\text { हे }}\end{array}$ & जี & है & 1 & 1 & $\frac{2}{\stackrel{2}{\sigma}}$ \\
\hline & 浐 & & 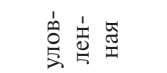 & $n$ & ț & $\begin{array}{l}\text { 品 } \\
\text { ల్ల }\end{array}$ & 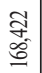 & $\begin{array}{l}\tilde{2} \\
\stackrel{2}{+}\end{array}$ & 1 & $\begin{array}{l}\text { 'aे } \\
\text { ồ }\end{array}$ & 1 & 1 & 1 & 1 & 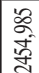 \\
\hline & 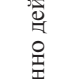 & 惫 & 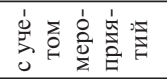 & 0 & 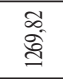 & 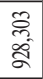 & 空 & 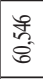 & 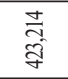 & $\begin{array}{l}\overrightarrow{\text { g }} \\
\underset{\sim}{\sim}\end{array}$ & $\begin{array}{l}\infty \\
\infty \\
\infty \\
\infty\end{array}$ & 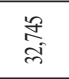 & $\stackrel{\circ}{\circledR}$ & । & 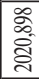 \\
\hline & 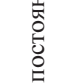 & & 高 & in & 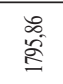 & 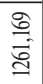 & $\begin{array}{l}\mathscr{\sigma} \\
\text { హे }\end{array}$ &  & $\begin{array}{l}\stackrel{\Xi}{\approx} \\
\underset{\gamma}{\gamma}\end{array}$ & $\begin{array}{l}\stackrel{2}{2} \\
\tilde{\sigma} \\
\tilde{\sigma}\end{array}$ & $\underset{\infty}{\infty}$ & 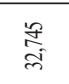 & $\stackrel{-}{\infty}$ & 1 & 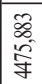 \\
\hline & W $\cdot 0$ IGL & йоा & 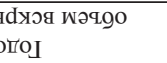 & 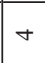 & 赵 & ళ్లి & 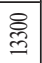 & § & 疍 & 高 & 1 & 1 & 1 & & \\
\hline & 'OIqL ' & LoOH & пок ьеяогој & $m$ & \& & $\stackrel{ }{\circ}$ & $\stackrel{ }{\circ}$ & 蒠 & 1 & 害 & §్ & 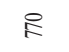 & 8 & & \\
\hline & & 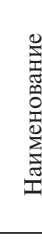 & 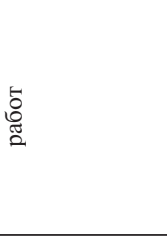 & $\mathrm{n}$ & 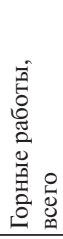 & 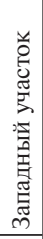 & 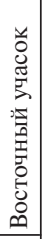 & 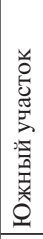 & 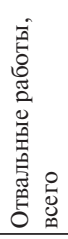 & 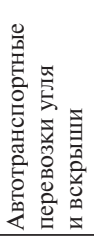 & 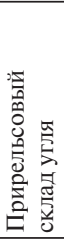 & 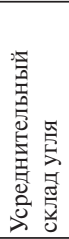 & 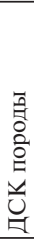 & 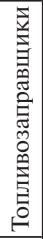 & 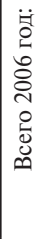 \\
\hline & & & & - & - & $=$ & $\stackrel{?}{=}$ & $\stackrel{m}{9}$ & $N$ & $m$ & t & in & 6 & $r$ & \\
\hline
\end{tabular}




\section{Глава 1. Недропользование в Южной Якутии}

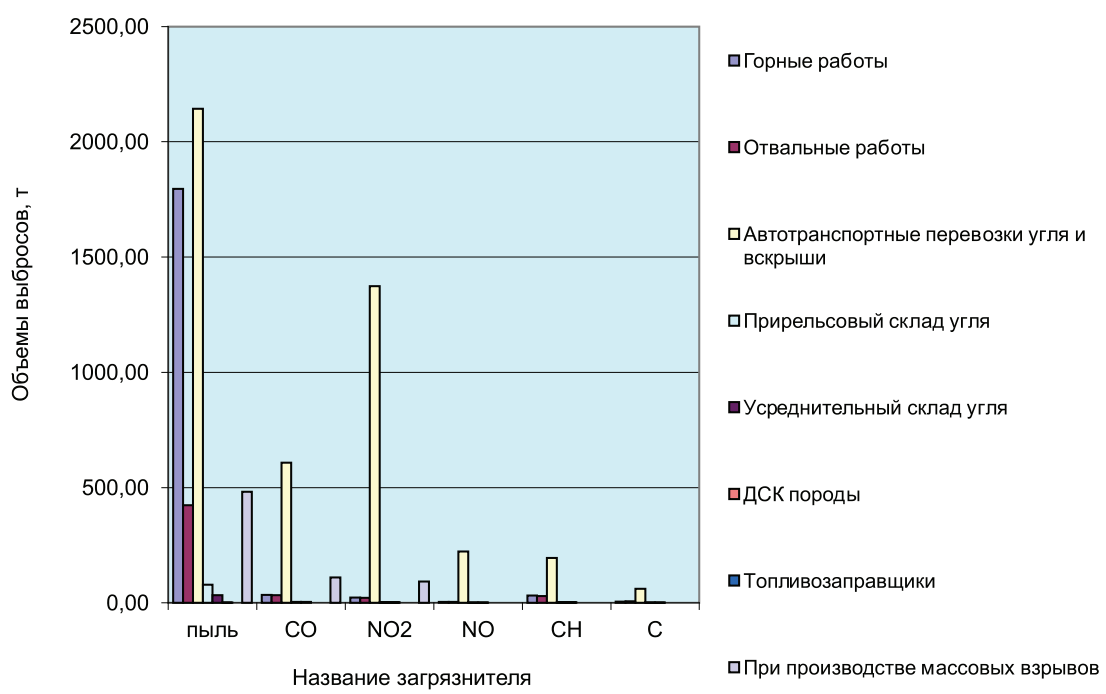

Рис. 1.2. Выбросы загрязнителей в атмосферный воздух по источникам выбросов

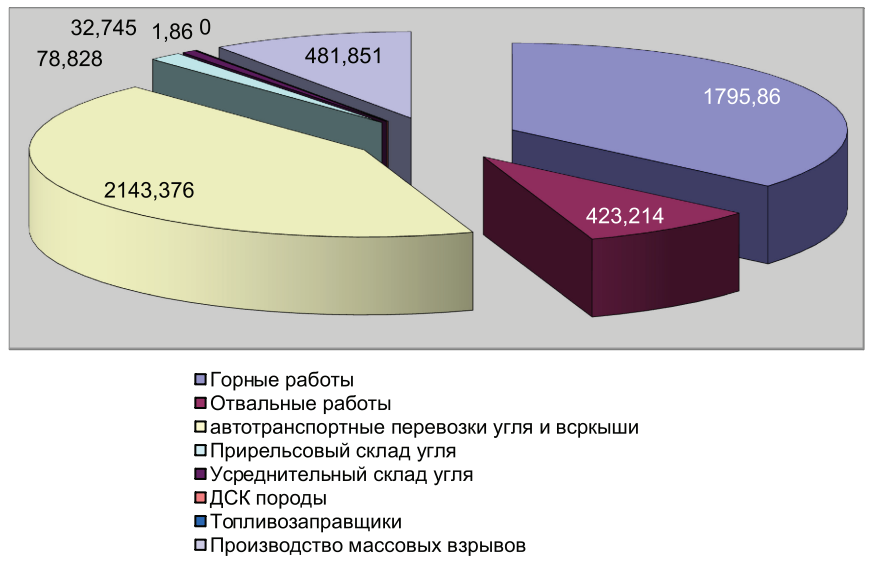

Рис. 1.3. Выбросы пыли

В выбросах значительную часть составляют взвешенные вещества, микроэлементный состав которых неизвестен. В то же время известно, что многие микроэлементы, в том числе и обладающие токсичными, 
канцерогенными, мутагенными свойствами тяжелые металлы (ТМ) способны к накоплению в элементах среды и внедрению в круговорот веществ (Чебаненко, Майсюк, 1999). К ТМ имеющим наивысший класс опасности относятся бериллий, хром, ртуть, никель, свинец, цинк, медь, ванадий и др. Микроколичественное содержание их в взвешенном веществе компенсируется макроколичеством выбросов.



Рис. 1.4. Выбросы оксида углерода

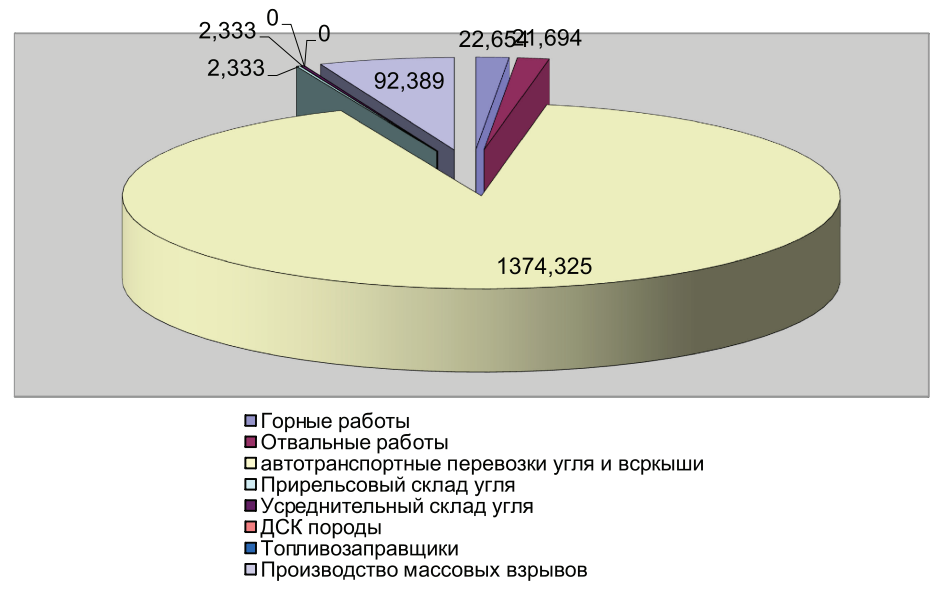

Рис. 1.5. Выбросы оксида азота 


\section{Гдава 2. ПРИРОДНО-КДИМАТИЧЕСКИЕ ОСОБЕННОСТИ РЕГИОНА}

Нерюнгринское каменноугольное месторождение расположено на юго-востоке Алдано-Чульманского угленосного района Южно-Якутского бассейна на расстоянии 400 км от ж/д станции Б. Невер. Из всех имеющихся на месторождении пластов для открытой разработки назначен пласт «Мощный», по форме представляющий собой мульдообразную складку протяженностью 6 км и шириной 3,9 км (Совершенствование технологии..., 2004).

Геология и рельеф. Чульманская впадина, расположенная в междуречье Олекмы и Тимптона, является самой крупной из серии мезозойских впадин сочленения Алданского щита со Становой складчатой областью. Южная граница впадины - тектоническая, северная, восточная и западная - эрозионные, хотя и определяются в значительной степени разрывными деформациями (Геология СССР. Южная Якутия, 1972). В геологическом строении территории принимают участие карбонатные породы венд-нижнекембрийского и терригенные отложения мезозойского возрастов. Повсеместное распространение имеют четвертичные отложения различного генезиса, преимущественно имеющие грубообломочный состав.

В рельефе территория представляет собой приподнятое плоскогорье с множеством возвышающихся хребтов и гольцовых групп. Высшие отметки окружающих впадину хребтов 1500-1800 м над уровнем моря. Наиболее низкий уровень с абсолютными высотами 700-800 м составляет днища котловин. Хребты сложены мощными толщами гнейсов и кристаллических сланцев архейского возраста, которые прорваны интрузиями и полями гранитов. На более пологом склоне к Алданскому нагорью находится небольшая толща доломитов и известняков, выходы которых отмечаются у поселков Б. Хатыми и Юхта (Коноровский, 1984).

Чульманская впадина сложена с поверхности юрскими песчаниками и алевролитами с прослоями углей. На всей остальной части района преобладают кристаллические сланцы и гнейсы, прерываемые местами гранитами. Сильнощебнистый элювий этих пород и является почвообразующей породой для лесных почв района. Мелкозем элювия юрских пород супесчаный, а архейских кристаллических - легко- и среднесуглинистый. Она имеет типично расчлененный рельеф с местным базисом эрозии в пределах 100-200 м. Преобладают выпукло-склоновые 
местоположения с крутизной в 4-10․ Лишь междуречные водораздельные пространства вдали от рек имеют более выровненную поверхность. Чульманская впадина, к которой относится район исследований, распадается на ряд более мелких котловин, разделенных между собой невысокими поднятиями. Наиболее четко впадину делит на две половины хр. Стланиковый. Первая половина (собственно Чульманская впадина) более приподнята и охватывает бассейны рек Чульман и Горбыллах, вторая - Унгро-Якокитская впадина.

Пониженные участки территории представлены долинами крупных и мелких рек. Последние заняты марями и обычно имеют одну террасу с небольшой толщей галечниково-щебнистых делювиально-аллювиальных отложений. Механический состав мелкозема зависит от состава пород прилегающих к речке водораздельных поверхностей.

Климат Чульманской впадины континентальный, характеризуется низкими годовыми и зимними температурами и высокой относительной влажностью (табл. 2.1). Заморозки возможны во все летние месяцы. Продолжительность безморозного периода 48 дней. За счет относительной приподнятости района она почти в 2 раза меньше, чем в лежащих севернее на $7^{\circ}$ широты окрестностях г. Якутска. Сумма температур выше $10^{\circ}$ равна $1158^{\circ}$, что на $400^{\circ}$ меньше.

Таблица 2.1 Многолетние показатели климатических условий Чульманской впадины (по данным метеостанции аэропорта п. Чульман)

\begin{tabular}{|c|c|c|c|c|c|c|c|}
\hline \multirow{2}{*}{ Показатель } & \multicolumn{5}{|c|}{ Месяц } & \multirow{2}{*}{ Год } & Период \\
\hline & V & VI & VII & VIII & IX & & VI-VIII \\
\hline $\begin{array}{l}\text { Температура воздуха, }{ }^{\circ} \mathrm{C} \\
\text { Вероятность заморозков, \% } \\
\text { с температурой ниже } \\
0^{\circ} \\
-3^{\circ}\end{array}$ & $\begin{array}{r}3,6 \\
- \\
-\end{array}$ & $\begin{array}{r}12,2 \\
85 \\
26\end{array}$ & $\begin{array}{c}15,9 \\
14 \\
3\end{array}$ & $\begin{array}{r}12,4 \\
52 \\
11\end{array}$ & - & $\begin{array}{r}9,4 \\
- \\
-\end{array}$ & $\begin{array}{r}13,5 \\
- \\
-\end{array}$ \\
\hline $\begin{array}{l}\text { Относительная влажность, } \% \\
\text { Осадки, мм при обеспеченности } \\
50 \% \text {-ной } \\
10 \% \text {-ной } \\
90 \% \text {-ной } \\
\text { Испаряемость расчетная, мм } \\
\text { Обеспеченность осадками } 0,8 \\
\text { испаряемости, \% }\end{array}$ & $\begin{array}{l}51 \\
92 \\
18 \\
-\end{array}$ & $\begin{array}{c}75 \\
112 \\
44 \\
75 \\
\\
60\end{array}$ & $\begin{array}{c}101 \\
176 \\
34 \\
80 \\
\\
69\end{array}$ & $\begin{array}{c}106 \\
203 \\
46 \\
55 \\
\\
87\end{array}$ & $\begin{array}{c}55 \\
94 \\
22 \\
-\end{array}$ & $\begin{array}{c}496 \\
- \\
- \\
-\end{array}$ & $\begin{array}{c}282 \\
582 \\
352 \\
-\end{array}$ \\
\hline
\end{tabular}


В районе выпадает много осадков (500-600 мм за год), большая часть их приходится на летние месяцы. Эвапотранспирационный расход составляет 220-250 мм. В результате более половины выпадающих атмосферных осадков в виде поверхностного и внутрипочвенного стоков уходит по разветвленной гидрографической сети за пределы района. Это обусловливает интенсивное промывание почв повышений и развитие заболачивания на слабо покатых склонах и в долинах рек. В отдельные годы в Чульмане и Нагорном не бывает вегетационного периода и в среднем 3 раза в лето выпадают осадки в виде града (Климатический справочник).

Гидрология. Гидрографическая сеть района густая вследствие большого количества осадков и расчлененности рельефа. Крупные реки это притоки Алдана - Тимптон и Учур-Гонам являются реками горного типа. Основное их питание происходит за счет талых и дождевых вод. Многие мелкие речки и ручьи не имеют стока, а такие относительно крупные реки как Чульман, Тимптон, Унгра в зимнее время имеют небольшой сток. В наиболее суровые зимы даже эти реки на многих участках промерзают до дна. Наибольший подъем уровней воды в реках отмечается не весной, а после сильных летних дождей. Высокий подъем воды после дождей в июле-августе исключает возможность осушения заболоченных участков на 1-й надпойменной террасе крупных рек.

Для района характерны также трещинно-пластовые подземные воды артезианских бассейнов (Пиннекер, Писарский, 1977).

Многолетняя мерзлота. В пределах рассматриваемой территории, в Чульманской впадине (плоскогорье), многолетняя мерзлота имеет островное распространение и занимает 50-60\% территории, а мощность ее лишь на отдельных участках долин превышает 100 м (Фотиев, 1965). Многолетнемерзлые породы отсутствуют на некоторых плоских водораздельных пространствах.

В разрезе криолитозоны Чульманской впадины преобладают скальные и полускальные эпигенетически промерзавшие породы с унаследованными трещинными текстурами. Мощность рыхлых отложений, находящихся в многомерзлотном состоянии, как правило, не превышает 5-7 м. Они представлены делювиальными, коллювиальными отложениями в нижних частях склонов и аллювием - в долинах. Объемная льдистость отложений достигает 40-60\% (Южная Якутия, 1975).

Распространение многолетнемерзлых пород обусловлено общими суровыми микроклиматическими условиями, отсутствием инфильтрации, малоснежностью, сильной затененностью склонов друг другом, характером растительности и температурной инверсией. Глубина зимнего промерзания, как и оттаивания, различна и зависит от состава 
растительности, литологического состава грунтов, их влажности, рельефа, абсолютной высоты местности. В связи с этим величина протаивания грунтов колеблется от $0,3-0,5$ м на заболоченных участках с мощным слоем мохового покрова.

К криогенным явлениям относятся широко распространенная в исследуемом районе трещиноватость поверхности грунта, а также пучение грунтов, торфяные бугры. Часто встречаются наледи в долинах рек и ручьев.

Почвенный покров. Распространение почв по району обусловлено горными условиями территории, расчлененностью территории, материнскими почвообразующими породами, несколько меньшей континентальностью климата, большой влажностью и не сплошным распространением многолетнемерзлых пород. Горные условия территории способствовали образованию горных, маломощных, грубых по механическому составу почв, с укороченным почвенным профилем (25-70 см), с большой щебнистостью и каменистостью всех генетических горизонтов, так как формирование их протекало в условиях расчлененного горного рельефа на грубообломочных продуктах выветривания твердых пород. Одна из особенностей почвенного покрова Чульманской впадины - отсутствие засоленных почв. Одни исследователи это объясняют наличием пород лишенных солепроявлений (Иванов, Левицкий, 1960), другие - высоким увлажнением (Коноровский, 1984).

Наиболее распространенными типами почв в исследуемом районе являются мерзлотные подзолистые, мерзлотные болотные и мерзлотные таежные. Отдельно отмечены мерзлотные пойменные и мерзлотные слаборазвитые (примитивные) (Еловская, 1977).

Горные условия территории способствовали образованию горных, маломощных, грубых по механическому составу почв, с укороченным почвенным профилем (25-70 cм), с большой щебнистостью и каменистостью всех генетических горизонтов, так как формирование их протекало в условиях расчлененного горного рельефа на грубообломочных продуктах выветривания твердых пород.

Одна из особенностей почвенного покрова Чульманской впадины отсутствие засоленных почв. Одни исследователи это объясняют наличием пород лишенных солепроявлений (Иванов, Левицкий, 1960), другие - высоким увлажнением (Коноровский, 1984).

Наиболее распространенными типами почв в исследуемом районе являются мерзлотные подзолистые, мерзлотные болотные и мерзлотные таежные. Отдельно отмечены мерзлотные пойменные и мерзлотные слаборазвитые (примитивные). 
Открытая разработка угольных месторождений оказывает негативное воздействие на почвенный покров. В процессе разработки месторождений для размещения отходов горного производства (вскрышных пород, шламов и др.) из биологического цикла изымаются продуктивные земли.

Разработка угольных разрезов сопровождается значительными объемами пылевых выбросов. Наиболее серьезное последствие интенсивного выноса угольной пыли - загрязнение почв, прилегающих к району разработок, тяжелыми металлами. Кроме того, газопылевые выбросы оказывают влияние и на свойства почв, снижая почвенное плодородие. В районе разработок угольных разрезов ухудшение почвенного плодородия и экологического состояния почв создают неудовлетворительные санитарно-гигиенические условия для жизни человека и неблагоприятные условия для окружающей среды. Кроме того, отработка угольных месторождений связана с извлечением на поверхность больших масс пустых пород. Так, например, карьерная добыча каждой тысячи тонн угля требует размещения 3,6 тыс. м³ вскрышных пород (Красавин, 1983). Значительный ущерб природной среде причиняют вскрышные породы, сосредоточенные в отвалах. Продукты выветривания угля и пустых пород содержат различные химические элементы. Среди выщелачиваемых содержатся и токсичные. В процессе рассеяния и миграции тяжелых металлов и других экологически опасных элементов из угольной пыли негативно изменяется геохимический состав почв, что соответственно отражается на экологическом состоянии окружающей среды.

Тяжелые металлы также входят в состав отходов промышленного производства. Из-за высокой сорбционной способности почвенные системы наиболее достоверно регистрируют ранние негативные последствия техногенеза. Например, Нерюнгринская ГРЭС, работающая на каменном угле Нерюнгринского разреза обладает мощностью 570 мВт и вырабатывает 2240 млн кВт/ч. Она снабжена фильтром типа ЭГА-2-88-12-6-4у, улавливающим $98 \%$ золы дымовых газов. Тем не менее, расчеты, проведенные М.В. Щелчковой (1998) показывают, что ежегодный выброс золы в атмосферу составляет 4058 т. В ней обнаружено содержание хрома -33 , никеля - 33, ванадия -67 , кобальта - 10, цир-

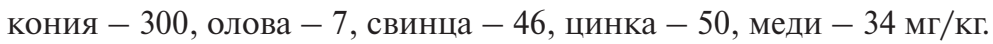

Изучение геохимии снежного покрова В.Н. Макаровым и др. (1990) свидетельствует, что разработка угольного месторождения изменяет его химический состав. В снежном покрове угольного разреза устанавливаются ореолы аномальных концентраций веществ, которые входят в состав каменного угля и вскрышных пород или составляют продукты их 
трансформации. Аномальные поля прослеживаются на 15-20 км к югу от угольного разреза.

Расчлененность рельефа усиливает неравномерность распределения техногенных выбросов на поверхность почвы и предопределяет вариабельность в них микроэлементов. Продукты выветривания угля и пустых пород переносятся атмосферным воздухом и природными водами. Последнее обусловлено тем, что выпадающие атмосферные осадки смывают с угольного отвала и с поверхности почв угольную пыль и вещества, которые по естественным водотокам распространяются на большие расстояния. В результате техногенные потоки веществ способствуют негативному изменению природного геохимического состава почв и влияют на экологическое состояние окружающей среды на значительной территории исследуемого района.

Исследованиями установлено, что Нерюнгринский угольный разрез и Нерюнгринская ГРЭС являются основными источниками поступления в почву и окружающую среду микроэлементов, в том числе и токсичных.

Микроэлементный анализ золы лесной подстилки фиксирует накопление титана, хрома, молибдена, меди, марганца, мышьяка, свинца и цинка. Из них титан и свинец проявляют халькофильные свойства, хром и молибден являются ярко выраженными литофилами.

Анализ распределения микроэлементов в гумусовом горизонте фиксирует незначительные концентрации ванадия и никеля. Содержание остальных микроэлементов по почвенному профилю слабо дифференцировано с незначительным увеличением вниз по профилю, что связано с влиянием подстилающих пород. В целом, на исследуемой территории значительные концентрации микроэлементов отмечаются - в моховом покрове, лесной подстилке и гумусовом горизонте. Как известно, тяжелые металлы, достигая определенных концентраций, губительно действуют на живые организмы, растения. В дальнейшем, вовлекаемые в биологический круговорот, тяжелые металлы с длительным периодом детоксикации в природных системах будут накапливаться в них и представят опасность для окружающей среды.

По данным геохимического анализа почв на основе карты загрязнения снежного покрова нами установлена градация последствий техногенного воздействия предприятий разреза «Нерюнгринский» на почвы (Иванов и др., 2012):

1 - зона сильного воздействия - в 2-7 км к юго-востоку от Нерюнгринского разреза. Мерзлотные подзолистые, мерзлотные таежные и торфяно-болотные почвы данного участка, попадают в зону влияния 
промышленных выбросов Нерюнгринского угольного разреза. В подстилке почв содержание титана, марганца, меди, цинка в 2-3 раза выше ПДК, концентрации свинца превышают ПДК в 5 раз (табл. 4.3.1; 4.3.2, рис. 4.3.1-4.3.5). В гумусовом горизонте количество марганца, титана выше ПДК в 2 раза. В данном районе отмечаются 3 элемента I класса опасности (мышьяк, свинец, цинк), один элемент II класса опасности (медь) и III класса - цирконий, превышающие ПДК.

$2-$ зона среднего воздействия - к юго-востоку в 7-34 км и в 16-19 км к северу от объекта. Участок находится вдоль преобладающего направления действия ветров от техногенных объектов. Это согласуется с исследованиями В.Н. Макарова и др. (1990), которые установили, что на расстоянии 15-20 км. Кроме того, в пос. Беркакит производится механизированная очистка вагонов. На складе скоплено 120 тыс. т угля после зачистки вагонов, которая также загрязняет окружающую среду. Так же возможно, что аномальная концентрация элементов обусловлена более низким местоположением зоны, чем ГРЭС и разрез. Здесь происходит смыв элементов загрязнителей поверхностными стоками со склонов и накопление их в зоне.

3 - зона слабого воздействия - к юго-востоку от Нерюнгринского угольного разреза в 34-58 и в 16-56 км к северо-западу и к северу от объекта.

На участке накопление тяжелых металлов отмечается в бассейне рек Иенгра и Тимптон. В таежной почве фиксируются марганец, цинк, свинец, в торфянисто-гумусовом горизонте - титан, превышающие ПДК в 2 раза. В устье р. Сыганах в подстилке мерзлотной таежной почвы содержание титана выше ПДК, в торфянисто-гумусовом горизонте количество цинка, свинца выше ПДК в 2 раза. Возможно, загрязнение данного района связано с добычей золота, которая проводится на данной территории. Как известно, при открытых разработках полезных ископаемых горные породы, извлекаемые на дневную поверхность, содержат различные химические элементы. Среди выщелачиваемых оказываются и токсичные. Вокруг разработанного месторождения в таких случаях образуется ореол рассеяния химических элементов, которые попадают в почву и живые организмы. Продукты выветривания пород переносятся атмосферным воздухом и природными водами. Техногенные потоки вещества в районах разработок полезных ископаемых могут быть причиной изменения геохимических свойств почв.

Растительному покрову территории и воздействию промышленных предприятий на растительность посвящается следующая глава. 


\section{Гдава 3. РАСТИТЕДЬНЫЙ ПОКРОВ РЕГИОНА}

В результате добычи полезных ископаемых происходят значительные изменения в структуре литогенной основы, и природный ландшафт модифицируется в природно-техногенный или чисто техногенный.

В процессе разрушения фундамента ландшафта на поверхности появляются новые для данной местности глубинные породы с незначительной степенью выветренности и низкой биогенностью, возникают различные формы техногенного неорельефа, происходит гибель всех компонентов биоты, т.е. возникает такое явление, которое в биогеоценологии известно как катастрофическая сукцессия биогеоценоза (Трофимов и др., 1979).

В Кемеровской области сосредоточены огромные запасы каменного угля, которые оцениваются в 524,4 млрд т. Общая площадь Кузнецкого бассейна насчитывает 27 тыс. км² (Потапов, Мазикин и др., 2005). В настоящее время добычу угля в регионе ведут более 60 шахт и 50 угольных разрезов (Артемьев, 2004). Здесь ежегодно добывается $76 \%$ коксующихся марок углей и свыше половины общего объема добываемого угля в России. Доля Кузбасса в общероссийском экспорте составляет около $80 \%$.

Добыча угля сопровождается огромным экологическим ущербом природным экосистемам. Неизбежным следствием горно-промышленного производства являются карьерные выемки, отходы в виде отвалов вскрышных горных пород, подработанные шахтовые земли. Ежегодно в Кузбассе на поверхность извлекается около 450 млн т вскрышных и вмещающих пород, более 14 млн т отходов углеобогащения, 3 млн т золошлаковых отходов (Счастливцев, 2003, 2005; Потапов, Мазикин и др., 2005). Специалистами ИУУ СО РАН установлено, что на 1 млн т добытого угля приходится 36 га уничтоженного слоя плодородной земли (Счастливцев, 2003). По состоянию на начало 2008 года на территории Кемеровской области по «Материалам к Государственному докладу ...» (2008) официально числится 62361 га нарушенных земель. Однако по оценкам специалистов площадь бедлендов в бассейне составляет не менее 91,7 тыс. га, включая и зоны подтопления в районах закрытых угольных шахт (Счастливцев, 2003).

В 2008 году в Кузбассе добыто почти 180 млн т угля. К 2025 году общий объем добычи угля планируется увеличить до 270 млн тонн в год. Прогнозная площадь отвалов увеличится на $20 \%$ и достигнет к тому времени 120-150 тыс. га (Счастливцев, 2005). Исследования, проведенные 
в Кузбассе, с целью определения экологической емкости территории показали, что уровень техногенного загрязнения области превышен в 4 раза. Дальнейшее увеличение темпов добычи угля неизбежно приведет к усугублению и без того крайне сложной экологической обстановки в Кузнецкой котловине, где сосредоточено $70 \%$ населения (Литвененко и др., 2008).

Кузнецкий угольный бассейн расположен на уникальной в геологическом, ландшафтном, почвенном, биологическом отношении территории. Почвенный покров Кузбасса, по мнению И.М. Гаджиева с сотр. (2001), представлен 11 типами, 33 подтипами, 100 родами, и более 1500 видами почв. Биологическое разнообразие представлено более 1500 видов растений, 429 видов позвоночных животных (Биоразнообразие..., 2003). Оно обеспечивает сохранение природных экосистем, необходимых для стабильности окружающей среды и является залогом поддержания необходимых экологических условий для жизни человека. Большая часть Кемеровской области вошла в Алтае-Саянский экорегион - один из двухсот мировых территорий, характеризующихся повышенным биологическим разнообразием (Система особо охраняемых..., 2001).

Основной экологической проблемой при увеличении добычи угля является ухудшение среды обитания человека. В результате горнодобывающей деятельности происходят следующие негативные явления: изменение ландшафтов; нарушение почвенного покрова и развитие процессов эрозии; загрязнение воздушного бассейна; загрязнение воды; обеднение биологического разнообразия. Загрязнение окружающей среды и изменение экологических параметров имеет медленный, аккумулятивный эффект накопления неблагоприятных последствий для здоровья человека, проявляющийся через много десятилетий. Интегральным показателем состояния населения, проживающего в угледобывающих районах, является увеличение естественной убыли населения, высокий уровень врожденных аномалий, повышенный фон онкологических, нервных, сердечных заболеваний, системы крови, дыхательных путей, высокий удельный вес групп населения, уязвимых к воздействию окружающей среды.

Исследования особенностей формирования растительного покрова карьерно-отвальных ландшафтов в нашей стране были начаты в 60-х годах XX века. Было обнаружено, что процессы зарастания в новых техногенных условиях имеют характерные особенности и общие закономерности. Это позволило В.В. Тарчевскому (1967) выделить из общей ботаники новое научное направление - промышленную ботанику. Он писал: «Установлено, что растения в зоне промышленных предприятий имеют значительные отклонения в характере морфогенеза, фотосинтеза, 
биохимического состава, сингенетических смен. Это с полным основанием позволяет ставить вопрос о выделении специального научно-производственного отдела ботаники - промышленная ботаника».

Первые работы в этом направлении проводились на Урале (Тарчевский, 1959, 1964, 1967, 1970 а, б; Лукьянец, 1972, 1974; Шилова, 1974, 1977; Махонина, Чибрик, 1974, 1975; Колесников и др., 1976; Терехова, 1984; Чибрик, Плошко, 1989; Меньшиков, 1990; Чибрик, 1979, 1992; Чибрик, Шмелева, 1992). Исследования территорий, нарушенных горными работами, проводились также в Подмосковном угольном бассейне (Моторина, Ижевская, 1967, 1973, 1980; Моторина, 1970, 1975, Моторина, Ижевская, Савич, 1976; Моторина, Зайцев, 1980); в условиях Крайнего Севера (Дружинина, 1985; Творогов, 1988; Капелькина, 1993; Ребристая, Хитун, Чернядьева, 1993; Хитун, Ребристая, 1994; Антропогенная динамика растительного покрова Арктики и Субарктики: принципы и методы изучения, 1995; Копцева, 2005; Копцева, Сумина, Тягнерева, 2007; Сумина, 1991, 1996; 2010) и Чукотского полуострова (Пугачев, Тихменев, 2005, 2008; Пещеров, 2009; Сумина, Яцкевич, 1990), Приморья (Леонтьев, 1966; Саламатова, Плошко, 1992; Родаева, 2004), на территории КАТЭКа (Титлянова и др, 1993, Миронычева-Токарева, 1998); а также на сопредельных с Россией территориях - в Донбассе (Рева, Бакланов, 1974; Рева, Хархота, Дмитриенко, 1978), в угольных районах Республики Казахстан (Куприянов, 1989, 1992; Куприянов, Акулов, 1990; Куприянов, Манаков, 1995; Куприянов, Манаков, 2008), в Якутии (Лебедева, Лонкунова, 1990; Миронова, 1996, 2000; Петрова, 1994).

Кузбасс был одним из первых регионов, где стали отрабатываться методы и приемы биологической рекультивации. Этому способствовало создание стационара ИПА СО РАН в с. Атаманово и работы новосибирских почвоведов С.С. Трофимова (Трофимов и др., 1979), И.М. Гаджиева (Гаджиев и др., 2001), В.М. Курачева и В.А. Андроханова (Экология и рекультивация..., 1992; Андроханов и др., 2000, 2004).

Начальные флористические исследования естественного зарастания отвалов Кузбасса проводились В.В. Тарчевским и Т.С. Чибрик (1970), Е.Р. Кандрашиным (1979 а, б; 1988,) а в дальнейшем продолжены А.Н. Куприяновым и Ю.А. Манаковым (Куприянов и др., 1996, 2006; Манаков, 1997, 2000, 2004, 2009). В последнее время стали проводиться синтаксономические исследования нарушенных земель Кузбасса (Ветлужских, 2003, 2008).

Изучение процессов и закономерностей развития растительного покрова на нарушенных территориях является фундаментальной задачей для решения вопросов ускоренного, направленного процесса восстановления 
хозяйственной и экологической ценности нарушенных земель. Этой проблеме посвящена данная работа, которая является итогом многолетнего (1995-2009 гг.) изучения флоры техногенных ландшафтов и ее распределение в зависимости от экологических условий местообитаний.

\section{1. Естественная растительность}

Растительность исследуемой территории входит в Алданский и Учурский горным среднетаежным округам Южноякутской провинции сосново-лиственничной с участием темнохвойных пород тайги (Леса среднетаежной ..., 1994). Первые данные о растительности Алданского района имеются в работах А.В. Куминовой (1936), Л.И. Тюлиной (1957). Сведения о типах лесов в долине Алдана даны В.С. Коржевиным (1934). Леса и лесные ресурсы Верхнего Алдана описаны Л.К. Поздняковым и В.И. Гортинским (1960), Л.К. Поздняковым (1961). Горная растительность изучены Т.А Работновым (1937), А.М. Бойченко (1992), К.А. Волотовским (1992), В.Н. Андреева и др. (1987), П.А. Тимофеевым (1980), И.П. Щербаковым (1975), П.А. Тимофеевым и другими (1994). Биоразнообразие Токкинского Становика отражено в работе Чевычелова А.П. и других (2010).

Растительный покров территории формируется в условиях лучшей обеспеченности теплом при большем количестве осадков на плоскогорном рельефе и в условиях сглаженности континентальности климата. Распределение растительности обусловлено горными условиями территории. Рельеф Нерюнгринского района представлен восточной частью Алданского нагорья, Алдано-Учурским и Сутано-Гонамским хребтами, Сутамо-Нингамским среднегорьем, Токинской горной равниной и Алгамской котловиной со средними высотами 800-1600 м над у. м.

Территория разреза «Нерюнгринский» как и город Нерюнгри расположен в Чульманской впадине, ее морфоструктура оформилась под влиянием нивального выравнивания и криогенных солифлюкционных процессов, с чем связано широкое распространение мощных каменных плащей, курумов, нагорных террас, каров и наледей.

Горы Южной Якутии произрастают горными мохово-кустарничковыми и кустарниковыми лиственничными, сосновыми, сосново-лиственничными и смешанными с темнохвойными лесами с участками горной лесотундры и пятнами зарослей подгольцовых кустарников. Растительность распределяется высотными поясами: пониженные участки гор до высоты 650-900 м заняты горными среднетаежными лесами, а выше идут редкостойные горные лесотундровые леса, сменяющиеся с высоты 1400 м высокогорной растительностью (Скрябин, Караваев, 1991). 


\section{С.И. Миронова, В.В. Иванов}

Растительность района относится к Учурскому горному среднетаежному округу южно-якутской провинции сосново-лиственничной тайги с участием темнохвойных лесов (Леса среднетаежной.., 1994). Лесообразующей породой является лиственница Каяндера, значительное место в древостоях принадлежит сосне обыкновенной и ели сибирской и аянской. Лесистость составляет $75 \%$.

Лиственничные леса занимают $70 \%$ территории и широко распространены от сухих до сырых местопроизрастаний. По площади второе место занимают насаждения кедрового стланика. Характерными типами являются лиственничники брусничные зеленомошные, багульниковые, багульниково-моховые, мелколистнорододендрово-моховые, а также горные лиственничники с кедровым стлаником и березкой растопыренной. Типологический состав также богат - от толокнянковых до рододендроново-и можжевельниково-брусничных.

Сосняки брусничные и толокнянковые занимают $7 \%$ от общего состава лесов, а кедровостланиковые заросли $-12 \%$.

На карбонатных породах из известняков и доломитов господствуют лиственничные и сосновые леса с высокой продуктивностью и флористическим богатством (Щербаков, 1964, 1975; Волотовский, 1992, Разнообразие..., 2005). Возвышенные сухие участки заняты разреженными сосновыми и лиственничными лесами с кустарниковым подлеском из рододендрона, кизильника, таволги, шиповника, можжевельника и жимолости. В нижних ярусах преобладают арктоус, лимнас, толокнянка и реже дриада. На хорошо увлажненных почвах формируются смешанные леса с богатым видовым составом (лиственница, ель, сосна, береза плосколистная, осина, рябина). Подлесок изобилует можжевельником, ольховником, березой, ивами, с брусникой и голубикой в нижнем ярусе.

Переувлажненные участки занимают голубично-моховые лиственничники с примесью ели. На карбонатах часто встречаются елово-лиственничные леса, а на проточно-переувлажненных распадках - разнотравно-зеленомошные еловые редколесья.

Березовые и осиновые леса имеют постпожарное происхождение и встречаются часто в виде примеси в древостоях других формаций, в частности в лиственничных брусничных, багульниковых или голубичных лесах.

У верхнего предела леса и по горным распадкам встречаются бруснично-зеленомошные ельники из ели сибирской и аянской. Ель аянская часто входит в состав лиственничников на кристаллических породах в качестве примеси в древостоях и в подросте.

Прирусловые узкие участки рек и речек заняты зарослями ив, тополя, чозении, березы кустарниковой и таволги. 
Чульманское плоскогорье имеет типично расчлененный рельеф с местными базисами эрозии в пределах 100-200 м с преобладанием выпукло-склоновых местоположений с крутизной 4-10. Сама впадина делится на 2 половины:

1) более пониженная (950 м) - бассейны рек Чульман и Горбыллах;

2) приподнятая Унгро-Якокитская впадина.

Горное расположение района определяет поясность всех составляющих ландшафтов, в том числе и растительности. На высоте 1100-1300 м распространены горные тундры (скалы, курумы), а с 1000-1100 м начинается граница тундрогольцовой растительности и тайга

В верхней зоне тайги, с высоты 900-1100 м встречается лиственничное редколесье с кедровым стлаником. На повышениях обычна бруснично-лишайниковая тундра из кедрового стланика и березы тощей на подзолистых почвах и подбурах. Кроме лиственницы, произрастают ольховник кустарниковый, береза Миддендорфа, в травяно-кустарничковом ярусе - багульник, голубика, шикша, арктоус, редко видна осока кругловатая. На оподзоленных остаточно-карбонатных подбурах развиваются лиственничники голубично-брусничные $(0,3-0,4)$ с ивами, можжевельником, в травяном покрове не часты осока и ветреница.

На высоте 500-700 м преобладают среднетаежные леса, представленные сосново-лиственничными (8Л2С) лишайниковыми типами на подзолистых почвах или лиственнично-сосновые багульниково-лишайниковые типы на террасах на типичных подзолистых иллювиально-гумусовых почвах. По покатым участкам водоразделов развиты сосново-лиственничные моховые леса с березой и ольховником в подлеске и голубикой и багульником на мерзлотно-таежных почвах.

Ниже 500 м господствуют багульниково-моховые лиственничники на мерзлотных перегнойно-карбонатных почвах низких водоразделов. Кустарники представлены березой, ольховником, из кустарничков развита голубика на моховом покрове из мха плеурозиума и сфагнума.

По долинам крупных и малых рек на мерзлотных болотных почвах произрастают лиственничники редкостойные с елью кустарниково-моховой из березы тощей и аулокомниума. По руслам и поймам рек и речек узкими полосками растут разнотравно-злаковые и злаково-осоковые сообщества на мерзлотных пойменных почвах.

\section{2. Техногенная раститедьность}

Разрез «Нерюнгринский» расположен на водоразделе речек Верхний Нерюнгри и Нижний Нерюнгри (притоки р. Чульман), а русло р. Холодникан проходит под отвалами карьера. 


\section{С.И. Миронова, В.В. Иванов}

Естественная растительность представлена голубично-ерниково-сосново-лиственничными сообществами на повышенных местообитаниях и голубично-брусничными кедровостланиково-лиственничными - на пониженных участках.

Растительность вокруг карьера и нарушенных участков испытывает значительное воздействие человека. Во-первых, в местах добычи угля и отсыпки отвалов (карьер, внутренние и внешние отвалы, промплощадки, дороги) почвенно-растительный покров полностью уничтожен без селективной отсыпки. Во-вторых, окружающая карьер растительность испытывает загрязнение пылью, не желательными для организма растений микроэлементами, в том числе тяжелыми металлами, что приводит к внутренним и внешним изменениям в органах растений.

Окружающая разрез естественная растительность испытывает влияние промышленного комплекса. Наблюдается загрязнение пылью и его оседание на органы кустарничково-травянистых растений и деревьев, а также поглощение ими не желательных загрязняющих веществ (микроэлементов и тяжелых металлов).

Исследования в других регионах России показывают, что влияние атмосферных загрязнений вызывает в первую очередь изменение ботанического состава растительных сообществ, особенно лишайниковых синузий - тонких индикаторов уровня загрязнения. Так, разрушение лесной растительности происходит при сильных воздействиях эмиссий азотных комбинатов, когда виды лесных сообществ сменяются рудеральными, а при достаточном увлажнении - луговыми видами (Миркин, 1984). При повышении концентрации сернистого газа наблюдается смена хвойных пород лиственными видами (береза, ольха, ивы и др.).

Вблизи промышленных предприятий обычно наблюдаются понижение биохимической и микробиологической активности почвенно-растительного покрова, увеличение кислотности, уменьшение поглощенных оснований и степени насыщенности основаниями. Повышение кислотности почвы связано с образованием в ней серной кислоты за счет абсорбируемого сернистого газа. Под воздействием значительных концентраций вредных газов, особенно двуокиси серы и фтора, в растениях нарушается углеродно-азотный режим, разрушаются хлоропласты и хлорофилл, что проводит к нарушению роста и развития растений. Даже невысокие концентрации промышленных газов влияют на физиологические функции, снижая, например, интенсивность транспирации почти в 1,5-2 раза. А у деревьев в верхней части кроны она падает быстро и верхушки побегов подсыхают. Значительное повышение концентрации вредных веществ в клеточном соке органов растений может вызвать 
«острую реакцию» - некрозы участков листа. Деревья и кустарники, задерживая газы и пыль, сами подвергаются вредному их влиянию в зависимости от степени своей устойчивости, а также от других экологических факторов.

При всех равных условиях (структура леса, метеорологические факторы и др.) наиболее эффективными в очистке воздуха от вредных примесей являются чистые лиственные насаждения, за ними идут смешанные хвойно-лиственные и затем - хвойные. Угнетение роста и развития зависит от чувствительности породы: из хвойных пород сильнее всего подавляется рост у лиственницы (в охвоенном состоянии), несколько меньше у ели, а из лиственных - сильнее проявляется у осины. Воздействие вредных газов неблагоприятно сказывается и на развитии корневой системы: сильно снижается общая масса корней, а физиологически активных корней становится в 2-4 раза меньше, чем у не поврежденных растений.

Увеличение мощности разреза «Нерюнгринский» не повлечет за собой отчуждения площадей почвенно-растительного покрова, но увеличит воздействие загрязнителей атмосферного воздуха и через него растительности.

Степень нарушения растительности зависит от длительности действия фактора загрязнения, причем, разные виды угнетаются в разной степени - могут полностью исчезать или снижать свою численность.

Лесистость составляет $75 \%$. Доминируют лиственничные леса от сухих до сырых местопроизрастаний (70\%),

В лесном покрове господствуют лиственничные леса сырых и средневлажных местопроизрастаний (70\%). Типологический состав и производительность их очень разнообразны. Характерными типами являются лиственничники бруснично-зеленомошные, багульниковые, багульниково-моховые, рододендроново (рододендрон мелколистный), моховые, горные лиственничники с кедровым стлаником, березкой растопыренной.

Типологический состав также богат - от толокнянковых до рододендроново (Р. даурский) и можжевельниково-брусничных. Брусничные и толокнянковые сосняки занимают $7 \%$ от общего состава лесов, кедровостланиковые заросли $-12 \%$.

Особенностью лесного покрова являются бруснично-зеленомошные ельники из ели сибирской и аянской, встречающиеся у верхнего предела леса и по горным распадкам. Ель аянская часто входит в состав лиственничников на кристаллических породах в качестве примеси в древостоях и в подросте. 


\section{С.И. Миронова, В.В. Иванов}

Береза шерстистая и кедровый стланик имеют более широкое распространение, чем в Алданском округе. Округ также отличается отсутствием кедра и пихты.

Степень устойчивости сообщества к антропогенным воздействиям принято называть их антропогенной толерантностью. Работ по антропотолерантности достаточно много, однако, они не носят количественного характера. Определение предельно допустимых нагрузок разных антропогенных факторов на разные сообщества является актуальной задачей изучения динамики растительности.

Для сравнительной оценки влияния антропогенных факторов вне зависимости от их природы существует мера - нагрузка фактора, которая определяется изменением (снижением) а-разнообразия (альфаразнообразия) сообществ. Загрязнения (атмосферные, почвенные, водной среды и др.) могут быть факторами нарушений и причинами гейтогенетических сукцессий. Степень нарушения растительности зависит от длительности действия фактора загрязнения, причем, разные виды угнетаются в разной степени - могут полностью исчезать или снижать свою численность.

Влияние атмосферных загрязнений вызывает в первую очередь изменение ботанического состава растительных сообществ, особенно лишайниковых синузий, что делает их тонкими индикаторами уровня загрязнения. Так, разрушение лесной растительности происходит при сильных воздействиях эмиссий азотных комбинатов, когда на смену видам лесных сообществ приходят рудеральные и при достаточном увлажнении - луговые виды (Миркин, 1984). При повышении концентрации сернистого газа наблюдается смена хвойных пород лиственными видами (береза, ольха, ивы и др.).

В зоне влияния Нерюнгринского промышленного комплекса растительный покров также является ведущим индикатором изменения состояния природной среды. Во-первых, в местах добычи угля и отсыпки отвалов растительность полностью уничтожена. Причем селективной отсыпки не видно. Во-вторых, окружающая карьер растительность испытывает загрязнение пылью, не желательными для организма растений микроэлементами, в том числе тяжелыми металлами.

Анализ литературы показывает, что вблизи промышленных предприятий обычно наблюдаются понижение их биохимической и микробиологической активности почвенно-растительного покрова, увеличение кислотности, уменьшение поглощенных оснований и степени насыщенности основаниями. Повышение кислотности почвы связано с образованием в ней серной кислоты за счет абсорбируемого сернистого газа. 
Под воздействием значительных концентраций вредных газов, особенно двуокиси серы и фтора, в растениях нарушается углеродноазотный режим, разрушаются хлоропласты и хлорофилл, что проводит к нарушению роста и развития растений. Даже невысокие концентрации промышленных газов влияют на физиологические функции, снижая, например, интенсивность транспирации почти в 1,5-2 раза. А у деревьев в верхней части кроны она падает быстро и верхушки побегов подсыхают. Значительное повышение концентрации вредных веществ в клеточном соке органов растений может вызвать «острую реакцию» - некрозы участков листа.

Деревья и кустарники, задерживая газы и пыль, сами подвергаются вредному их влиянию в зависимости от своей устойчивости, а также от других экологических факторов. При всех равных условиях (структура леса, метеорологические факторы и др.) наиболее эффективными в очистке воздуха от вредных примесей являются чистые лиственные насаждения, за ними идут смешанные хвойно-лиственные и затем - хвойные. Угнетение роста и развития зависит от чувствительности породы: из хвойных пород сильнее всего подавляется рост у лиственницы (охвоенном состоянии), несколько меньше у ели, а из лиственных - сильнее у осины.

Воздействие вредных газов неблагоприятно сказывается и на развитии корневой системы: сильно снижается общая масса корней, а физиологически активных корней становится в 2-4 раза меньше, чем у не поврежденных растений. 


\section{ГАава 4. ТЕХНОГЕННЫЕ ИЗМЕНЕНИЯ РАСТИТЕЛЬНОСТИ В РЕГИОНЕ}

Изучение техногенной трансформации растительности в зоне влияния разреза «Нерюнгринский» проведено в составе комплексной экологической экспедиции Институт прикладной экологии Севера автором и Кудиновой 3.А. с 2004 года с дальнейшими опытно-экспериментальными работами по биологической рекультивации отвалов разреза.

До разработки месторождения угля естественная растительность была представлена лиственничными лесами сырых и средневлажных местообитаний с доминированием бруснично-зеленомошных, багульниково-моховых, рододендрово-моховых типов в водоразделах и горными лиственничниками с кедровым стлаником и березой растопыренной (Леса среднетаежной..., 1994).

Добыча угля открытым способом привела к значительным изменениям в растительном покрове и в количественном и в качественном отношении. В первую очередь изменения заметны в ботаническом составе растительности.

\section{Изменение в видовом составе растительности}

Степень нарушения растительности зависит от длительности действия фактора загрязнения, причем, разные виды угнетаются в разной степени - могут полностью исчезать или снижать свою численность. Определение предельно допустимых нагрузок разных антропогенных факторов на определенные виды и сообщества является актуальной задачей в изучении динамики растительности. Для сравнительной оценки влияния антропогенных факторов вне зависимости от их природы существует мера - нагрузка фактора, которая определяется изменением (снижением) а-разнообразия (альфа-разнообразия) сообществ. Загрязнения (атмосферные, почвенные, водной среды и др.) могут быть факторами нарушений и причинами гейтогенетических сукцессий (Миркин, 1984).

Как известно, естественные растительные сообщества в отличие от искусственных цензов устойчивы во времени (Шарашова, 1989). Под влиянием различных факторов растительный мир скудеет, теряет свою первооснову, наблюдается ускорение процессов эрозии и дигрессионная смена растительности. Характерная черта большинства комплексных систем - резкий переход от стабильности к нестабильности. 
В первую очередь, изменение ботанического состава растительных сообществ, особенно лишайниковых синузий, происходит при загрязнении атмосферы, что делает их тонкими индикаторами уровня загрязнения. Так, разрушение лесной растительности происходит при сильных воздействиях эмиссий азотных комбинатов, когда на смену лесным видам приходят рудеральные, а при достаточном увлажнении - луговые виды (Миркин, 1984).

Степень антропогенной, в частности техногенной, трансформации лесной растительности зависит от типа леса.

В хвойных лесах (сосновых и лиственничных) характерна, в целом, негативная трансформация:

- снижение жизненного состояния лесообразующих пород, выпадение из видового состава низших растений грибов-кальцефобов (груздь, подберезовик, масленок, лисичка), образующих микоризу с корнями древесных пород;

- ухудшение вкусовых качеств и деформации плодов у отдельных видов (смородина, шиповник);

- некоторое увеличение морфологических аномалий и заболеваемости отдельных видов растений (гигантизм, болезни, вредители).

В травяном и травяно-кустарничковом ярусе происходит также выпадение более чувствительных видов-кальцефобов (черника, брусника, грушанка, ожика, плаун) и увеличение роли других из семейств бобовые, орхидные, мятликовые.

Анализ литературы показывает, что вблизи промышленных предприятий обычно наблюдаются понижение их биохимической и микробиологической активности почвенно-растительного покрова, увеличение кислотности, уменьшение поглощенных оснований и степени насыщенности основаниями. Повышение кислотности почвы связано с образованием в ней серной кислоты за счет абсорбируемого сернистого газа. Под воздействием значительных концентраций вредных газов, особенно двуокиси серы и фтора, в растениях нарушается углеродно-азотный режим, разрушаются хлоропласты и хлорофилл, что проводит к нарушению роста и развития растений. Даже невысокие концентрации промышленных газов влияют на физиологические функции, снижая, например, интенсивность транспирации почти в 1.5-2 раза. А у деревьев в верхней части кроны она падает быстро и верхушки побегов подсыхают. Значительное повышение концентрации вредных вешеств клеточного сока органов растений может вызвать «острую реакцию» - некрозы участков листа.

Деревья и кустарники, задерживая газы и пыль, сами подвергаются вредному их влиянию в зависимости от своей устойчивости, а также 
от других экологических факторов. При всех равных условиях (структура леса, метеорологические факторы и др.) наиболее эффективными в очистке воздуха от вредных примесей являются чистые лиственные насаждения, за ними идут смешанные хвойно-лиственные и затем - хвойные. Угнетение роста и развития зависит от чувствительности породы: из хвойных пород сильнее всего подавляется рост у лиственницы (в освоенном состоянии), несколько меньше у ели, а из лиственных - сильнее у осины.

Воздействие вредных газов неблагоприятно сказывается и на развитии корневой системы: сильно снижается общая масса корней, а физиологически активных корней становится в 2-4 раза меньше, чем у не поврежденных растений.

Растительность в зоне влияния Нерюнгринского промышленного комплекса также претерпела изменения. Во-первых, в местах добычи угля и отсыпки отвалов растительность полностью уничтожена. Вовторых, окружающая карьер растительность испытывает загрязнение пылью, не желательными для организма растений микроэлементами, и в первую очередь тяжелыми металлами.

Нами на определенных точках изучено изменение структуры растительного покрова, в частности видового состава и сходства видов сообшеств. Изменению видового разнообразия растений дает возможность установить степень деградации растительного покрова под воздействием антропогенных факторов. При этом объективные результаты дают методы изучения динамики растительности, особенно прямые - наблюдения на постоянных квадратах.

Одним из прямых методов реакции растений на фактор нарушения является количественный градиентный анализ - вариант прямого градиентного анализа, разработанный в 60-х годах в г. Уфе (Миркин, Розенберг, 1978). Для анализа используются различные градиенты: отдельных экологических факторов (анализ экоклинов), пространственные (анализ топоклинов), сукцессионные (анализ хроноклинов). Он слагается из следующих этапов: построение эмпирического распределения встречаемости вида в нескольких градациях фактора среды, выбранного в качестве оси ординации, проверка достоверности одновершинного характера этого распределения с использованием критерия Стьюдента.

Изменение видового состава растений нами изучены методом ординации (распределение видов вдоль фактора среды). Наиболее подходящим в условиях действия Нерюнгринского разреза является анализ экоклинов (градиент-загрязнение). Площадки нами выбраны на основе аэрокосмических съемок с наложением альбедо снега, при котором были четко определены зоны сильного, среднего и слабого загрязнения 
пылью. В связи с этим выбрано 3 участка описания растительности. На данных участках выборка описаний проведена на площади $10 \times 10$ м. На территории каждого участка выполнено по 50 описаний, всего - 150 (Миронова, 2000; Миронова, Кудинова, 2009, 2012). На камеральном этапе составлялась валовая таблица, при помощи которой подсчитывалась встречаемость каждого вида в описаниях - видовое богатство (альфа-разнообразие).

Участок 1 заложен недалеко от разреза, прямо за отвалами пустых пород, на склоне коренного берега р. Нерюнгри.

Растительность представлена багульниково-брусничным лиственничным лесом в примеси с кедровым стлаником и сосной (табл. 4.1). Первый ярус леса состоит из лиственницы Гмелина, сосны обыкновенной, в подлеске встречаются кедровый стланик, береза плосколистная и Миддендорфа. В кустарничковом ярусе господствуют брусника, багульник, голубика, шикша. Проективное покрытие лишайниково-мохового покрова в зависимости от степени вытаптывания находится в пределах 10-50\%.

Участок № 2 находится в долине р. Горбылах в 10 км юго-востоку от разреза. В растительности доминирует лишайниково-голубично-багульниковый с ольховником сосново-лиственничный лес с примесью кедрового стланика. Лес сравнительно молодой, закустаренный. Первый ярус представлен лиственницей, сосной, в подлеске много кустарников из березы, ольхи, кедрового стланика. Кустарничковый ярус сплошной, где в равной степени растут брусника, голубика, багульник. Мохово-лишайниковый ярус более развит, чем на первом участке, особенно лишайниковый.

Состояние леса нормальное, хотя и здесь были разработки: срубленные и засохшие деревья.

Участок № 3 заложен в долине р. Иенгра, в ее устьевой части (впадение р. Сыгынах) в более 70 км от разреза. Преобладает мохово-голубично-брусничный лиственничный лес. В подлеске много березы Миддендорфа, часто встречается кедровый стланик. Лес спелый, нормально развитый. Заметны следы трактора, где произрастают осоки и ерники.

Результаты ординации представлены в табл. 4.1.

К группе сквозных видов относятся основном лесные виды.

Первый участок - самый ближний к карьеру лесной участок отличается большим разнообразием видов (29 видов). Появление в лесных сообществах разнотравья - кипрея узколистного (иван-чая), соссюреи, видов осок и злаков (вейник) - показывает негативное влияние эндогенных факторов (рубка деревьев, вытаптывание или изменение экологических условий для лесных видов). На месте уничтоженных деревьев появляются кустарники (можжевельник, шиповник, ерники), меняется и проективное покрытие мохово-растительного покрова - он изреживается, местами 
оголяется. Влияние разреза заметна и на структуре леса. Растительный покров находится в угнетенном состоянии: видны тропинки, следы кострищ, много срубленных деревьев, видна суховершинность у деревьев.

Та бли ца 4.1

Экоклин растительности в зоне влияния Нерюнгринского разреза

\begin{tabular}{|c|c|c|c|}
\hline Название видов & $\begin{array}{c}1 \\
\text { (у раз- } \\
\text { реза) }\end{array}$ & $\begin{array}{c}2 \\
\text { (р. Гор- } \\
\text { былах) }\end{array}$ & $\begin{array}{c}3 \\
\text { (p. Сы- } \\
\text { гынах) }\end{array}$ \\
\hline 1 & 2 & 3 & 4 \\
\hline \multicolumn{4}{|l|}{ Сквозные виды } \\
\hline Larix gmelinii - Лиственница Гмелина & 25 & 25 & 25 \\
\hline Pinus pumila - Кедровый стланик & 23 & 22 & 9 \\
\hline Ledum palustre - Багульник болотный & 22 & 25 & 25 \\
\hline Pinus sylvestris - Сосна обыкновенная & 13 & 25 & 10 \\
\hline Vaccinium uligunosum - Голубика & 21 & 25 & 25 \\
\hline Vaccinium v-ideae - Брусника & 24 & 24 & 24 \\
\hline Мхи & 19 & 12 & 24 \\
\hline Лишайники & 15 & 24 & 23 \\
\hline Betula middendorffii - Береза Миддендорфа & 9 & 24 & 25 \\
\hline \multicolumn{4}{|c|}{ Виды, характеризующие антропогенное воздействие } \\
\hline Carex sp. - Осока & 6 & 1 & 23 \\
\hline Empetrum nigrum - Шикша черная & 13 & 6 & \\
\hline Calamagrostis langsdorffii - Вейник Лангсдорфа & 7 & 4 & \\
\hline Duschekia fruiticosa - Ольховник кустарниковый & 6 & 6 & \\
\hline Rosa acicularis - Шиповник щетинистый & 9 & 1 & \\
\hline Juniperus sibirica - Можжевельник сибирский & 8 & 6 & \\
\hline Atragene sibirica - Княжик сибирский & 6 & & \\
\hline Chamerion angustifolium - Кипрей узколистный & 10 & & \\
\hline Saussurea sp. - Соссюрея & 11 & & \\
\hline Pyrola incarnata - Грушанка & 8 & & \\
\hline Lonicera altaica - Жимолость алтайская & 4 & & \\
\hline Picea obovata - Ель обыкновенная & 2 & & \\
\hline Betula platiphylla - Береза плосколистная & 3 & & \\
\hline
\end{tabular}


Окончание табл. 4.1

\begin{tabular}{|l|c|c|c|}
\hline \multicolumn{1}{|c|}{1} & 2 & 3 & 4 \\
\hline Salix sp. - Ива & 3 & & 2 \\
\hline Chosenia arbutifolia - Чозения крупночешуйчатая & 2 & & \\
\hline Spiraea теdia - Таволга средняя & 2 & & \\
\hline Hedysarum sp. - Копеечник & 1 & & \\
\hline Campanula langsdorfiana - Колокольчик Лангдорфа & 1 & & \\
\hline Leontopodium antenпагіoides - Эдельвейс & 1 & & \\
\hline Pedicularis sp. - Мытник & & 1 & \\
\hline Linnaea borealis - Линнея северная & & 1 & \\
\hline Poa sp. - Мятлик & & & 1 \\
\hline Eriophorum sр. - Пушица & & & 13 \\
\hline Всего видов & 29 & 17 & \\
\hline
\end{tabular}

На втором участке в 10 км от карьера в отличие от первой количество видов сократилось до 17. Господствуют лесные видов, уменьшилась доля разнотравья и увеличилась участие в растительном покрове лишайников и мхов.

Третий участок - самый дальний и менее подвержен влиянию горных работ. Как показала ординация видов, видовое разнообразие еще уменьшено до 13 с преобладанием лесных видов и высоким проективным покрытием мхов и лишайников.

Степень устойчивости жизненного состояния растений, видового состава и структуры основных фитоценозов можно определить по степени гемеробности ландшафта (степень окультуренности или нарушенности) (Волкова, Давыдова, 1987). Для этого нами проводились геоботанические описания участков разной степени нарушенности с оценкой по шкале гемеробности от не нарушенных (агемеробных) к слабо- (олиго-), средне- (мезо-), сильно- (поли-) и сверхнарушенным (гипергемеробным).

Уровень гемеробности определен по комплексу признаков: по общему проективному покрытию, изменению видового состава, ярусности, участия травянистых (рудеральных) видов. На основе 6-ибальной шкалы гемеробности Виларда-Mарра (Willard, Marr, 1970) и уровней гемеробности Зукоппа (1981) составлена 3-бальная шкала гемеробности (табл. 4.2) 
Таблица 4.2

Характеристика растительности по уровне гемеробности

\begin{tabular}{|c|c|c|c|}
\hline $\begin{array}{c}\text { Уровни } \\
\text { гемеровности }\end{array}$ & Баллы & $\begin{array}{l}\text { Проективное } \\
\text { покрытие, \% }\end{array}$ & Признаки воздействия \\
\hline $\begin{array}{l}\text { Агемеробные } \\
\text { и олигогемероб- } \\
\text { ные }\end{array}$ & $0-1$ & $85-100$ & $\begin{array}{l}\text { Воздействие незначительное, рас- } \\
\text { тительность до } 90 \% \text { естественная, } \\
\text { незначительное обеднение видового } \\
\text { состава, структура сообществ почти не } \\
\text { нарушается, наблюдается лишь неко- } \\
\text { торое изреживание ярусов травостоя }\end{array}$ \\
\hline Мезогемеробные & 2 & $30-85$ & $\begin{array}{l}\text { Экосистема подверглась изменению, } \\
\text { жизненность растений ослаблена, } \\
\text { имеются рудеральные сообщества, } \\
\text { почвы местами смыты в результате } \\
\text { эрозии. Угнетенность жизненного } \\
\text { состояния древостоя, подлеска и под- } \\
\text { роста, существенным изменением } \\
\text { в видовом составе и структуре траво- } \\
\text { стоя, появлением луговых трав }\end{array}$ \\
\hline $\begin{array}{l}\text { Поли- и гипер- } \\
\text { гемеробные }\end{array}$ & 3 & До 30 & $\begin{array}{l}\text { Естественная растительность } \\
\text { уничтожена или сильно подавлена, } \\
\text { сохраненность до } 5 \% \text {, начальные } \\
\text { стадии самозарастания Полностью } \\
\text { угнетаются все яруса, от древесного до } \\
\text { травяно-мохового. В структуре траво- } \\
\text { стоя происходит смена эдификаторов } \\
\text { и доминантов всех ярусов, нарушается } \\
\text { лесная подстилка, а местами она во- } \\
\text { обще исчезает }\end{array}$ \\
\hline
\end{tabular}

Установлено, что при переходе с одного уровня гемеробности к другому растительность претерпевает значительные изменения как в видовом составе так и структуре сообществ.

\section{1. Изменения в дишайниковом покрове}

Лишайники изучены 3.А. Кудиновой.

Лишайники являются неотъемлемым компонентом растительных сообществ. Изучение лишайников как индикаторов загрязнения воздуха в городах и промышленных районах имеет огромное значение в связи с проблемой охраны окружающей среды. Они считаются традиционным объектом экологического мониторинга и биоиндикации загрязнения окружающей среды. 
Изучаются разные признаки лишайникового покрова, и выводы делаются на основе анализа, как всего комплекса учитываемых показателей, так и выявленных изменений только одного признака. Данные базируются на сравнительном изучении видового состава лишайников, формируемых ими группировок, распространении отдельных видов, морфологических изменений слоевищ, физиологических показателей, прироста, концентрации загрязнителей в слоевищах и другие.

Изменение видового состава лишайников. При геоботаническом исследовании территории нами выявлено 39 видов лишайников из 7 семейств, 13 родов (табл. 4.3). Ведущими семействами являются Cladoniaceae и Parmeliaceae, наибольшее количество видов представлено из рода Cladonia.

Таблица 4.3

Список лишайников окрестностей г. Нерюнгри

\begin{tabular}{|c|c|c|}
\hline Семейство & Род & Вид \\
\hline 1 & 2 & 3 \\
\hline \multirow{2}{*}{$\begin{array}{l}\text { Alectoriaceae } \\
\text { (Hue) Thomas }\end{array}$} & Alectoria Ach. & Alectoria ochrolenuca (Hoffm.) Mass. \\
\hline & $\begin{array}{l}\text { Bryoria Brodo } \\
\text { \& D. Hawksw }\end{array}$ & $\begin{array}{l}\text { Bryoria simplicior (Vain.) Brodo \& D. Hawksw. } \\
\text { Bryoria implexa (Hoffm.) Brodo \& D. Hawksw }\end{array}$ \\
\hline $\begin{array}{l}\text { Cladoniaceae } \\
\text { Zenker }\end{array}$ & $\begin{array}{l}\text { Cladonia Hill } \\
\text { ex P. } \\
\text { Browne }\end{array}$ & $\begin{array}{l}\text { Cladonia stellaris (Opiz.) Brodo. } \\
\text { Cladonia amaurocraea (Flörke) Schaer. } \\
\text { Cladonia gracilis (L.) Willd. } \\
\text { Cladonia deformis (L.) Hoffm. } \\
\text { Cladonia uncialis (L.) Weber ex F.H. Wigg. } \\
\text { Cladonia phyllophora Hoffm. } \\
\text { Cladonia furcata (Huds.) Schrad. } \\
\text { Cladonia coccifera (Flörke) Spreng. } \\
\text { Cladonia rangiferina (L.) Nyl. } \\
\text { Cladonia arbuscula (Wallr.) Hale \& W.L. Culb. } \\
\text { Cladonia chlorophaea (Flörke ex Sommerf.) } \\
\text { Cladonia bacilliformis (Nyl.) Glück. } \\
\text { Cladonia mitis (Sandst.) Hustich }\end{array}$ \\
\hline \multirow[t]{3}{*}{$\begin{array}{l}\text { Parmeliaceae } \\
\text { Zenker }\end{array}$} & Cetraria Ach. & $\begin{array}{l}\text { Cetraria cucullata (Bellardi) Ach. } \\
\text { Cetraria laevigata Rassad. } \\
\text { Cetraria seliaris }\end{array}$ \\
\hline & Evernia Ach. & $\begin{array}{l}\text { Evernia esorediosa (Mull. Arg.) D.R. } \\
\text { Evernia divaricata (L.) Ach. } \\
\text { Evernia mesomorpha } \mathrm{Nyl}\end{array}$ \\
\hline & $\begin{array}{l}\text { Hypogymnia } \\
\text { (Nyl.) Nyl. }\end{array}$ & $\begin{array}{l}\text { Hypogymnia physodes (L.) Nyl. } \\
\text { Hypogymnia bitteri (Lynge) Ahti }\end{array}$ \\
\hline
\end{tabular}


Окончание табл. 4.3

\begin{tabular}{|c|c|c|}
\hline 1 & 2 & 3 \\
\hline \multirow[t]{3}{*}{$\begin{array}{l}\text { Parmeliaceae } \\
\text { Zenker }\end{array}$} & Parmelia Ach. & $\begin{array}{l}\text { Parmelia sinuosa }(\mathrm{Sm} .) \text { Ach. } \\
\text { Parmelia omphalodes (L.) Ach. } \\
\text { Parmelia centrifuga (L.) Ach. } \\
\text { Parmelia olivaceae (L.) Ach., em Nyl. } \\
\text { Parmelia sulcata Taylor }\end{array}$ \\
\hline & $\begin{array}{l}\text { Parmeliopsis } \\
\text { (Nyl.) Nyl }\end{array}$ & $\begin{array}{l}\text { Parmeliopsis hyperopta (Ach.) S.L.F. Meyer. } \\
\text { Parmeliopsis ambigua (Wulfen.) S.L.F. Meyer }\end{array}$ \\
\hline & $\begin{array}{l}\text { Vulpicida Mattson } \\
\text { \& M.J. Lai }\end{array}$ & Vulpicida pinastri (Scop.) J.-E. Mattson et Lai \\
\hline $\begin{array}{l}\text { Ramalinaceae } \\
\text { C. Agardh }\end{array}$ & Ramalina Ach. & Ramalina sp. \\
\hline $\begin{array}{l}\text { Stereocaulaceae } \\
\text { Chevall. }\end{array}$ & $\begin{array}{l}\text { Stereocaulon } \\
\text { Hoffm. }\end{array}$ & $\begin{array}{l}\text { Stereocaulon paschale Hoffm. } \\
\text { Stereocaulon wrigthii Fuck. } \\
\text { Stereocaulon glareosum (Savicz.) H. Magn }\end{array}$ \\
\hline $\begin{array}{l}\text { Nephromataceae } \\
\text { Wetm. ex J.C. } \\
\text { David \& O.E. } \\
\text { Erikss. }\end{array}$ & Nephroma Ach. & Nephroma arcticum (L.) Torss. \\
\hline
\end{tabular}

Распределение видов лишайников по географическим элементам и типам ареалов показало, что основу лихенофлоры окрестностей г. Нерюнгри составляет бореальный элемент, а также отмечены мультизональный, монтанный и арктоальпийский элементы. По типам ареала преобладает мультирегиональный, незначительное участие принимает голарктический тип.

При изучении изменения состава лишайников в зависимости от отдаленности от объекта загрязнения (карьера) за основу приняты результаты геохимического анализа почв (Тарабукина, 1996) и загрязнения снежного покрова (Артамонова и др., 2000; Иванов, 2005).

Нами выделены следующие зоны:

1 - зона сильного воздействия - до 5 км к юго-востоку от карьера;

2 - зона среднего воздействия - в 5-30 км от карьера;

3 - зона слабого воздействия - более 30 км от карьера.

В каждой зоне нами проводилось описание лесной растительности и сообществ эпифитных и эпигейных лишайников в 5-ти повторностях. Расстояние между площадками составляет 500 м, размер площадки $25 \times 25$ м. 
Первая зона находится южнее угольного разреза «Нерюнгринский», на правом берегу р. Верхняя Нерюнгри и представляет собой пологий склон коренного берега реки.

Древостой сложен из лиственницы (Larix cajanderi) с небольшой примесью сосны и березы. Средняя высота лиственницы 20 м, средний диаметр стволов $20 \mathrm{~cm}$, сомкнутость крон 0,4 . Подлесок слабо развит (10\%), в основном представлен березой, кедровым стлаником, душекией, в небольшом количестве встречаются можжевельник, шиповник, изредка ивы, таволга и кизильник. В травяно-кустарничковом покрове с проективным покрытием $50 \%$, преобладают голубика, брусника, багульник, местами произрастает шикша, из разнотравья (проективное покрытие 3-5\%) отмечены лимнас, грушанка, соссюрея, иван-чай, колокольчик, аконит, хвощ, княжек и злаки. Моховолишайниковый покров занимает $60 \%$, преобладают мхи, лишайники занимают в среднем $25 \%$.

Вторая зона выбрана к юго-западу от карьера на левом берегу р. Чульман, рельеф - пологий склон сопки.

Древостой состоит из лиственницы без примеси, средняя высота деревьев $20 \mathrm{M}$, средний диаметр $18 \mathrm{~cm}$, сомкнутость 0,3 . Подлесок развит, разнопородный, проективное покрытие $30 \%$, преобладают береза, кедровый стланник (покрытие $20 \%$ ), также произрастают душекия, шиповник, ивы, единично отмечен курильский чай. Травяно-кустарничковый покров занимает $60-75 \%$, доминируют голубика, брусника, содоминируют багульник и злаки. Из трав встречаются соссюрея, грушанка, иван-чай, астрагалы, хвощ. Моховой покров почти сплошной $70 \%$, лишайники занимают $30-40 \%$.

Третья зона находится юго-западнее угольного разреза на левобережном склоне р. Чульман.

Доминирует лиственничник с примесью березы и сосны, средняя высота лиственницы составляет $20 \mathrm{M}$, диаметр - $25 \mathrm{~cm}$, сомкнутость крон 0,4. В составе подлеска доминирует душекия (30\%), также произрастают береза, кедровый стланик с покрытием 10-15\% и шиповник. Травяно-кустарничковый покров умеренно развит, проективное покрытие 40-50\%, произрастают голубика, брусника, багульник, из трав в небольшом количестве (5\%) лимнас, мытник, колокольчик и злаки. Мохово-лишайниковый покров разреженный, мхи занимают в среднем $30 \%$, лишайники $-40-50 \%$.

В исследованном районе выявлено 38 видов лишайников, представляющих 5 семейств, 11 родов. Наибольшее количество видов отмечено из семейств Cladoniaceae и Parmeliaceae (табл. 4.4). 
Та бл ица 4.4

Характеристика лишайниковых сообществ на учетных площадках

\begin{tabular}{|l|c|c|c|}
\hline \multicolumn{1}{|c|}{ Характеристика } & Зона 1 & Зона 2 & Зона 3 \\
\hline Общее количество лишайников & 32 & 20 & 26 \\
\hline Количество эпифитов & 13 & 9 & 12 \\
\hline Количество эпигейных видов & 17 & 10 & 14 \\
\hline Количество эпилитных видов & 2 & 1 & - \\
\hline Среднее проективное покрытие эпигейных видов, \% & 28 & 37 & 46 \\
\hline Среднее проективное покрытие у основания ствола, \% & 0,18 & 0,37 & 0,53 \\
\hline $\begin{array}{l}\text { Среднее проективное покрытие на высоте 1,3 м от осно- } \\
\text { вания ствола, \% }\end{array}$ & 0,14 & 0,14 & 0,17 \\
\hline
\end{tabular}

Наибольшее количество видов лишайников отмечается в сильно загрязненной зоне (зона 1), при переходе к незагрязненной (зона 3) число видов постепенно уменьшается, что можно объяснить возможным изменением $\mathrm{pH}$ среды от кислого до щелочной, потому что на лишайниковый покров кроме угольного разреза дополнительное отрицательное влияние оказывают сам город, автомобильный транспорт и железная дорога. Как отмечают некоторые авторы (Нильсон, Мартин, 1982), кислотность субстрата является одним из факторов, определяющих как прямое, так и косвенное влияние на жизнедеятельность лишайников. Влияние кислого загрязнения на лишайниковую флору в конечном итоге явно отрицательное, как показано большим количеством исследований. Но влияние щелочного загрязнения носит двоякий характер. С одной стороны, как при всяком загрязнении, наблюдается повреждающее действие щелочных веществ. С другой стороны, можно указать на некоторое положительное влияние щелочных веществ, особенно на фоне кислого загрязнения. Под влиянием щелочных загрязнителей наблюдается повышение $\mathrm{pH}$ как субстратов, так и самих лишайников. Повышение $\mathrm{pH}$ субстрата лишайников имеет косвенный удобрительный эффект даже в том случае, если в загрязнителе не содержится питательных веществ, необходимых для лишайников.

При переходе от сильно загрязненной зоны также увеличивается и среднее проективное покрытие эпигейных лишайников примерно в 1,5 раза. Причем у основания стволов среднее проективное покрытие увеличивается до 3-х раз, на высоте ствола 1,3 м - в 1,2 раза.

Уровни загрязнения атмосферы можно определить по индексам полеотолерантности, токсифобности, Нами по литературным источникам 
составлен сравнительный список видов лишайников для каждой зоны (табл. 4.5). Установлено, в районе исследований преобладают выносливые эпифитные лишайники.

Таблица 4.5

Относительная устойчивость некоторых эпифитов к уровню загрязнения атмосферы (по литературным данным)

\begin{tabular}{|c|c|c|c|c|c|c|c|c|c|c|c|c|}
\hline \multirow[t]{2}{*}{$\begin{array}{c}\text { № } \\
\Pi / \Pi\end{array}$} & \multirow[t]{2}{*}{ Виды } & \multicolumn{4}{|c|}{ Зоны } & 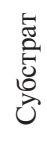 & \multicolumn{6}{|c|}{$\begin{array}{c}\text { Литературный источник } \\
\text { (индексы полеотолерантно- } \\
\text { сти }{ }^{1}, \text { токсифобности르, уровни } \\
\left.\text { загрязнения атмосферы }{ }^{3}\right)\end{array}$} \\
\hline & & 1 & 2 & 3 & 4 & $\mathrm{C}$ & $1^{3}$ & $2^{3}$ & $3^{1}$ & $4^{1}$ & $5^{2}$ & $6^{1}$ \\
\hline 1 & 2 & 3 & 4 & 5 & 6 & 7 & 8 & 9 & 10 & 11 & 12 & 13 \\
\hline 1 & Peltigera apthosa & + & + & + & + & $\Gamma$ & & & & & & \\
\hline 2 & Peltigera canina & + & + & + & + & $\Gamma$ & & & & & 10 & \\
\hline 3 & Cladonia rangiferina & + & + & + & + & $\Gamma$ & & & & & & \\
\hline 4 & Cetraria cucullata & + & + & + & + & $\Gamma$ & & & & & & \\
\hline 5 & Cetraria laevigata & + & + & + & + & $\Gamma$ & & & & & & \\
\hline 6 & Parmeliopsis hyperopta & + & + & + & + & $\Phi$ & 3 & & & 3 & $4,8,9$ & 1,2 \\
\hline 7 & Evernia mesomorpha & + & + & + & + & $\Phi$ & & 1,2 & $1-3$ & 5 & 10 & $1-6$ \\
\hline 8 & Parmelia sinuosa & + & + & + & + & $\Phi$ & & & & 1 & 10 & \\
\hline 9 & Hypogymnia physodes & + & + & + & + & $\Phi$ & 2,4 & 1,2 & $1-3$ & 6 & 8 & 4 \\
\hline 10 & Bryoria simplicolor & + & + & + & + & $\Phi$ & & & 2,3 & & & \\
\hline 11 & Bryoria implexa & + & + & + & + & $\Phi$ & & & 2,3 & 4 & 7 & \\
\hline 12 & Vulpicida pinastri & + & + & + & + & $\Phi$ & 3 & & 3 & & & 3 \\
\hline 13 & Cladonia stellaris & + & + & + & + & $\Gamma$ & & & & & & \\
\hline 14 & Cladonia amaurocraea & + & + & + & + & $\Gamma$ & & & & & & \\
\hline 15 & Cladonia gracilis & + & + & + & + & $\Gamma$ & & & & & & \\
\hline 16 & Stereocaulon paschale & + & + & & + & $\Gamma$ & & & & & & \\
\hline 17 & Hypogymnia bitteri & + & & + & + & $\Phi$ & & & & & 7 & 1 \\
\hline 18 & Cladonia deformis & + & & + & + & $\Gamma$ & & & & & & \\
\hline 19 & Cladonia uncialis & + & & + & + & $\Gamma$ & & & & & & \\
\hline 20 & Stereocaulon glareosum & + & & & + & $\Gamma$ & & & & & & \\
\hline 21 & Parmelia sulcata & + & & & + & $\Phi$ & $2-4$ & $1-5$ & $1-3$ & 5,7 & $1-9$ & 5,6 \\
\hline 22 & Cladonia phyllophora & + & & + & & $\Gamma$ & & & & & & \\
\hline
\end{tabular}


Окончание табл. 4.5

\begin{tabular}{|c|l|c|c|c|c|c|c|c|c|c|c|c|}
\hline 1 & \multicolumn{1}{|c|}{2} & 3 & 4 & 5 & 6 & 7 & 8 & 9 & 10 & 11 & 12 & 13 \\
\hline 23 & Parmelia olivaceae & + & & + & & $\Phi$ & & & & 5 & 2,6 & $1-5$ \\
\hline 24 & Stereocaulon wrigthii & + & + & & & $Л$ & & & & & & \\
\hline 25 & Parmelia omphalodes & + & + & & & $\Phi$ & & & & & 8,5 & 5 \\
\hline 26 & Parmelia centrifuga & + & & & & $\Phi$ & & & & & & \\
\hline 27 & Cladonia furcata & + & & & & $\Gamma$ & & & & & & \\
\hline 28 & Cladonia coccifera & + & & & & $\Gamma$ & & & & & & \\
\hline 29 & Nephroma arcticum & + & & & & $Л$ & & & & & & \\
\hline 30 & Cladonia arbuscula & + & & & & $\Gamma$ & & & & & & \\
\hline 31 & Cetraria seliaris & + & & & & $\Gamma$ & & & & & & \\
\hline 32 & Evernia esorediosa & + & & & & $\Phi$ & & & $1-3$ & & & $1-6$ \\
\hline 33 & Parmeliopsis ambigua & & + & + & + & $\Phi$ & 3 & 1,2 & & 4,5 & $1-9$ & 2,3 \\
\hline 34 & Cladonia chlorophaea & & + & & + & $\Gamma$ & 4 & & $1-3$ & & & \\
\hline 35 & Cladonia bacillaris & & & + & & $\Gamma$ & & & & & & \\
\hline 36 & Cladonia mitis & & & & + & $\Gamma$ & & & & & & \\
\hline 37 & Evernia divaricata & & & & + & $\Phi$ & & & $1-3$ & 2 & 9 & 1,2 \\
\hline 38 & Alectoria ochrolenuca & & & & + & $\Phi$ & & & & & & \\
\hline
\end{tabular}

Примечания: Субстрат произрастания, обозначения: Г - эпигейный вид, Ф эпифит, Л - эпилит. Литературный источник: 1 - Журавлева, 2005, 2 - Меркулова, 2006, 3 - Баумгертнер, 1999, 4 - Трасс, 1985, 5 - Инсарова, Инсаров, 1989, 6 - Рыкова, 2004.

\section{Изменение биохимического состава лишайников}

Воздействие открытой добычи угля на растительность можно дополнить и изменением биохимического состава лишайников.

В любом живом организме постоянно протекают реакции окисления субстрата, являясь факторами регуляции важнейших метаболических процессов. Постоянство уровня суммарной антиокислительной активности тканей и индивидуальность этого уровня для каждого организма служат одним из основных показателей гомеостаза. При негативном для организма влиянии окружающей среды, изменении определенных факторов происходит ответная защитная реакция на раздражитель. В первую очередь резко активизируются процессы антиоксидантной защиты от свободнорадикального окисления субстратов (Журавлева, 2005). 
Биологический механизм биоантиокислителей сводится к смещению конкурентного отношения свободнорадикального и ферментативного окисления в пользу ферментативного, тем самым биоантиокислители регулируют степень подавляющего влияния свободнорадикального окисления на большинство метаболических процессов. Конечным итогом действия биоантиокислителей является создание оптимальных условий для метаболизма и обеспечение нормального роста клеток и тканей (Баумгертнер, 1999). В любом живом организме постоянно протекают реакции окисления субстрата, являясь факторами регуляции важнейших метаболических процессов. Постоянство уровня суммарной антиокислительной активности тканей и индивидуальность этого уровня для каждого организма служат одним из основных показателей гомеостаза.

В экстремальных неблагоприятных условиях окислительные процессы в клетке активируются, расход антиоксидантов увеличивается и, когда концентрация последнего падает ниже критической, окисление липидов резко возрастает. Окисление липидов приводит к разрушению комплекса белок-липид, патологии мембран и гибели клетки (Инсарова, Инсаров, 1989). Для преодоления этого воздействия организмы выработали комплексную, многоступенчатую превентивную систему, состоящую из многочисленных ферментов, таких как супероксиддисмутаза (СОД), каталаза, глутатион пероксидаза и др., а также из низкомолекулярных антиоксидантов (НМАО).

В качестве объекта исследования нами выбраны широко распространенные на территории Якутии лишайники Cladina stellaris и Cetraria laevigata (Соловьева, Кудинова, 2007). Отбор проб проводился в конце июля и в начале августа. В качестве контроля выбрана зона 3.

Активность антиоксидантных систем $\left(k_{\text {аоз }}\right)$ лишайников и коэффициент антиоксидантно-прооксидантного равновесия $\left(k_{\text {аоз }} / k_{\text {пол }}\right)$ рассчитывали по формулам:

$\left(k_{\text {аоз }}\right)_{\mathrm{N}}=\mathrm{S}$ (параметры АО-систем $)_{N} /$ кол-во изученных АО-систем, где (параметры АО-систем) ${ }_{\mathrm{N}}-$ нормированные к контролю значения НМАО, СОД;

$$
\left(k_{\text {аоз }} / k_{\text {пол }}\right)_{N}=\left(k_{\text {аоз }}\right)_{N} / \text { [активность ПОЛ] }{ }_{N},
$$

где активность ПОЛ ${ }_{\mathrm{N}}-$ нормированное к контролю содержание МДА.

Суммарное содержание НМАО и фермента СОД, у обеих видов лишайников увеличивается с переходом от более загрязненной зоны (зона 1) к менее загрязненной зоне (зона 3), при этом по отношению к контрольной зоне содержание НМАО повышено, а активность СОД понижена. 
Процессы перекисного окисления липидов у двух видов лишайников почти в 3 раза интенсивнее протекают в зоне 1 , по сравнению с фоновой зоной (рис. 4.1, а и б). При этом у вида Cetraria laevigata при переходе в зоны 2 и 3 процессы ПОЛ менее выражены, что объясняется высокой активностью защитных систем в слоевище лишайника.

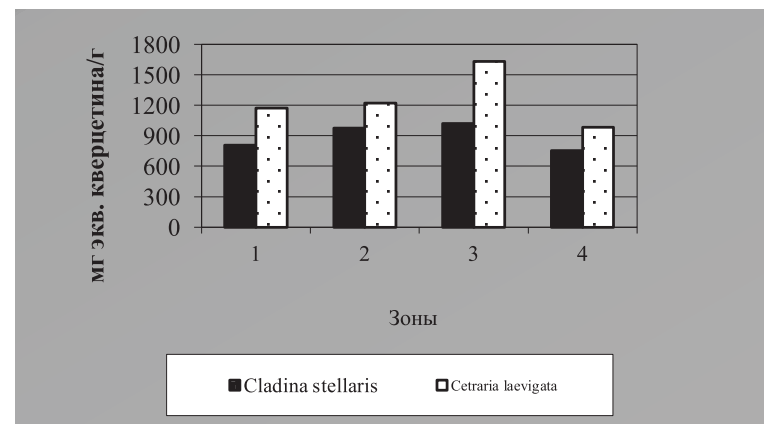

Рис. 4.1, а. Суммарное содержание НМАО

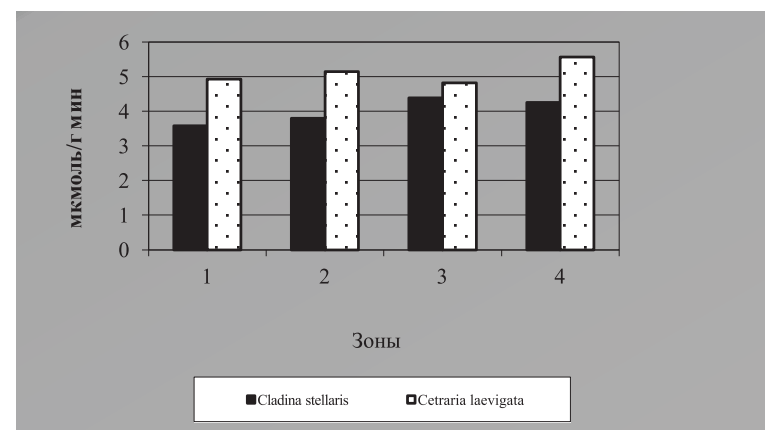

Рис. 4.1, б. Активность фермента в лишайниках мг экв. кверцетина/г СОД мкмоль/г мин

В загрязненной зоне 1, при наибольшей пылевой нагрузке, происходит истощение антиоксидантной системы лишайников, вследствие этого резко возросло окисление липидов, которое со временем приводит к разрушению комплекса белок-липид, патологии мембран и гибели клетки. Наиболее резко защитные механизмы активизированы в зоне 3 , где отмечается сравнительно наибольшее содержание антиоксидантов в лишайниках (табл. 4.6). 
Таблица 4.6

Показатели антиоксидантной защиты лишайников по отношению к контролю

\begin{tabular}{|l|l|c|c|c|c|c|}
\hline Вид лишайника & $\begin{array}{c}\text { Зоны техноген- } \\
\text { ной нагрузки }\end{array}$ & $\sum$ НМАО & $\begin{array}{c}\text { Актив- } \\
\text { ность СОД }\end{array}$ & ПОЛ & $\boldsymbol{k}_{\text {аоз }}$ & $\boldsymbol{k}_{\text {аозппл }}$ \\
\hline Cladonia stellaris & 1 & 1,07 & 0,84 & 2,96 & 0,96 & 0,32 \\
\cline { 2 - 7 } & 2 & 1,29 & 0,89 & 2,18 & 1,09 & 0,5 \\
\cline { 2 - 7 } & 3 & 1,35 & 1,03 & 1,62 & 1,19 & 0,73 \\
\cline { 2 - 7 } & 4 контроль & 1 & 1 & 1 & 1 & 1 \\
\hline Cetraria laevigata & 1 & 1,19 & 0,89 & 2,73 & 1,04 & 0,38 \\
\cline { 2 - 8 } & 2 & 1,24 & 0,92 & 1,06 & 1,08 & 1,02 \\
\cline { 2 - 8 } & 3 & 1,66 & 0,87 & 1,08 & 1,27 & 1,18 \\
\cline { 2 - 8 } & 4 контроль & 1 & 1 & 1 & 1 & 1 \\
\hline
\end{tabular}

В лишайниках Cladina stellaris и Cetraria laevigata коэффициент антиоксидантной защиты и коэффициент антиоксидантно-прооксидантного равновесия смещен в сторону усиления защитных реакций при переходе от зоны 1 к зоне 3 . Как видно из показателей $k_{\text {аоз }} / k_{\text {пол }}$ равновесие систем сильно нарушено и смешено в сторону ПОЛ у вида Cladina stellaris. Вид Cetraria laevigata оказался наиболее устойчивым к неблагоприятным факторам окружающей среды, коэффициент равновесия смещен в сторону усиления антиоксидантной защиты.

Таким образом выявлено, что лишайники вида Cladina stellaris, более чувствительны к изменениям в окружающей среде, чем лишайники вида Cetraria laevigata. Интенсивность процессов перекисного окисления липидов и уровни содержания антиоксидантов показывают степень угнетения, ответ организма на неблагоприятные воздействия окружающей среды. Конечным результатом описанных выше процессов является угнетение таких важных процессов жизнедеятельности как рост и развитие организма талломов лишайников в результате патологии и гибели клеток. 


\section{Гдава 5. ОПТИМИЗАЦИЯ ТЕХНОГЕННОЙ РАСТИТЕ ЯЬНОСТИ}

Познание специфики процесса формирования растительного покрова на нарушенных землях представляет существенный интерес для планирования и осуществления конкретных фитомелиоративных и природоохранных мероприятий. В этом аспекте, изучение естественного зарастания промышленных отвалов позволяет оценить фитопригодность отвальных грунтов, скорость их зарастания, направление сукцессионных смен и по этим критериям выявить степень необходимости вмешательства человека в ход восстановительного процесса.

Самовосстановление техногенных земель начинается с «нуля», при практическом отсутствии всех живых компонентов биоты. Их заселение живыми организмами происходит спонтанно. Процесс этот длительный, его направление и скорость зависит от многих факторов, поэтому в большинстве случаях существует необходимость в искусственном восстановлении растительного покрова или рекультивации. Конечной целью комплекса работ по рекультивации является создание местообитаний, обеспечивающих восстановление биологической продуктивности и выполнение других экологических функций (Кандрашин и др., 1992).

Рекультивация должна проводиться обязательно в 2 этапа - технического и биологического. Техническая рекультивация проводится предприятиями горного производства. Задачей биологической рекультивации является создание устойчивых, с высокой продуктивностью, с активными средопреобразующими качествами растительных сообществ.

Приемы и методы биологической рекультивации давно разрабатываются в промышленно развитых странах и в том числе регионах России (Моторина, 1975; Рекультивация земель...,1973; Баранник, 1978; Колесников, Моторина, 1979; Горлов, 1981; Экологические аспекты..., 1984; Переверзев, Подлесная, 1986; Поляков и др., 1987; Творогов, Неустроева, 1987; Кандрашин и др., 1992, Куприянов и др., 2010; Миронова, 2016 и др.), проводятся опытно-экспериментальные работы по рекультивации. Как показывают исследования, к выбору оптимального направления рекультивации в силу значительной сложности осуществления последней необходимо подходить в каждом случае строго индивидуально и учитывать весь комплекс факторов. Общие положения закреплены в действуюшем в нашей стране с 1984 г. ГОСТе «Охрана природы, земли. Общие требования к рекультивации земель». 
Значительным вкладом в разработку и унификацию методов исследования биоценотических процессов в техногенных ландшафтах стала монография «Программа и методика изучения техногенных биогеоценозов» (Колесников, Моторина, 1978), где отмечено, что «при изучении растительного покрова «техногенных неокомплексов» используются известные методы геоботаники и биогеоценологии и экспериментальной ботаники. Отправными моментами являются изучение видового состава и структуры фитоценозов, возникших на промышленных отвалах, что имеет очевидное значение для обоснования прикладных вопросов рекультивации».

Системный подход к изучению «регенерационных биогеоценозов» был предложен С.С. Трофимовым, А.А. Титляновой и И.Л. Клевенской (1979).

Всестороннее изучение процессов почвообразования и основных аспектов рекультивации на территории Кузбасса и Сибири проведены сибирскими учеными. Многолетние исследования показали: несмотря на то, что строение, свойства и режимы формируюшегося почвенного покрова чаще всего лишь в некоторой степени соответствуют характеристикам естественно-исторических образований, тем не менее, они также выполняют определенные экологические и геохимические функции (Экология и рекультивация..., 1992; Андроханов и др., 2004).

Изучение растительности проводилось на различных уровнях:

a) местообитания (парцеллы);

б) рельефа;

в) ландшафта (Куприянов, 1989; Капелькина, 1993; Куприянов, Манаков, 1995; Манаков, Скобликов, 1996; Манаков и др., 2011 и др.).

Методам изучения сукцессий посвящена фундаментальная сводка В.Д. Александровой (1964), где все методы изучения динамики растительности подразделены на прямые (наблюдение на постоянных площадках) и косвенные (экстраполяция пространственных рядов во временные). Последний метод представляет большое удобство для изучения динамики растительного покрова отвалов, где можно точно определить возраст отсыпки (Миронова, 2000).

Наиболее обстоятельным методическим руководством для изучения процессов нарушений и смен растительного покрова является коллективная монография научного коллектива Ботанического института им. Комарова (Антропогенная динамика..., 1995), изданная под редакцией Б.А. Юрцева.

Технология биологической рекультивации до сих пор не разработана на Севере. В настоящее время проблема рекультивации, особенно биологической, остро встает в суровых условиях Якутии, где затруднено спонтанное формирование сомкнутого растительного покрова. 
На территории Якутии нарушенные техникой земли до сих пор оставались без каких-либо восстановительных работ, и только с 1987 года промышленным предприятиям предъявляется требование проведения технической рекультивации после отработки месторождений. Проблемы биологической рекультивации до сих пор находятся на начальной стадии изучения. При этом самозарастание техногенно нарушенных местообитаний идет крайне медленно, и это оказывает негативное влияние на урбанизированные территории, расположенные вблизи отвалов. Полное (или относительно полное) восстановление растительности требует сотни лет.

В Якутии проводятся кратковременные опыты по биологической рекультивации. На пример, в Южной Якутии на дражных отвалах (Кузьмин, 1985; Гончаров, 1987; Петрова, 1994) и на отвалах пустых пород карьера «Мир» (Лебедева, Лонкунова, 1990). Учеными практически доказана возможность создания на отработанных дражных полигонах пахотных угодий в условиях криолитозоны для возделывания овощных культур, а также кормовых одно- и многолетних трав только при экранировании поверхности отвала слоем почвы (Проблемы техногенеза..., 1987).

Сотрудниками лаборатории охраны природы института ЯкутНИИПРОАЛМАЗ был проведен ряд опытов для выявления возможности рекультивации отвалов, как в санитарно-гигиенических целях, так и в сельскохозяйственных - для выращивания многолетних кормовых трав (Лебедева, Лонкунова, 1990). На отвале вскрышных и вмещающих пород карьера «Водораздельные галечники» были заложены опытные участки с использованием 7 видов многолетних злаков (пырейник сибирский, пырейник изменчивый, пырейник волокнистый, бекмания восточная, пырей ползучий, кострец безостый и кострец Караваева). Было испытано 37 образцов различных сортов и дикорастущих популяций. В результате трехлетних наблюдений выявлено, что наименее устойчивым в наших условиях оказался кострец Караваева, наиболее - пырейники волокнистый, изменчивый и сибирский, а также кострец безостый. Проведенные опыты также показали, что нанесение на поверхность отвалов слоя глины и суглинка мощностью 20 см с последующим посевом наиболее устойчивых видов многолетних трав позволяет создать устойчивый растительный покров.

На аласных экосистемах в бассейне р. Вилюй сотрудниками Института северного луговодства АН РС (Я) разработаны способы, нормы и сроки посева многолетних трав (Денисов, 1983; Денисов и др., 1989).

Проведение биологической рекультивации требует восстановления плодородного слоя почвы и полного разравнивания поверхности, 
что связано с неоправданно высокими затратами. К этому добавляются трудности с приобретением семян, удобрений и их дороговизна.

Применение удобрений на сенокосах и пастбищах, а также на улучшенных участках Якутии не ново. Удобрения применялись на пойменных, мелкодолинных и аласных лугах (Петров, 1962; Рекомендации ..., 1973; Якушев, 1975; Денисов, 1976, 1984; Кононов и др.,1979; Нахабцева, 1979, 1981). Также они применялись и при биологической рекультивации техногенно нарушенных территорий (Петрова, 1994). Тем не менее, среди этих исследований нет работ по применению удобрений при самозарастании промышленных земель.

При добыче полезных ископаемых селективная отсыпка и рыхлые осадочные породы оказываются под пустыми крупнообломочными породами, что лишает возможности их использования при биологической рекультивации. В связи с этим остро стоит вопрос выработки приемов ускорения самовосстановительной сукцессии и способов ее управления для достижения значительной экономии средств.

\section{1. Биодогическая рекудьтивация на отвалах угодьных месторождений}

В Советском Союзе основными центрами угольной промышленности были Донбасс и позже Кузбасс. Первые рекультивационные работы проводились на Донбассе в 1970-х годах (Рекультивация земель..., 1973).

В настоящее время самые крупные месторождения угля в России находятся в Кузбассе и Южной Якутии - в Нерюнгринском районе.

Кузнецкий бассейн является крупнейшим в России, как по запасам угля, так и по добыче (Куприянов и др., 2010). Здесь ежегодно добывается $76 \%$ коксующихся марок угля в России. Доля Кузбасса в общероссийском экспорте составляет $80 \%$.

Добыча угля сопровождается огромным экологическим ущербом природным экосистемам. Специалистами Института угля и геохимии СО РАН установлено, что на 1 млн т добытого угля приходится 36 га уничтоженного слоя плодородной земли (Счастливцев, 2003). Оценка почвенно-экологической эффективности в Кузбассе показала, что $70 \%$ поверхности отвалов представляют собой техногенную пустыню и только $2 \%$ нарушенных территорий обладают хорошими почвенно-экологическими условиями, которые могут поддержать восстановительную сукцессию (Андроханов и др., 2004). Это означает, что $98 \%$ территории нуждается в проведении рекультивационных мероприятий.

Добыча угля также сопровождается разрушением природных экосистем и заменой их на антропогенно (техногенно) измененные формы 
(Куприянов и др., 2010). Техногенные ландшафты коренным образом отличаются от природных ландшафтов по эдафическим, экологическим, биологическим, биохимическим и другим показателям.

Полная реставрация ландшафта достигается только в тех случаях, когда функциональные и структурные показатели производных экосистем будут соответствовать уровню естественных зональных. Идеальным вариантом является реставрация нарушенного ландшафта, т.е. восстановление рельефа, почвы вместе с плодородным слоем, растительного покрова по типу прежде существовавшего природного ландшафта той или иной местности (Bradshow, 1996).

Большие успехи по рекультивации угольных отвалов достигнуты в Кузбассе. В начале 1970-х годов восстановлением экосистем на отвалах Кузбасса заинтересовались выдающиеся ученые как В.В. Тарчевский - основоположник промышленной ботаники в России, почвовед С.С. Трофимов, лесоведы Г.В. Крылов и Л.П. Баранник (Куприянов, 2009). Их теоретические и практические результаты стали основой рекультивационных работ в регионе.

Биологическая рекультивация включает комплекс фитомелиоративных и агротехнических мероприятий, направленных на возобновление среды обитания растений, животных и других компонентов биоты. В различных методических рекомендациях пишется в основном о землях сельскохозяйственных угодий и лесного фонда.

О рекультивации в условиях распространения многолетнемерзлых пород говорится мало, здесь рекультивационные работы находятся на стадии опытных исследований. Рекультивация мелкого масштаба проводилась в землях после добычи россыпных месторождений золота в аллювиальных отложениях Северо-Востока России, вдоль трассы трубопроводов в Западной Сибири, в республике Коми, на Кольском Севере, а также на Таймыре.

На нарушенных землях Курской магнитной аномалии (KMA) и Донбасса учеными установлены закономерности изменения экологических и лесорастительных условий, проведена их классификация, определены были технология выполнения работ, выбор ассортимента трав и древесно-кустарниковых пород и агротехника их выращивания, использование мелиоративных средств улучшения среды обитания, проектирование комплексных мероприятий по восстановлению земель (Лесная рекультивация..., 1991).

В Кузбассе рекультивация нарушенных земель получила развитие в 1980-х годах на отвалах угольных месторождений (Биологическая рекультивация..., 1981; Техногенные экосистемы, 1985; Баранник, 1988; и др.). И в настоящее время проблема нарушенных земель для Кемеровской 
области чрезвычайно актуальна. Исследователями установлено, что промышленная зона Кузбасса давно уже находится в состоянии экологического бедствия, т.к. вынос на поверхность громадной массы - свыше 12 млрд кубометров - глубинных пород привёл к изменению рельефа: образовались техногенные горно-породные отвалы, карьерные выемки и депрессионные воронки, понизился уровень грунтовых вод. По данным государственного доклада «О состоянии окружающей природной среды Кемеровской области в 2002 году», на начало 2003 года в регионе насчитывалось почти 65 тыс. гектаров земель, подлежащих рекультивации. По прогнозам специалистов Института угля и углехимии СО РАН до 2010 года их площадь увеличится еще на 23 тыс. га. Из них рекультивировано с 1990 года 10,5 тыс. га. Самая большая доля нарушенных земель приходится на «Кузбассразрезуголь» - около 30 тыс. га.

Научные коллективы Сибири более 40 лет работают над проблемой восстановления нарушенных земель (Биологическая рекультивация...,1981; Баранник, 1988; Ламанова, 2002, Куприянов и др., 2010 и др.). Учеными доказано, что действующие методические указания по рекультивации земель, нарушенных при открытом способе добычи угля, разработаны ГОСТом 1986 года для всей территории бывшего Советского Союза без учета региональных особенностей. Их практически невозможно осуществить: они предполагают планировку поверхности - восстановление почв, сложенных в определенном порядке. Сначала 60 см водоупорного слоя - глины или суглинка; потом до 1-2 метров - на глубину проникновения корневой системы - плодородный слой: Но чтобы нанести один метр почвы и восстановить один гектар, надо «оскальпировать» 5 га земли. Такое практически невозможно осуществить.

В Якутии отработанные горнодобывающими предприятиями земли в большинстве случаев оставлялись без рекультивации на «самоизлечение», подвергаясь опасным криогенным процессам и явлениям (солифлюкции, термоэрозии, термокарсту и др.), значительно расширяющих зону нарушений и способствующих вторичному загрязнению наземных и водных экосистем. В этой связи актуальны и обязательны рекультивационные работы.

В 1990-х годах на дражных отвалах Южной Якутии и на угольном разрезе «Кангаласский» (окрестности г. Якутска) сотрудниками Института биологии СО РАН проводилась биологическая рекультивация с посевом многолетних злаков (мятлик луговой, овсяница красная, житняк гребенчатый, кострец безостый, ломкоколосник ситниковый, пырей ползучий, ячмень короткоостистый), которая показала широкие возможности использования перспективных многолетних дернообразующих трав для рекультивации (Петрова, 1994). 


\section{С.И. Миронова, В.В. Иванов}

Сотрудники Института прикладной экологии Севера с 1993-го года работают над решением проблемы восстановления (биологической рекультивации) нарушенных техногенных земель. Первые годы целью исследований была изучение процесса ускорения самозарастания отвалов на месторождениях золота по долине р. Селигдар (приток р. Алдан) путем внесения минеральных удобрений. Опыты показали эффективность метода на молодых отвалах (5-15 лет). Внесение удобрений заметно ускоряет процесс самозарастания и стимулирует раннему появлению древесно-кустарниковых растений на дражных отвалах. По результатам исследований разработаны научно-практические «Рекомендации по отводу под самозарастание земель, нарушенных горными работами» (2001).

На втором этапе работы (2001-2003 гг.) по биологической рекультивации проводились на отвалах вскрышных пород месторождения «Биллях» в бассейне р. Анабар. Методы посева многолетних трав (бекманнии восточной) показали высокие результаты, когда всходы второго года имели проективное покрытие до $60 \%$, а урожайность достигла до 1 кг с кв. м. Результаты обсуждались на республиканской научно-практической конференции «Экологическая безопасность при разработке россыпных месторождений алмазов» (Якутск, 2004).

Третий этап работ включает опытные работы на отвалах карьера «Мир» (2003-2004 гг). На отвале № 6 карьера высотой 60 м и крутизной откоса до $45 \%$ путем покрытия скальных пород вскрышными из отвалов Водораздельного галечника и посева семян диких трав получили задернение поверхности с проективным покрытием травостоя 15-40\%. С каждым годом видовой состав и проективное покрытие увеличивается с доминирование полыни и осота, чертополоха. Есть надежда, что на данном отвале почвенно-растительный покров закрепится, тогда и пессимисты поймут, что такое возможно.

С 2005 года опытные работы начались на отвалах разреза «Нерюнгринский». О возможности самозарастания на отвалах угольных месторождений споров нет, но данный процесс в условиях Якутии замедляется и его нужно ускорить искусственным путем.

Комплексные экологические исследования Южной Якутии показали изменение природной среды, техногенную трансформацию элементов экосистемы до образования природно-техногенных и техногенных экосистем (Миронова, 2000; Природно-техногенные..., 2006). Авторы отмечают, что широкое распространение на территории имеют природно-техногенные и техногенные ландшафты на дражных полигонах и отработанных рудных месторождениях. Самыми распространенными типами техногенного рельефа являются:

- холмисто-седловинные отвалы пустых пород; 
- котловинные формы хвостохранилищ обогатительных фабрик;

- промышленные площадки;

В настоящее время хозяйственная деятельность вызвала глобальные изменения в биосфере, в том числе жестко отразились на растительности - единственном источнике кислорода и основном продуценте органического вешества, которое питает бесхлорофильные организмы планеты, включая человека.

Природно-климатические условия Нерюнгринского района в отличие от природы Кузбасса имеют свои особенности:

- климат района резко континентальный с отрицательной среднегодовой температурой воздуха $\left(-9,5^{\circ} \mathrm{C}\right)$;

- среднегодовое количество осадков составляет 496 мм; устойчивый снежный покров держится 210 дней;

- характерны устойчивые температурные инверсии в приземном слое, сопровождающиеся появлением туманов и скоплением вредных веществ - пыли и газа;

- повсеместное распространение многолетнемерзлых пород (на 70$80 \%$ площади и глубину от 2 до 100 м).

Нерюнгринское месторождение коксующихся углей представляет собой замкнутую брахисинклинальную складку, вытянутую с северо-запада на юго-восток, с углами падения крыльев на выходах пласта 10-30 и с почти плоским днищем. Длина складки 6 км, ширина - 3,9 км.

Породы вскрыши представлены преимущественно (на 80-85\%) кварц-полево-шпатовыми песчаниками: крупно-, средне-, мелкозернистыми; значительно реже встречаются аргиллиты, алевролиты и гравелиты. Цемент песчаников по составу разнообразный: гидрослюдистый, железисто-гидрослюдистый, глинисто-гидрослюдистый, карбонатный и другие. Химические анализы показали не токсичность пород, следовательно, рекультивационные работы могут проводиться на техногенных грунтах без нанесения плодородного слоя.

\section{2. Опыты по биодогической рекудьтивации на отвалах разреза «Нерюнгринский»}

Для проведения опытно-экспериментальных работ по биологической рекультивации на отвалах разреза «Нерюнгринский» нами сначала были изучен рекультивационный потенциал нарушенных участков разреза (Миронова, 2000; Миронова и др., 2007, 2009, 2012, 2015), а затем в 2005 году были заложены опытные участки.

Перед нами была поставлена цель - ускорение процессов восстановления и выявление вариантов и способов биологической рекультивации 
с применением семян и саженцев видов местной флоры, а также семян интродуцированных для Якутии культур многолетних растений.

В результате рекогносцировочных исследований отработанных Западных отвалов был выбран опытный отвал № 25 (рис. 5.1), который отличается от других:

- полной отработанностью отвала;

- доступностью для прохождения транспорта;

- близостью посадочного материала - естественных лесных и кустарниковых сообществ.

\section{Схема опыта}

Опытный участок площадью 4.45 га отработан в 1991 году и отсыпан над руслом р. Холодникан (рис. 5.2).

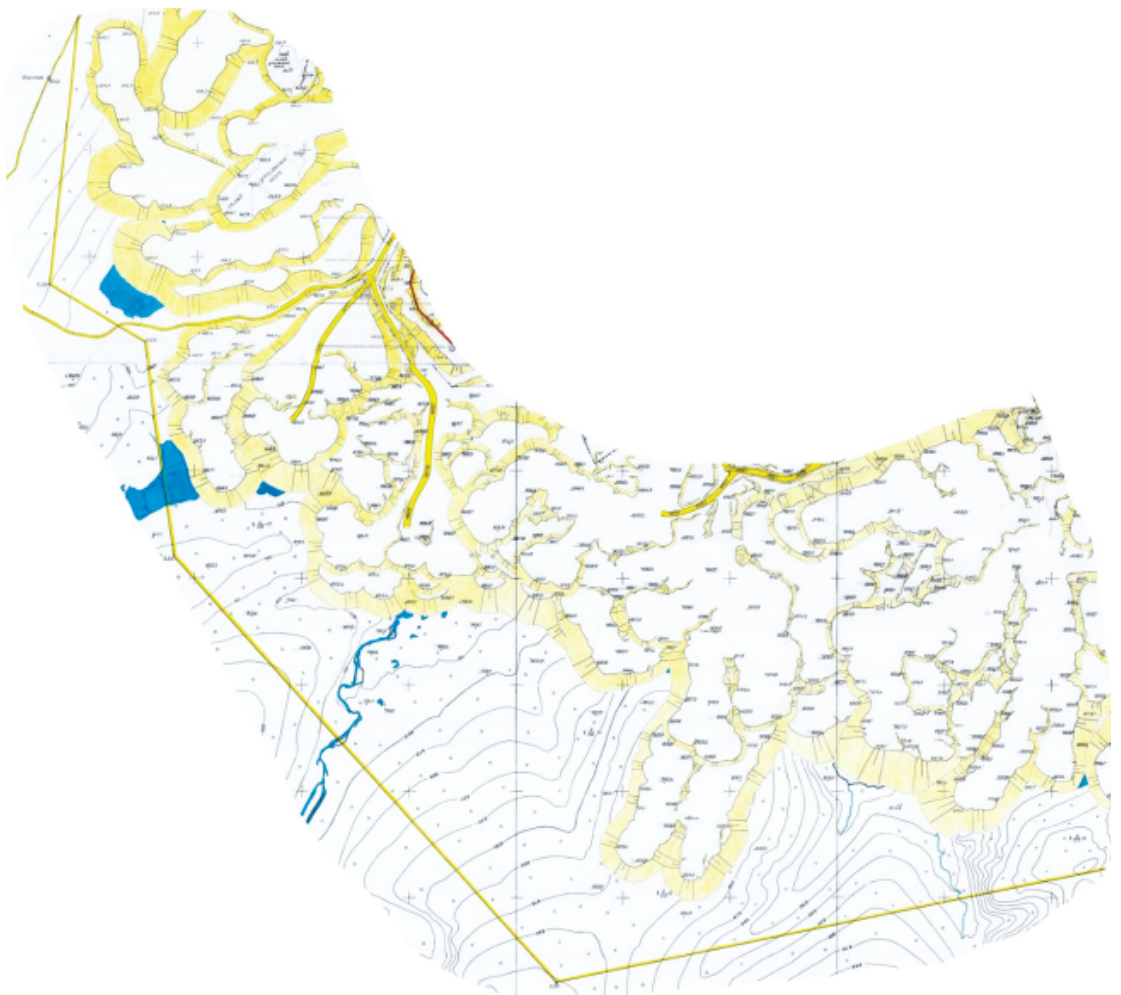

Рис. 5.1. Схема Западных отвалов Нерюнгринского угольного разреза 


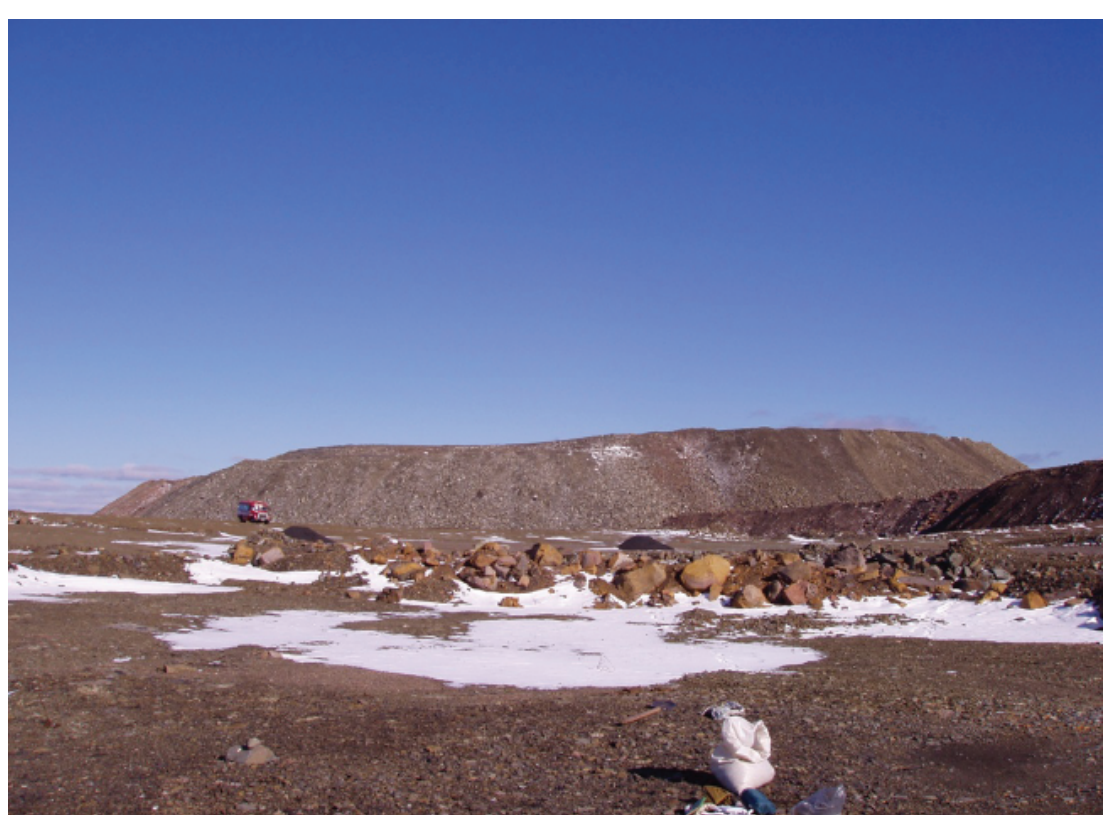

Рис. 5.2. Общий вид опытного участка (2005 г.)

На участке сотрудниками Института прикладной экологии Севера в 2005-2006 годах проводились комплексные экологические исследования с целью оценки его современного состояния.

Изучение техногенной поверхности, почвогрунтов и процесса зарастания отвалов позволили оценить пригодность техногенных отвалов для рекультивации, подобрать для этого древесно-кустарниковых пород и травянистых растений и определить подходящие агротехнические и агробиологические мероприятия.

\section{Характеристика поверхности}

Площадь опытного участка составляет 4,45 га. Отвал одноярусный, высокий (60-70 м) с крутыми откосами (более $30^{\circ}$ ).

Поверхность отвала плотно выровнена бульдозером, что препятствует росту растений. По краям местами оставлены небольшие отдельные кучи пород.

По проекту вскрышные породы на Нерюнгринском разрезе пред-

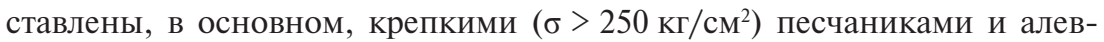
ролитами. Прочность таких пород в отвалах определяется, в основном, 
углом внутреннего трения, значение которого изменяется в пределах $33-37^{\circ} \mathrm{C}$. Допустимая высота устойчивого яруса отвала на прочном основании составляет более 200 м. Среди четвертичных отложений на месторождении выделяются аллювиальные, делювиальные и элювиальные породы. Делювиально-элювиальные образования представлены щебнистыми обломками песчаников и алевролитов с примесью супеси и песка мощностью от 0,5-1,5 м - на водоразделах и до 5 м - у подножия склонов.

\section{Состояние грунтов отвала}

По результатам почвенных исследований, проведенных институтом почвоведения и агрохимии, преобладающие в районе месторождения почвы подзолистого и болотного типа имеют невысокое плодородие, для возделывания сельскохозяйственных культур практически непригодны и в соответствии с ГОСТ 17.5.3.05-84 «Охрана природы. Рекультивация земель. Общие требования к землеванию» и ГОСТ 17.4.3.02-85 (СТ СЭВ 4471-84) «Охрана природы. Почвы. Требования к охране плодородного слоя почвы при производстве земляных работ» селективному снятию не подлежат. Песчаные грунты в результате процесса выветривания превращаются в песчано-щебнистый субстрат, бедный питательными веществами и обладающий плохими водоудерживающими свойствами.

По геохимическим данным ГГГП «Южякутгеология» по составу компонентов водных вытяжек и сумм токсичных воднорастворимых солей, обязанных происхождением собственно породам вскрыши, отвальные грунты не токсичны.

По исследованиям сотрудников Института прикладной экологии Севера (ИПЭС) грунты отвалов разреза сильно каменисты, по гранулометрическому составу песчаные, не засоленные, нейтральные или слабощелочные, с удовлетворительной емкостью поглощения, относительно обеспечены обменным калием, содержат мало подвижного фосфора. По приведенным характеристикам грунты пригодны для произрастания лесных культур.

Таким образом, породы отвала можно отнести к группе грунтов, пригодных для биологической рекультивации не сельскохозяйственного направления. Для создания благоприятных условий для роста и развития растений необходимо внести минеральные удобрения.

\section{Условия зарастания отвала}

Растительность на отвале находится на начальной стадии развития. На поверхности отвала, особенно с северной стороны, начинают появляться единичные подросты лиственницы, березы, кедрового стланика. Высота их не большая (от 10 см до 1 м). Единичные экземпляры 
чозении, тополя и сосны достигают высоты до 2-х м. На микропонижениях количество чозении составляет 8 штук на площадке $10 \times 10$ м. Травянистая растительность также находится на стадии развития, нет устойчивых сообществ, растут единичные экземпляры овсяницы, бескильницы, одуванчика, мари, иван-чая, полыни и бобовых. Общее проективное покрытие в микрогруппировках составляет 5-15\%, большая часть участка лишена растительного покрова.

На откосах отвала растений нет, лишь на более пологих склонах восточной экспозиции заметны единичные виды подроста кустарников и деревьев (лиственница, малина, тополь).

Рекультивация нарушенных земель при природоохранном, санитарно-гигиеническом и лесохозяйственном направлениях включает следующие агротехнические приемы (ГОСТ 17.5.3.04-83):

1. Подбор ассортиментов устойчивых растений.

2. Определение нормы высева семян и густоты посадки саженцев.

3. Определение сроков высева (посадки).

4. Подготовка грунтов и субстрата к посеву.

5. Уход за посевами и посадками.

Эти приемы конкретизуются в зависимости от природных условий.

Действующие методические указания по рекультивации земель, нарушенных при открытой добыче угля, разработаны для всей территории бывшего Советского Союза без учета региональных особенностей (ГОСТ 1986). Следовательно рекомендации по рекультивации нарушенных земель должны быть научно обоснованы для каждого региона огромной России отдельно.

Основной задачей опытных работ была ускорение процессов самозарастания отвала путем посева и посадок однолетних и многолетних растений. Результатами опытных рекультивационных работ будут:

- внедрение результатов опыта в производство;

- оздоровление санитарной и экологической обстановки в зоне влияние угольного разреза и города Нерюнгри;

- возвращение техногенные земли в хозяйственный оборот.

Осенью (сентябрь) 2005 г. на опытном отвале были заложены 12 опытных участков в 3-х вариантах каждый. Участки различались по составу почвогрунта и экспозиции откосов:

Участок 1 - опыты на грунтах с мелкоземом на поверхности отвала.

Участок 2 - опыты на грунтах с каменистыми породами на поверхности отвала.

Участок 3 - откосы отвала северной экспозиции.

Участок 4 - откосы отвала восточной экспозиции. 
На всех участках работа проводилась в 3-х вариантах опыта:

1. - а - контроль;

2. - б - внесение углесодержащих пород;

3. - в. - внесение минеральных удобрений;

Вся работа выполнялась вручную.

Методами посева семян растений являются естественный, искусственный и комбинированный. Искусственный включает выбор видов растений, нормы посева. Для посева в наличии имелись семена пырейника в норме 20 ц/га и смесь семян травянистых растений. Семена из 37 диких видов растений (однолетних и многолетних, сорных, кормовых и декоративных) были собраны на аласах Мегино-Кангаласского улуса и в долине Туймаада (г. Якутск). Агротехника посева состояла из ручной подготовки узких борозд гвоздями или палками, посева семян с засыпкой поверхности грунтом (вариант 1 - контроль), с внесением удобрений (вариант 2) и внесением углесодержащего грунта (вариант 3).

Посев пырейника и травосмесей на поверхности отвала производился рядами длиной 1 м и междурядьями - 0,5 м. На откосах посев произведен на террасках с рядами до 1-2 м и междурядьями 1-2 м.

Установлено, что по режиму увлажнения поверхность и крутые откосы отвала относятся к сухим и малопригодным для роста и развития растений. Откосы южных и западных экспозиций и вершины отличаются высокими летними температурами и зимним вымерзанием поверхности, а северные и восточные откосы имеют более благоприятные условия для роста растений.

\section{Результаты опытов}

Осенью (конец сентября) 2005 года нами были заложены первые деляны для посева семян пырейника. Так как посевы были позднеосенние, всходы пырейника начали появляться только осенью 2006 года (рис. 5.3). Больше проективного покрытия заметно по откосам отвала, а на поверхности темпы роста и развития растений не высоки. Причиной недружных всходов может быть и низкий процент всхожести семян, приобретенных в ОПХ «Покровское».

Всходы во всех вариантах опыта были почти одинаковы, но болееменее успешны посевы на участках с удобрениями, чем на контроле и участках с углесодержащими грунтами. Внесение удобрений на откосах северной и восточной экспозиций дали положительный эффект. Установлено, что всходы дружнее идут на мелких субстратах и в защищенных крупными породами местах. По степени всхожести семена дикой флоры не отличаются от семян культурных растений. 


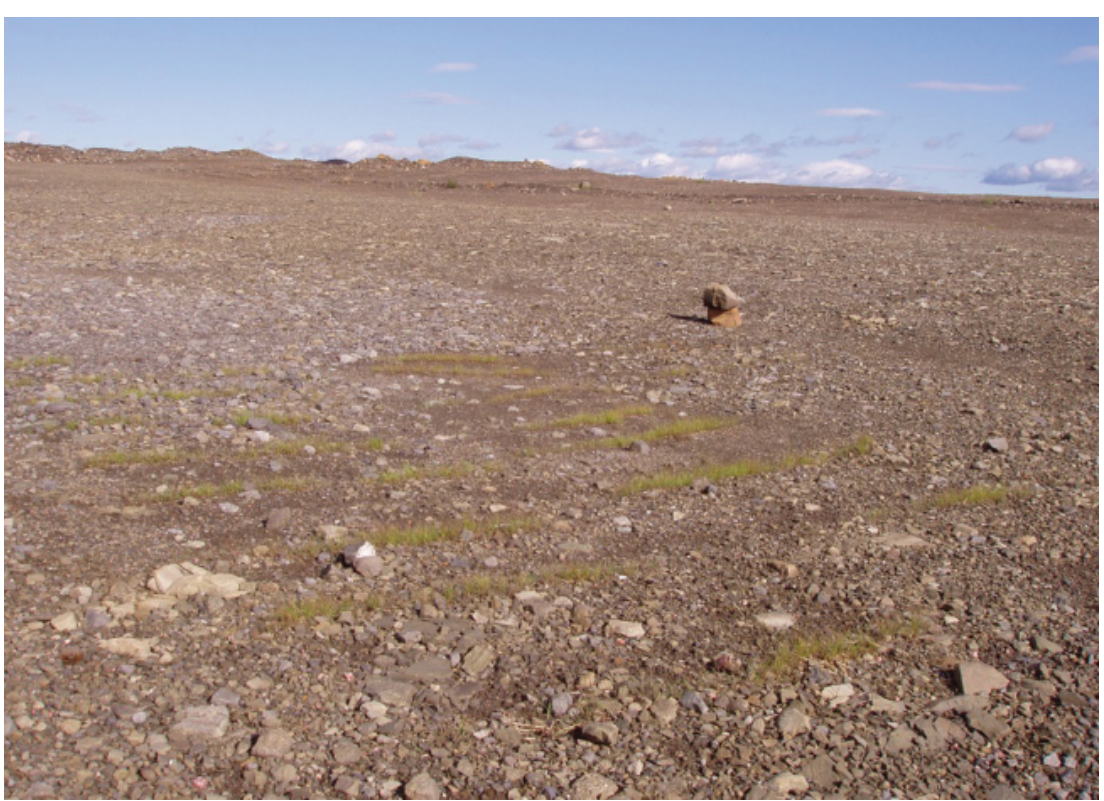

Рис. 5.3. Первые всходы на опытных делянах (2006 г.)

Летом 2006 года на опытном участке нами были посажены около 1000 черенков ольховника кустарникового и 15 черенков тополя душистого.

На следующий год выжили лишь единичные экземпляры тополя. Черенки тополя душистого по сравнению с черенками ольховника, оказались более выносливыми к условиям отвалов, т.к. выживаемость составила до $30 \%$.

Отрицательный результат опыта можно объяснить следующими причинами:

- были сильные ветры на поверхности отвалов, и более $50 \%$ черенков сдуты ветром;

- посадка черенков произведена без полива.

По сравнению с прошлым годом на отвале наблюдается зарастание растительности, особенно по откосам. На поверхности отвала заметно зарастание восточной части отвала, и на опытных участках и вне опыта. В защищенных от ветра местах высота единичных кустарников (ив и березы) достигает до 1,5 м, а подрост лиственницы и сосны - до 0,5-1 м. С каждым годом увеличивается проективное покрытие зеленых насаждений (от 5 до $15 \%$ в 10 кв. м). 
По результатам опыта 2006 года можно сделать следующие выводы:

1) посевы на отвалах эффективнее производить в весенний период (май-июнь) с обязательным внесением минеральных удобрений;

2) положительные результаты можно получить при посеве семян злаков и бобовых растений местных семенных хозяйств;

3) для ускорения зарастания отвалов можно использовать семена диких растений отвалов, их можно собрать осенью на промышленном отводе разреза.

По результатам опыта нами были разработаны научно-практические рекомендации по биологической рекультивации отвалов ХК «Якутуголь».

Предприятие в 2006 году создало ООО СМНП «Заречное» и начало проведение биологической рекультивации на отработанных отвалах и сдачи в хозяйственный оборот, результаты первые лет представлены в табл. 5.1.

Таблица 5.1

Результаты рекультивации отвалов разреза «Нерюнгринский»

\begin{tabular}{|l|c|c|c|c|c|}
\hline \multicolumn{1}{|c|}{ Отвалы } & $\begin{array}{c}\text { Техническая } \\
\text { рекультивация }\end{array}$ & \multicolumn{5}{|c|}{ Биологическая рекультивация } \\
\hline \multicolumn{7}{|c|}{2006 год } \\
\hline & & Саженцы & Семена & Удобрение & Площадь, га \\
\hline «Западный» & 40,02 га & 6751 шт. & 372 кг & 1718 кг & 26,03 \\
\hline \multicolumn{7}{|c|}{2007 год } \\
\hline «Западный» & 10284 шт. & 139 кг & 1689 кг & 8,04 га \\
\hline «Южный» & 7,85 га & 2125 шт. & 64 кг & 425 кг & 4,25 га \\
\hline
\end{tabular}

При технической рекультивации проводились:

- освобождение рекультивируемой поверхности от крупногабаритных обломков пород, мусора с последующим их захоронением или организованным складированием;

- формирование пологоволнистого рельефа в виде рядов;

- разрыхление плотной поверхности и предпосевное и предпосадочное оформление ее.

Технология подготовки выделенных участков к биологической рекультивации заключалась в 2-х вариантах:

- с нанесением слоя из мелкофракционных пород;

- без нанесения этого слоя.

Основными методами биологической рекультивации для ООО «Заречье» являются посев семян культурных видов злаков (пырейника сибирского) и бобовых (люцерны) сначала между рядами посадок, а затем в последующие годы - в междурядьях кустарниково-древесных видов (рис. 5.4). 

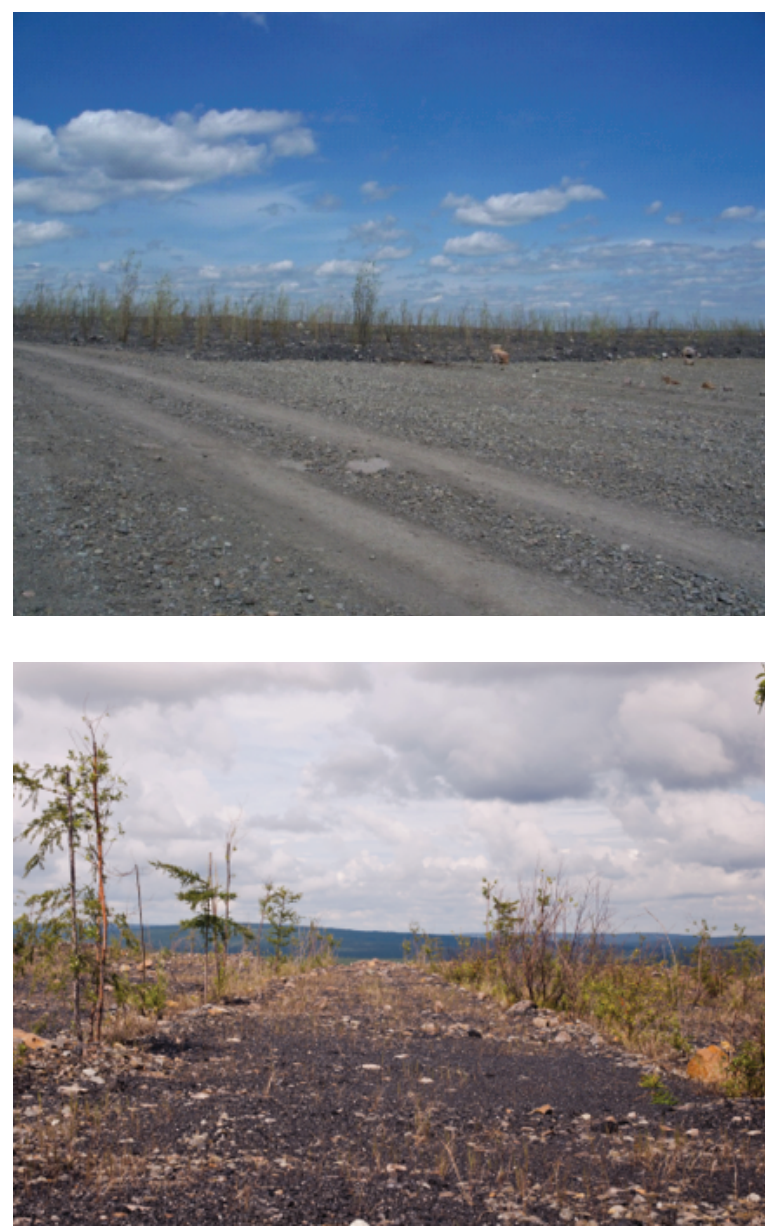

Рис. 5.4. Общий вид посадок, 2007 и 2016 годы

Уже в 2007 году опыты показали положительные результаты. Саженцы, посаженные в 2006 году, показали приживаемость до 50-80\%. Самая высокая степень приживаемости наблюдается у ив - до $100 \%$, тополя (до $90 \%$ ), подроста лиственницы (до $60 \%$ ), ольховника (до $60 \%$ ), сосны (до $50 \%)$. Установлено, что приживаемость больше зависит от возраста саженцев. Лучше растут молодые до 2-3-летнего возраста саженцы, более взрослые гибнут, но на их месте вырастают из боковых почек (рис. 5.5). 


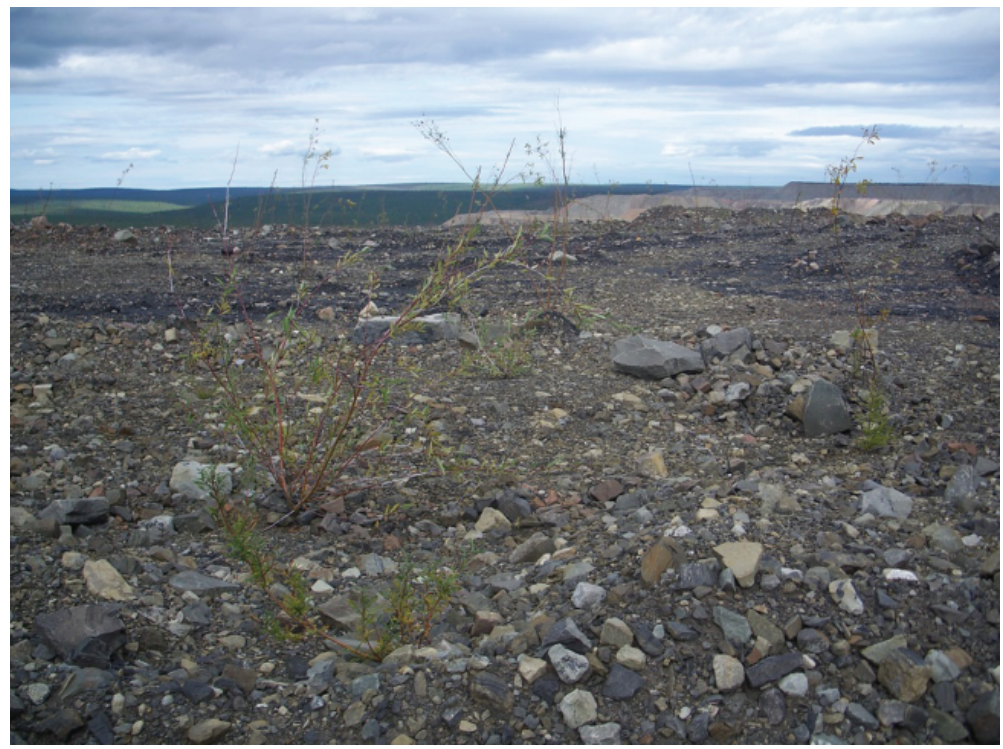

Рис. 5.5. Кустарники начинают рост и развитие, 2008 год

В 2007 году сотрудники «Заречное» заложило маленькие делянки с посевом семян дикой флоры между рядами саженцев. Осенью уже появились всходы одуванчика, иван-чая и других растений.

Опыты показали, что положительные результаты биологической рекультивации возможны при уходе за посадками и посевами.

ООО «Заречье» проводит внесение минеральных удобрений, стрижку саженцев, полив в сухое время и замену погибших саженцев новыми.

Из опытов заметно, что общее проективное покрытие растительности выше на участках без покрытия мелкофракционными породами отвалов обогатительной фабрики, т.е. эти материалы большого значения как субстрат не представляют.

Опытно-экспериментальные работы продолжались и в последующие годы. Всего за 2006-2007 годы по нашим рекомендациям предприятием было посажено саженцев древесно-кустарниковых растений на площади 43 га. И эти насаждения в определенной мере решат природоохранные задачи.

Варианты опыта будут продолжаться до тех пор, пока не будут установлены основные закономерности формирования искусственного растительного покрова. 


\section{ЗАКЛЮЧЕНИЕ}

Южная Якутия известна крупными месторождениями золота, угля и других полезных ископаемых. Крупным центром угледобывающей промышленности Якутии является разрез «Нерюнгринский», уголь добывается с 1970-х годов. В настоящее время к нему присоединились крупные месторождения «Эльгинское», «Денисовское» и другие.

Открытая добыча угля привело к значительным изменениям объектов природной среды, и в первую очередь, растительности. Частичное или полное уничтожение растительного покрова при открытой добыче полезных ископаемых не приводят к возобновлению естественной растительности, на техногенных ландшафтах начинают развиваться первичные сукцессии.

Изучение изменений в растительности в зоне влияния разреза «Нерюнгринский» показали следующее.

Прямые изменения видового состава растительности выявила ординация видов вдоль фактора загрязнения на расстоянии от карьера. В экоклине группы видов соответствуют определенной стадии сукцессии, направленной по розе ветров до 70 км от карьера. Причем, при переходе с одного уровня гемеробности (а- и олигогемеробных) к другому (поли- и гипергемеробным) растительность претерпевает значительные изменения в видовом составе и структуре сообществ.

Основными индикаторами воздействия пыли на растительности являются лишайники. В районе исследования выявлено 39 видов лишайников из 7 семейств, 13 родов. Ведущими семействами являются Cladoniaceae и Parmeliaceae, наибольшее количество видов представлено из рода Cladonia. Основу лихенофлоры территории составляют бореальные виды, а по ареалу преобладает мультирегиональные типы.

Видовой состав, среднее проективное покрытие и жизненное состояние лишайников также меняется при загрязнении). При сильном загрязнении (1 зона) наблюдается наибольшее количество видов лишайников, а при уменьшении степени загрязнения число видов постепенно уменьшается. Причем, эпифитные лишайник и оказались более выносливыми, чем эпигейные.

Изменение биохимического состава лишайников показало, что при наибольшей пылевой нагрузке происходит истощение антиоксидантной системы лишайников, вследствие этого резко растет окисление липидов, которое со временем приводит к разрушению комплекса белок-липид, 
патологии мембран и гибели клетки. Коэффициенты антиоксидантной защиты и антиоксидантно-прооксидантного равновесия у Cladina stellaris и Cetraria laevigata смещены в сторону усиления защитных реакций при переходе от загрязненной зоны к более чистой. Как видно из показателей $k_{\text {аоз }} / k_{\text {пол }}$ равновесие систем сильно нарушено и смещено в сторону ПОЛ у вида Cladina stellaris а вид Cetraria laevigata оказался наиболее устойчивым к неблагоприятным факторам окружающей среды, коэффициент равновесия смещен в сторону усиления антиоксидантной системы.

Изучение естественного зарастания промышленных отвалов разреза позволило оценить фитопригодность отвальных грунтов, скорость их зарастания, направление сукцессионных смен и по этим критериям выявить степень необходимости вмешательства человека в ход восстановительного процесса.

Зарастание отвалов и их заселение живыми организмами происходит спонтанно и в длительное время, поэтому необходимо искусственное восстановление растительного покрова путем рекультивации. Опытноэкспериментальные работы по биологической рекультивации отвалов разреза показали эффективность применения посева многолетней злаково-бобовой травосмеси без отсыпки плодородного слоя и с внесением минеральных удобрений и посадки 3-5-летних саженцев ольхи и тополя из окружающих зарастающих отвалов. Установлено, что при рекультивации отвалы начинают зарастать через 2-5 лет и образуя устойчивые растительные сообщества. 


\section{ПИТЕРАТУРА}

1. Акимов, А.К. Пути эффективного использования экономического и промышленного потенциала Южно-Якутского региона в XXI веке / А.К. Акимов // Пути эффективного использования экономического и промышленного потенциала Южно-Якутского региона в XXI веке / Сборник научных трудов. - Якутск: изд-во Якутского унта, 2000. - Т. 1. - С. 7-24.

2. Александрова, В.Д. Изучение смен растительного покрова / В.Д. Александрова // Полевая геоботаника. - М.-Л.: Наука, 1964. Т. 3. - С. 300-447.

3. Алексеев, В.Г. О характере изменений свойств пероксидазы при адаптации растений к экстремальным условиям Севера / В.Г. Алексеев, А.А. Попов, Б.М. Кершенгольц // Физиология растений. - 1983. Т. 30. - № 6. - С. 1094-1101.

4. Алексеев, В.Г. Устойчивость растений в условиях Севера: экологобиохимические аспекты / В.Г. Алексеев. - Новосибирск: Наука. Сибирская издательская фирма, 1994. - 152 с.

5. Андерсон, Ф.К. Реакция лишайника на атмосферные загрязнения / Ф.К. Андерсон, М. Трешоу // Загрязнения воздуха и жизнь растений. - Л.: Гидрометеоиздат, 1988. - С. 295-326.

6. Андреев, В.Н. Основные особенности растительного покрова Якутской АССР / В.Н. Андреев, Т.Ф. Галактионова, В.И. Перфильева, И.П. Щербаков. - Якутск: ЯФ СО АН СССР, 1987. - 156 с.

7. Андреева, В.А. Фермент пероксидаза / В.А. Андреева. - М.: Наука, 1988. - 127 с.

8. Артамонова, С.Ю. Роль геолого-геохимических методов при оценке воздействия горнодобывающих предприятий на природную среду / С.Ю. Артамонова, В.В. Иванов // Пути эффективного использования экономического и промышленного потенциала Южно-Якутского регионов XXI веке: сб. науч. тр. по матер. респ. науч.-практ. конф. - Нерюнгри: изд.-во ЯГУ, 2000. - С. 75-83.

9. Арчаков, А.И. Перекисное окисление в биологических мембранах / А.И. Арчаков, Ю.А. Владимиров. - М.: Наука, 1972. - 252 с.

10. Барабой, В.А. Перекисное окисление и стресс / В.А. Барабой, И.И. Брехман, В.Г. Голотин, Ю.Б. Кудряшов - СПб., 1992. - 148 с.

11. Баранник, Л.П. Биоэкологические принципы лесной рекультивации / Л.П. Баранник. - Новосибирск: Наука, 1988. 
12. Безуглова, О.С. Биогеохимия: учебник для студентов высших учебных заведений / О.С. Безуглова, Д.С. Орлов - Ростов на Дону: «Феникс», 2000. - 320 с.

13. Биккулова, А.Т. Биоэлементология s-, p-, d-элементов / А.Т. Биккулова, Г.М. Ищмуратова - СПб.: Наука, 1999. - 256 с.

14. Баумгертнер М.В. Лишайники - биоиндикаторы загрязнения окружающей среды юга Кемеровской области. Автореф. дис... канд. биол. наук. - Новосибирск, 1999. 17 с.

15. Биогеохимия растений. Труды Бурятского института естественных наук / отв. ред. А.Л. Ковалевский. - Улан-Удэ: Бурятское книжн. изд-во, 1969. - Вып. 2. - 224 с.

16. Биоиндикация загрязнений наземных экосистем / под ред. Р. Шуберта - М.: Мир, 1988.

17. Биологическая рекультивация на Севере (вопросы теории и практики) // Труды Коми фил. АН СССР. - Сыктывкар, 1992. вып. 3 - 104 с.

18. Биомониторинг загрязнения атмосферы с помощью растений / У.Д. Мэннинг, У.А. Федер. - Л.: Гидрометеоиздат, 1985. - 143 с.

19. Биоразнообразие ландшафтов Токинской котловины и хребта Токинский становик / А.П. Чевычелов и др. - Новосибирск: Издательство CO РAH, 2010. - $284 \mathrm{c}$.

20. Блюм, О.Б. Исторический аспект регионального мониторинга тяжелых металлов в атмосфере, осуществляемый методом БГХАиндикации / О.Б. Блюм, Ю.Г. Тютюнник // Проблемы экологического мониторинга и моделирования экосистем. - Том 12. - Л.: Гидрометеоиздат, 1989. - С. 73-87.

21. Болдырев, А.А. Биохимия мембран / А.А. Болдырев, Д.О. Левицкий // Кальций и биологические мембраны - Т. 7 - М.: Высшая школа, 1990. - 124 с.

22. Ботанические исследования в Якутии // Доклады юбилейной научной сессии, посвященной 50-летию Якутской АССР 1972 г. - Якутск: ЯФ СО АН СССР, 1975. - 156 с.

23. Бычев, М.И. Угли Якутии и перспективные направления их использования / М.И. Бычев, В.Л. Яковлев, Г.И. Петрова. - Якутск: ЯНЦ СО РАН, 1996. - 120 с.

24. Бязров, Л.Г. Лишайники в экологическом мониторинге / Л.Г. Бязров. - М.: Научный мир, 2002. - 336с.

25. Василенко, В.Н. Мониторинг загрязнения снежного покрова / В.Н. Василенко, И.М. Назаров, Ш.Д. Фридман. - Л.: Гидрометеоиздат, 1985. $-181 \mathrm{c}$. 
26. Ветров, В.А. Микроэлементы в природных средах, районе озера Байкал / В.А. Ветров, А.Н. Кузнецова. - Новосибирск: СО РАН НИЦ ОИГГМ, 1997. - 234 с.

27. Владимиров, Ю.А. Перекисные окисления липидов в биологических мембранах / Ю.А. Владимиров, А.И. Арчаков. - М., 1972. - 29 с.

28. Власова, Н.В. Новые и редкие виды флоры Южной Якутии / Н.В. Власова // Ботанический журнал. - 1984. - Т. 69. - № 8. - С. 1102-1104.

29. Волотовский, К.А. Флористические находки юго-восточной Якутии / К.А. Волотовский // Ботанический журнал. - 1989. - Т. 74. № 3. - С. 418-425.

30. Волотовский, К.А. Новые и редкие виды для флоры Алданского нагорья и Станового хребта (Южная Якутия) / К.А. Волотовский // Ботанический журнал. - 1991. - Т. 76. - № 6. - С. 39-47.

31. Волотовский, К.А. Типы поясности на Алданском нагорье / К.А. Волотовский // Х Всесоюзное совещание по изучению флоры и растительности высокогорий ЦСБС СО РАН. - Новосибирск, 1992. - С. 105.

32. Волотовский, К.А. Флористические находки на Алданском нагорье и хр. Токинский становик / К.А. Волотовский, Л.В. Кузнецова // Ботанический журнал. - 1993. - Т. 78. - № 1. - С. 88-92.

33. Волотовский, К.А. Новые данные о естественном гибриде Sorbocotoneaster pozdnjakowii (Rosaceae) / К.А. Волотовский, Л.В. Кузнецова // Ботанический журнал. - 1998. - Т. 83. - № 1. - С. 94-103.

34. Гаврилова, М.К. Климат и многолетнее промерзание горных пород / М.К. Гаврилова. - Новосибирск: Наука, 1978. - 214 с.

35. Гаврилова, М.К. Современный климат и вечная мерзлота на континентах / М.К. Гаврилова. - Новосибирск: Наука, 1981. - 113 с.

36. Галактионова, Т.Ф. Луга среднего течения р. Алдан / Т.Ф. Галактионова, А.А. Пермякова // Исследования почвенных, растительных и фаунистических ресурсов Якутии. - Якутск, 1964. -С. 75-79.

37. Галанин, А.А. Лихенометрическая индикация интенсивности некоторых экзогенных процессов / А.А. Галанин // Материалы первой конференции геокриологов России. - М.: МГУ, 1996. - С. 538-545.

38. Геология Якутской АССР. - М.: Недра, 1981. - 300 с.

39. Гончаров, Ю.Т. Региональные особенности разработки россыпей и рекультивации нарушенных земель в условиях Южной Якутии / Ю.Т. Гончаров // Проблемы техногенеза и рекультивации при разработке многолетнемерзлых россыпей. - Магадан, 1987. - С. 31-38.

40. Горовой, П.Г. Антиоксиданты в систематике растений / П.Г. Горовой, О.Б. Максимов // Хемосистематика и эволюционная биохимия высших растений. - М., 1986. - С. 48- 49. 
41. ГОСТ 41-08-205-99 «Управление качеством аналитической работы. Методики количественного химического анализа. Разработка, аттестация, утверждение»- М., 1999.

42. Григорьев, Ю.С. Трансплантационная лихеноиндикация загрязнения воздушной среды на основе замедленной флуоресценции хлорофилла / Ю.С. Григорьев, М.А. Бучельник // Экология. - 1997. № 6. - C. 465-467.

43. Дробов, В.П. Краткий очерк растительности Лено-Алданского плато / В.П. Дробов // Материалы комиссии по изучению ЯАССР. Вып. 8. - Л., 1927. - 85 с.

44. Егоров, А.Д. Микроэлементы в почвах и лугопастбищных растениях мерзлотных ландшафтов Якутии / А.Д. Егоров, Д.В. Григорьева, Т.Т. Курилюк, Н.Н. Сазонов. - Якутск, 1970. - 288 с.

45. Егоров, А.Д. Основные итоги биологических исследований в Якутской АССР / А.Д. Егоров. - Якутск, 1969. - С. 33-40.

46. Еленевский, Р.А. Природа Алданского края / Р.А. Еленевский // Природные ресурсы Южной Якутии в связи с социальной реконструкцией сельского хозяйства. - М.-Л., 1933. - С. 10-80.

47. Еловская, Л.Г. Классификация и диагностика мерзлотных почв Якутии / Л.Г. Еловская. - Якутск: ЯФ СО АН СССР, 1987. - 172 с.

48. Ермаков, А.И. Методы биохимических исследований растений / А.И. Ермаков, В.В. Арасимович. - Л.: Агропромиздат, 1987. - 456с.

49. Журавлев, А.И. Биоантиокислители в живых организмах / А.И. Журавлев // Биоантиокислители - М.: Наука, 1979. - С. 15-29

50. Закутнова, В.И. Влияние тяжелых металлов на лишайники / В.И. Закутнова, Т.А. Пилипенко // Вестник ОГУ. - 2004. - № 12. C. $112-116$.

51. Иванов, Б.И. Физиолого-биохимические исследования растений Якутии / Б.И. Иванов, В.Н. Дохунаев, В.Г. Алексеев, А.Д. Иванова Якутск, 1974. - С. 78-85.

52. Иванов, В.В. Атмосферный перенос загрязнителей при разработке угольных месторождений / В.В. Иванов // Проблемы и перспективы комплексного освоения месторождений полезных ископаемых криолитозоны: труды международной науч.-практ. конф. - Якутск: изд-во Института мерзлотоведения СО РАН, 2005. - Т. 3. - С. 155-159.

53. Иванов, В.В. Особенности загрязнения территории, прилегающей к карьеру «Нерюнгринский», выбросами в атмосферу / В.В. Иванов, Г.В. Назарова // Южная Якутия - новый этап индустриального развития: материалы междунар. науч.-практ. конф. - Нерюнгри: Изд-во Технического института, 2007. - Т. 2. - С. 31-34. 
54. Иванов, В.В. Предварительный экологический прогноз разработки Эльгинского месторождения / В.В. Иванов, Р.Н. Копылов, Т.С. Неустроева // Проблемы и перспективы освоения природных ресурсов Южной Якутии: сб. науч. тр. - Якутск: Изд-во Якутского ун-та, 1996. - С. 96-97.

55. Иванов, В.В. Современное состояние природной среды Южной Якутии / В.В. Иванов // Актуальные вопросы охраны окружающей среды и обеспечения экологической безопасности территорий крупномасштабного промышленного освоения: сб. матер. респ. сем.-совещ. Якутск: МОП РС (Я), 2007. - С. 34-38.

56. Иванов, В.В. Трансформация природных комплексов при недропользовании в условиях Якутии / В.В. Иванов. - Новосибирск: Наука, 2015. - $248 \mathrm{c}$.

57. Иванов, В.В. Экологические аспекты разработки угольных месторождений Северо-Востока России / В.В. Иванов. - М.: ООО НедраБизнесцентр, 2007. - 116 с.

58. Иванов, В.В. Экологические аспекты разработки угольных месторождений Северо-Востока России / В.В. Иванов; под ред. Ю.В. Шумилова. - М.: ООО «Недра-Бизнесцентр», 2007, - 116 с.

59. Иванов, В.В. Экологические аспекты разработки угольных месторождений Южной Якутии / В.В. Иванов [и др.] // Пути решения актуальных проблем добычи и переработки полезных ископаемых Южной Якутии: сб. материалов II респ. науч-практ. конф., г. Нерюнгри, 19-21 октября 2004 г. - Якутск: Изд-во Якутского гос. университета, 2005 г. - С. 254-260.

60. Иванова, Е.И. Листостебельные мхи Южной Якутии / Е.И. Иванова. - Новосибирск: Изд-во СО РАН, 2001. - 136 с.

61. Иванова, Е.И. Особенности бриофлоры нарушенных местообитаний Южной Якутии / Е.И. Иванова // Наука и образование. - 2003. № 1 (29). - С. 5-7.

62. Израэль, Ю.А. Об экологическом состоянии поверхностных вод / Ю.А. Израэль, В.А. Абакумов // Экологические модификации и критерии экологического нормирования. Труды межд. симп., Нальчик, 1-2 июня 1990 г. - Л.: Гидрометеоиздат, 1991.

63. Ильин, В.Б. Тяжелые металлы в системе почва-растения / В.Б. Ильин. - Новосибирск: Наука, 1991. - 151 с.

64. Илькун, Г.М. Загрязнители атмосферы и растения / Г.М. Илькун. - Киев.: Наук. думка, 1978. - 246 с.

65. Инсаров, Г.Э. Лишайники в условиях фонового загрязнения атмосферы двуокисью серы / Г.Э. Инсаров, И.Д. Инсарова // Проблемы экологического мониторинга и моделирования экосистем. - Т. 9. - Л.: Гидрометеоиздат, 1986. - С. 242-258. 
66. Инсаров, Г.Э. Система районирования земли для целей мониторинга эпифитных лишайников / Г.Э. Инсаров, И.Д. Инсарова // Проблемы экологического мониторинга и моделирования экосистем. Т. 9. - Л.: Гидрометеоиздат, 1986. - С. 112.

67. Инсаров, Г.Э. Сравнительные оценки чувствительности эпифитных лишайников различных видов к загрязнению воздуха / Г.Э. Инсаров, И.Д. Инсарова // Проблемы экологического мониторинга и моделирование экосистем. - Т. 12. - Л.: Гидрометеоиздат, 1989. - С. 113-175.

68. Инсарова, И.Д. Влияние сернистого газа на лишайники / И.Д. Инсарова // Проблемы экологического мониторинга и моделирования экосистем. - Л.: Гидрометеоиздат, 1982. - Т. 5. - С. 33-47.

69. Инсарова, И.Д. Влияние тяжелых металлов на лишайники // И.Д. Инсарова // Проблемы экологического мониторинга и моделирования экосистем. - Т. 6. - Л.: Гидрометеоиздат, 1983. - С. 101-113.

70. Инсарова, И.Д. Сравнительные оценки чувствительности эпифитных лишайников различных видов к загрязнению воздуха / И.Д. Инсарова, Г.Э. Инсаров // Проблемы экологического мониторинга и моделирования экосистем. - Т. 12. - Л.: Гидрометеоиздат, 1989. - С. 113-175.

71. Кабата-Пендиас, А. Микроэлементы в почвах и растениях / А. Кабата-Пендиас, Х. Пендиас. - М.: Мир, 1989. - 439 с.

72. Караваев, М.Н. К вопросу о геоботаническом районировании таежной зоны Якутии (краткие сообщения) / М.Н. Караваев // Вестник МГУ. Серия физ.-мат. и ест. наук. - Вып. 5. - № 8. - 1955. - С. 109-115.

73. Караваев, М.Н. Конспект флоры Якутии / М.Н. Караваев. - М., 1958. - $192 \mathrm{c}$.

74. Карпов, Д.Н. Градиентный анализ галофильных лугов пойм рек Башкирии / Д.Н. Карпов // Анализ закономерностей растительного покрова речных пойм. - Уфа, 1971. - С. 34-48.

75. Кершенгольц, Б.М. Структурное разнообразие биологически активных веществ - биохимическая основа толерантности организмов в стрессовых условиях среды / Б.М. Кершенгольц // Терпимость: идеи и традиции (матер. междунар. научной конф.). - Якутск: ЯНЦ СО РАН, 1995. - С. $179-184$.

76. Климовский, И.В. Криолитозона Якутской алмазоносной провинции / И.В. Климовский, С.П. Готовцев. - Новосибирск: ВО «Наука». Сибирская издательская фирма, 1994. - 168 с.

77. Ковальский, В.В. Геохимическая экология / В.В. Ковальский. М.: Наука, 1974. - 299 с.

78. Комаров, В.Л. Введение в изучение растительности Якутии / В.Л. Комаров // Труды комитета по изучению ЯАССР. - Л., 1926. - Т. 1. - 168 с. 
79. Коноровский А.К. Почвы севера зоны Малого БАМа. м Новосибирск: Наука, 1984. - 120 с.

80. Коржевин, В.С. Растительность долины Алдана / В.С. Коржевин // Тр. совета по изучению производительных сил, серия Якутская. Л.: Изд-во АН СССР, 1934. - Вып. 16. - 162 с.

81. Красавин, А.П. Экологические особенности и типизация техногенного воздействия угледобывающих предприятий на геологическую среду / А.П. Красавин, В.М. Баньковская // Проблемы безопасности при эксплуатации месторождений полезных ископаемых в зонах градопромышленных агломераций. Материалы Международного симпозиума SRM-95. - Екатеринбург: УрО РАН, 1997. - С. 413-419.

82. Красная книга Республики Саха (Якутия). Редкие и находящиеся под угрозой исчезновения виды растений и грибов. - Якутск, 2000. -256 с.

83. Крючков, В.В. Лишайники как биоиндикаторы качества окружающей среды в северной тайге / В.В. Крючков, Н.А. Сыроид // Экология. - 1990. - № 6. - С. 63-66.

84. Крючков, В.В. Предельные антропогенные нагрузки и состояние экосистем Севера / В.В. Крючков // Экология. - 1991. - № 3. - С. 28-40.

85. Крючков, В.В. Север на грани тысячелетий / В.В. Крючков. М.: Мысль, 1987. -268 с.

86. Кудинова, 3.А. Влияние угольного разреза «Нерюнгринский» (Южная Якутия) на сообщества лишайников / 3.А. Кудинова, В.В. Иванов // Проблемы региональной экологии. - М.: Маджента, 2008. № 2 - C. 76-78.

87. Кузнецова, В.Ф. Эпифитные лишайники как индикаторы загрязнения атмосферного воздуха газообразными поллютантами, тяжелыми металлами, радионуклидами: дисс. на соискание. уч. ст. канд. биол. наук / В.Ф. Кузнецова. - Нижний Новгород, 2004. - 161 с.

88. Кузнецова, Ф.С. История Сибири. Часть 1. Присоединение к России: учеб. пособ. для общеобр. учр. / Ф.С. Кузнецова. - Новосибирск: Инфолио-пресс, 2002. - 256 с.

89. Кузьмин, Ю.И. Биологическая рекультивация техногенных отвалов в условиях Крайнего Севера / Ю.И. Кузьмин // Экология. - 1985. № 2. - C. 21-24.

90. Ландшафтно-геохимические особенности формирования микроэлементозов в среднетаежной зоне Якутии / Г.Н. Саввинов [и др.]; под ред. Д.Д. Саввинова. - М.: ООО «Недра-Бизнесцентр», 2006. - 319 с.

91. Лебедева, Н.А. Биологическая рекультивация земель, нарушенных при добыче алмазов в Якутии / Н.А. Лебедева, А.Я. Лонкунова // Растения и промышленная среда. - Свердловск, 1990. - С. 71-75. 
92. Леса среднетаежной подзоны Якутии / П.А. Тимофеев, А.П. Исаев, И.П. Щербаков и др. - Якутск: ЯНЦ СО РАН, 1994. - 140 с.

93. Лощиц, Ю. Вехи русского освоения Якутии. Опыт кратчайшей хронологии / Ю. Лощиц // Русское воскресение (православие, самодержавие, народность). - 2002. - (http://www.voskres.ru/idea/yakutiya.htm).

94. Луга Якутии. - М.: Наука, 1975. - 175 с.

95. Макаров, В.Н. Геохимические поля в криолитозоне / В.Н. Макаров. - Якутск: Изд-во Ин-та мерзлотоведения СО РАН, 1998.

96. Макаров, В.Н. Геохимия снежного покрова Якутии / В.Н. Макаров, Н.Ф. Федосеев, В.И. Федосеева. - Якутск: Изд-во Ин-та мерзлотоведения СО РАН, 1990. - 152 с.

97. Макаров, В.Н. Комплексные экологические исследования на Эльгинском угольном месторождении (Южная Якутия)/ В.Н. Макаров [и др.]// Эколого-геохимические проблемы в районах криолитозоны. - Якутск: ИМЗ СО РАН - ассоциированный член изд-ва CO РAH, 1996. - C. 53-62.

98. Мельникова, Е.П. Биохимия окислительного стресса. Оксиданты и антиоксиданты / Е.П. Мельникова, И.К. Зенков, С.М. Шергин. - Новосибирск: Наука, - 1999. - 148 с.

99. Мильков, Ф.Н. Рукотворные ландшафты / Ф.Н. Мильков. - М: Мысль, 1978. - 84 с.

100. Мильков, Ф.Н. Человек и ландшафты. Очерки антропогенного ландшафтоведения / Ф.Н. Мильков. - М.: Мысль, 1973. - 224 с

101. Миркин, Б.М. Антропогенная динамика растительности / Б.М. Миркин // Итоги науки и техники. Ботаника. - М., 1984. T. 5. - C. 139-232.

102. Миркин, Б.М. Методика указания для практикума по классификации растительности методом Браун-Бланке / Б.М. Миркин. Уфа, 1985. - 32 с.

103. Миркин, Б.М. Словарь понятий и терминов современной фитоценологии / Б.М. Миркин, Г.С. Розенберг, Л.Г. Наумова. - М.: Наука, 1989. - 228 с.

104. Миркин Б.М. Современное состояние и тенденции развития классификации растительности методом Браун-Бланке // Итоги науки и техники. ВИНИТИ. Сер. Ботаника. - Т. 9 - М., 1989. - 128 с.

105. Миркин, Б.М. Фитоценология. Принципы и методы / Б.М. Миркин, Г.С. Розенберг. - М.: Наука, 1978. - 212 с.

106. Миронова, С.И. Динамика растительности техногенно нарушенных территорий Южной Якутии и возможности управления ею / С.И. Миронова // Наука и образование. - 1996. - № 4. - С. 140-148. 
107. Миронова С.И. Техногенные сукцессионные системы растительности в условиях криолитозоны. - Новосибирск: Наука, 2000. - 140 с.

108. Миронова, С.И. К вопросу восстановления техногенных земель Якутии / С.И. Миронова [и др.] // Прикладная экология Севера: Опыт проведения исследований, современное состояние и перспективы: междунар. науч.-практ. конф., г. Якутск, 20-21 марта 2003 г. - Якутск: ЯФ изд-ва СО РАН, 2003. - С. 177-184.

109. Миронова, С.И. О проблемах восстановления нарушенных земель Южной Якутии / С.И. Миронова, В.В. Иванов // Наука и образование. - 2001. - № 1. - С. 25-30.

110. Миронова, С.И. Первые опыты по рекультивации отвалов угольного разреза «Нерюнгринский» / С.И. Миронова [и др.] // Южная Якутия - новый этап индустриального развития: мат. междунар. науч.-практ. конф. - Нерюнгри: Изд-во Технического института, 2007. - T. 2. - C. 37-40.

111. Миронова, С.И. Проблемы и опыт рекультивации нарушенных земель на алмазных месторождениях Якутии: сб. докл. / С.И. Миронова, В.В. Иванов // Проблемы и пути эффективной отработки алмазоносных месторождений: междунар. науч.-практ. конф. - Новосибирск: Наука, 2011. - С. 521-523.

112. Миронова, С.И. Проблемы рекультивации земель при недропользовании на Севере / С.И. Миронова, В.В. Иванов // Наука и техника в Якутии. - 2011. - № 2 (21). - С. 49-51.

113. Миронова, С.И. Проблемы рекультивации техногенных участков месторождения «Биллях» / С.И. Миронова [и др.] // Экологическая безопасность при разработке россыпных месторождений алмазов: сб. науч. тр.; отв. ред. Н.Г. Соломонов, И.М. Охлопков. Якутск: СО РАН. Инс-т биологических проблем криолитозоны, 2004. - С. 190-197.

114. Миронова, С.И. Растительные ресурсы Южной Якутии в зоне влияния золотодобывающей промышленности и проблемы их оптимизации / С.И. Миронова, Н.Ф. Васильев, В.В. Иванов // Природные и интеллектуальные ресурсы Сибири (СИБРЕСУРС-7-2001): докл. 7-й междунар науч.-практ. конф., Барнаул, 17-19 сентября 2001 г. Томск: Изд.-во Том. ун-та, 2001. - С. 83-86.

115. Миронова, С.И. Рекультивация земель при разработке месторождений полезных ископаемых Якутии: уч. метод. пособие / С.И. Миронова, В.В. Иванов. - Якутск: Изд-во Якутского госуниверситета, 2005. - 65 с.

116. Миронова, С.И. Экологические основы восстановления отработанных угольных месторождений Якутии / С.И. Миронова, В.В. Иванов, В.Г. Тарабукина // Применение природосберегающих технологий 
в условиях холодных регионов: мат. IX Междунар. симп. по развитию холодных регионов, 1-5 июня 2010 г. - Якутск, 2010. - С. 92.

117. Моторина, Л.В. Ландшафтно-экологический подход к оптимизации природно-техногенных комплексов / Л.В. Моторина // Техногенные экосистемы. Организация и функционирование. - Новосибирск: Наука, 1985. - С. 12-23.

118. Научно-технические проблемы рекультивации земель, нарушенных при добыче полезных ископаемых в СССР (по материалам конференции в г. Орджоникидзе, Днепропетровской обл. 31 мая - 2 июня 1977 г.). - М.: ВИНИТИ, 1977. - 74 с.

119. Орлов, А.Г. Методы расчета в количественном спектральном анализе / А.Г. Орлов. - Л.: Ленинградское отделение, 1977. - 223 с.

120. Основные особенности растительного покрова якутской АССР. - Якутск: ЯФ АН СССР, 1987. - 154 с.

121. Особенности природопользования и перспективы природовосстановления на Крайнем Севере России / Н.С. Котелина. - Екатеринбург: УрО РАН, 1998. - 147 с.

122. Отчет о результатах «Геохимической съемки масштаба 1:200000 на территории места Q-50-XXVIII», выполненный ГУП ЯПСЭ на основании хоздоговора с БКГРЭ в 1996-1997 гг. - Якутск, 1998. м С. 170-194.

123. Петрова, А.Н. Выращивание многолетних злаковых трав на дражных полигонах в Южной Якутии / А.Н. Петрова // Освоение Севера и проблема рекультивации. - Сыктывкар, 1994. - С. 273-281.

124. Петрова, А.Н. Эколого-биологические особенности многолетних трав при выращивании на нарушенных землях Якутии / А.Н. Петрова // Проблемы экологии Якутии. Биогеографические исследования. Якутск, 1996. - Вып. 1. - С. 155-159

125. Петрова, Е.И. Почвы Южной Якутии / Е.И. Петрова. Якутск, 1971. - 167 с.

126. Поварницын, В.А. Леса долины р. Алдан от г. Томмота до устья Учура / В.А. Поварницын // Труды Ин-та по изучению леса. - Вып. 1. Л.: Изд-во АН СССР, 1932. - С. 155-231.

127. Поварницын, В.А. Леса долины р. Алдан от г. Томмота до устья p. Ноторы / В.А. Поварницын // Труды Ин-та по изучению леса. Вып. 1. - Л.: Изд-во АН СССР, 1933. - С. 688-691.

128. Поздняков, Л.К. Межродовой гибрид из семейства розоцветных / Л.К. Поздняков // ДокЛ. АН СССР. - 1952. - Т. 85. - № 5. C. $1161-1164$.

129. Поздняков, Л.К. Леса и лесные ресурсы Южной Якутии / Л.К. Поздняков, В.И. Гортинский. - М.: Изд. АН СССР, 1960. - 153 с. 
130. Поздняков, Л.К. Лиственничные и сосновые леса верхнего Алдана / Л.К. Поздняков. - М.: Изд-во АН СССР, 1961. - 175 с.

131. 131.Поздняков, Л.К. Леса Якутской АССР / Л.К. Поздняков // Леса СССР. - М.: Наука, 1969. - Т. 4. - С. 469-537.

132. Поисеев, И.И. Устойчивое развитие Севера: эколого-экономический аспект / И.И. Поисеев. - Новосибирск: Наука. Сибирская издательская фирма РАН, 1999. - 280 с.

133. Полевая геоботаника. Том V / под ред. Е.М. Лавренко, А.А. Корчагин. - Л.: Изд.: Наука, 1976. - 320 с.

134. Порядина Л.Н. История изучения лишайников Якутии / Л.Н. Порядина // Актуальные вопросы биологических наук. - 2011. № 17-1. - С. 6-24.

135. Порядина Л.Н. Флора и растительность в зоне строительства ГЭС на р. Тимптон / Л.Н. Порядина // Сборник статей «Научное обеспечение реализации мегапроектов в Республике Саха (Якутия)». - Якутск: Компания «Дани Алмас», 2009. - С. 173-178.

136. Порядина, Л.Н. Лихенофлора / Л.Н. Порядина // Биоразнообразие ландшафтов Токинской котловины и хребта Токинский Становик (коллективная монография) / отв. ред. Б.И. Иванов. - Новосибирск: изд-во СО РАН, 2010. - С. 140-141.

137. Порядина, Л.Н. Лишайники бассейна реки Алгама (Южная Якутия) / Л.Н. Порядина // Сибирский экологический журнал. - 2007. № 3 - C. 417-420

138. Пояркова, А.И. Sorbocotoneaster Pojark. - новый естественный межродовой гибрид / А.И. Пояркова // Ботанические материалы Гербария БИН им. В.Л. Комарова АН СССР. - 1953. - Т. 15. - С. 92-108.

139. Природно-техногенные экосистемы Южной Якутии / В.В. Иванов [и др.]: под ред. В.А. Шерстова. - М.: ООО «Недра-Бизнесцентр», 2006. - 186 с.

140. Программа и методика биогеоценотических исследований. М.: Наука, 1974. - 401 с.

141. Производственное объединение «Якутуголь». - Иркутск: Управполтграфиздат, 1986. - 44 с.

142. Разнообразие растительного мира Якутии / В.И. Захарова и др. Новосибирск: Изд-во СО РАН, 2005. - 328 с.

143. Разумовский, С.М. Закономерности динамики биоценозов / С.М. Разумовский. - М.: Наука. Сиб. отд., 1981. - 232 с.

144. Растительный покров СССР. Пояснительный текст к «Геоботанической карте СССР». - Т. 1. - М.-Л.: Изд-во АН СССР, 1956a. - C. 1-460. 
145. Растительный покров СССР. Пояснительный текст к «Геоботанической карте СССР». - Т. 2. - М.-Л.: Изд-во АН СССР, 1956б. - С. 460-972.

146. Региональное природопользование: методы изучения, оценки и управления: уч. пособие / П.Я. Бакланов [и др.]: под ред. Бакланова, В.П. Каракина. - М.: Логос, 2002. - 160 с.

147. Реймерс, Н.Ф. Природопользование: Словарь-справочник / Н.Ф. Реймерс. - М.: Мысль, 1990. - 637 с.

148. Рекомендации по отводу под самозарастание земель, нарушенных горными работами (на примере Южной Якутии) [Текст] / С.И. Миронова [и др.]; отв. ред. Д.Д. Саввинов. - Якутск: АН РС (Я). Инст. прикладной экологии Севера, 2001. - 81 с.

149. Рогожин, В.В. Методы биохимических исследований / В.В. Рогожин. Якутск, 1999. - 113 с.

150. Русанов, А.К. Основы количественного спектрального анализа руд и минералов / А.К. Русанов. - М.: Недра, 1978. - 400 с.

151. Русанов, Б.С. Геоморфология Восточной Якутии / Б.С. Русанов, 3.Ф. Бороденкова, В.Ф. Гончаров и др. - Якутск, 1967. - 375 с.

152. Рыкова, Ю.В. Низшие растения: методическое указания / Ю.В. Рыкова. - Якутск: издательство ЯГУ, 2002. - 164 с.

153. Рыкова, Ю.В. Определитель листоватых и кустистых лишайников Якутии: учебное пособие / Ю.В. Рыкова. - Якутск: изд. Якутского университета, 1996. - 91 с.

154. Саввинов, Г.Н. Эколого-почвенные комплексы Якутии / Г.Н. Саввинов. - М.: ООО «Недра-Бизнесцентр», 2007. - 312 с.

155. Саввинов, Д.Д. Микроэлементы в северных экосистемах: на примере республики Саха (Якутия) / Д.Д. Саввинов, Н.Н. Сазонов. Новосибирск: Наука, 2006. - 208 с.

156. Саввинов, Д.Д. Об устойчивости мерзлотных биогеоценозов к антропогенному воздействию / Д.Д. Саввинов // География и природные ресурсы. - Новосибирск: Наука, 1981. - С. 124-125.

157. Самозарастание нарушенных земель Севера: монография / Л.П. Капелькина, О.И. Сумина, И.А. Лавриненко и др. - СПб.: Изд-во BBM, 2014. - 204 c.

158. Сборник инновационных решений по сохранению биоразнообразия для угледобывающего сектора. - М., 2015. - 206 с.

159. Скрябин, С.3. Зеленый покров Якутии / С.3. Скрябин, М.Н. Караваев. - Якутск: кн. изд-во, 1991. - 176 с.

160. Сумина, О.И. Техногенное воздействие на тундровые экосистемы и рекультивация нарушенных территорий / О.И. Сумина. - СПб.: ЛГУ, 1992. - 42 с. 
161. Тарабукина, В.Г. Свойства пород отвалов и особенности почвообразования в техногенных ландшафтах / В.Г. Тарабукина // Наука и образование. - Якутск, 1996. - № 4. - С. 153-159.

162. Тимофеев, П.А. Леса Якутии. Состав, ресурсы, использование и охрана / П.А. Тимофеев. - Новосибирск: Изд-во СО РАН, 2003. - 194 с.

163. Тишков, А.А. Экологические исследования нарушенных экосистем Севера / А.А. Тишков. - М.: Наука, 1996. - 138 с.

164. Трасс, Х.X. Частные методы лихеноиндикации / X.X. Трасс // Биогеохимические аспекты криптоиндикации. Тезисы докладов на Всесоюзной конференции «Биогеохимический круговорот веществ». - Таллин, 1982. - С. 33-34.

165. Трасс, Х.X. Классы полеотолерантности лишайников и экологический мониторинг / Х.Х. Трасс // Проблемы экологического мониторинга и моделирования экосистем. - Л.: Гидрометеоиздат, 1985. T. 8 - C. $122-137$.

166. Трасс, Х.Х. Успехи и проблемы лихеноиндикации загрязнённости воздуха / X.X. Трасс // Лихеноиндикация состояния окружающей среды. - Таллин, 1978.

167. Трешоу, М. Введение / M. Трешоу // Загрязнение воздуха и жизнь растений. - Л., 1988. - С. 15-23.

168. Тюлина, Л.Н. Лесная растительность средней и нижней части бассейна р. Учур / Л.Н. Тюлина. - М.;Л.: Изд-во АН СССР, 1962. - 149 с.

169. Тюлина, Л.Н. Лесная растительность среднего и нижнего течения р. Юдомы и низовьев р. Маи Алдана / Л.Н. Тюлина. - М.: АН СССР, 1959. - 222 с.

170. Тюлина, Л.Н. Очерк лесной растительности верхнего течения р. Алдана / Л.Н. Тюлина // Тр. Инст. биол. - Вып. 3. - М., 1957. - С. 83-138.

171. Угольная база России. Угольные бассейны и месторождения Дальнего Востока России (Республика Саха, Северо-Восток, о.Сахалин, п-ов Камчатка). - М.: ЗАО «Геоинформмарк», 1999. - Т. 5. - Кн. 2. - 638 с.

172. Федоров, А.Н. Мерзлотные ландшафты Якутии: методика выделения и вопросы картографирования / А.Н. Федоров. - Якутск: Инст-т мерзлотоведения СО АН СССР, 1991. - 140 с.

173. Федоров, А.Н. Мерзлотные ландшафты, их устойчивость и восстановление / А.Н. Федоров // Лес и вечная мерзлота. - Якутск, 2000. - С. 17-21.

174. Флора Якутии: географический и экологический аспекты / Л.В. Кузнецова, В.И. Захарова, Н.К. Сосина и др. - Новосибирск: Наука, 2010. - $192 \mathrm{c}$.

175. Хатылаев, М.М. Промышленное развитие Якутии в 19461960 гг. / М.М. Хатылаев. - Якутск: ЯНЦ СО РАН, 1992. - 184 с. 
176. Цыганков, А.В. Безопасность освоения месторождений полезных ископаемых в криолитозоне / А.В. Цыганков. - Якутск: ЯНЦ СО PAH, 1994. - $112 \mathrm{c}$.

177. Чевычелов, А.П. Поглощение микроэлементов эпигейными лишайниками Южной Якутии / А.П. Чевычелов // Известия сибирского отделения АН СССР серия биологических наук. - Вып. 2. - 1990. - С. 39-44.

178. Шадрина, Е.Г. Биоиндикация воздействия горнодобывающей промышленности на наземные экосистемы Севера / Е.Г. Шадрина, Я.Л. Вольперт, В.А. Данилов, Д.Я. Шадрин. - Новосибирск: Наука, 2003. $-110 \mathrm{c}$.

179. Шапиро, И.А. Обзор современного состояния хемосистематики лишайников / И.А. Шапиро // Новости сист. низш. раст. - Л., 1980. Т. 17. - C.153-157.

180. Шапиро, И.А. Физиолого-биохимические изменения у лишайников под влиянием атмосферного загрязнения / И.А. Шапиро // Успехи современной биологии. - Т. 2. - 1996. - С. 158-171.

181. Шац, М.М. Дистанционные эколого-геокриологические исследования / М.М. Шац. - Якутск: ИМЗ СО РАН - ассоциированный член изд-ва СО РАН, 1997. - 80 с.

182. Шелудякова, В.А. Луга и пастбища центральной и юго-западной Якутии / В.А. Шелудякова. - Якутск, 1959. - 110 с.

183. Шепелев, В.В. Районирование территории РФ по условиям проживания с учетом геокриологической обстановки / В.В. Шепелев, М.М. Шац // Наука и образование. - 2005. - № 4. - С. 72-79.

184. Шиндлер Д.Р. Микроэлементы в почвах Южной Якутии / Д.Р. Шиндлер, А.П. Чевычелов. - Новосибирск, 1992. - 105 с.

185. Шишигин, П.Р. Потенциал горно-добывающего комплекса Республики Саха (Якутия) / П.Р. Шишигин, К.К. Ильковский // Горнодобывающая промышленность Республики Саха (Якутия). Проблемы и перспективы. Тезисы докладов науч. - практ. конф., посвященной 300-летию учреждения в России Приказа рудокопных дел. - Якутск, Сахаполиграфиздат, 2000. - С. 12-26.

186. Шумилов, Ю.В. Проблемы и практика экологического нормирования на Севере / Ю.В. Шумилов [и др.]. - Якутск: Якутский филиал Изд-ва СО РАН, 2001. - 325 с.

187. Щелчкова, М.В. Влияние выбросов Нерюнгринской ГРЭС на окружающую среду / М.В. Щелчкова // Наука и образование. - 1998. № 1. - Якутск: Изд-во ЯНЦ СО РАН. - С. 120-124.

188. Щербаков, И.П. Леса и лесная промышленность Якутии / И.П. Щербаков, Г.Т. Уртаев. - М.-Л.: Гослесбумиздат, 1961. - 108 с. 
189. Щербаков, И.П. Лесной покров Северо-Востока СССР / И.П. Щербаков. - Новосибирск: Наука, 1975. - 344 с.

190. Щербаков, И.П. Типы леса Южной Якутии / И.П. Щербаков // Леса Южной Якутии. - М.: Наука, 1964. - С. 5-109.

191. Экогеохимия городов Восточной Сибири / И.С. Ломоносов [и др.]. - Якутск: Ин-т мерзлотоведения СО РАН, 1993. - 108 с.

192. Экологическая безопасность Якутии: материалы науч.-практ. конф., посвящ. 15-летию ФГНУ ИПЭС (Якутск, 7-8 февраля 2008 г.

193. Элькин, А.Я. Метод выбора оптимальных технологических схем технической рекультивации / А.Я. Элькин, А.Г. Рязанов // Технология рекультивации и охрана земель при разработке рудных месторождений. Труды ИГД МЧМ СССР. - Свердловск: ПО «Полиграфист», 1983. - С. 12-18.

194. Эскин, В.С. Рекультивация земель, нарушенных открытыми разработками / В.С. Эскин. - М.: Недра, 1975.

195. Южная Якутия / под ред. В.А. Кудрявцева. - М.: МГУ, 1975. - 444 с.

196. Южная Якутия: потенциал и территориальная организация хозяйственного комплекса / Е.Г. Егоров и др. - СПб.: Изд-во Политехн. Ун-та, 2013. - 308 с.

197. Constantine, N.G. Superoxide Dismutases in hanger plants / N.G. Constantine, K.R. Stanley // Plant Physiol. - 1977. - V. 59. - P. 565-569.

198. Willard, E. Effect of human activities on alpine tundra ecosystems in Rocky Mountains National Park. Colorado / E. Willard, J.W. Marr // Biol. Conserv. - 1970. - Vol. 2. - № 4. - P. 257-265. 
Научное издание

Миронова Светлана Ивановна

Иванов Василий Васильевич

\section{ДОБЫЧА УГЛЯ В ЮЖНОЙ ЯКУТИИ И ЕЕ ВОЗДЕЙСТВИЕ НА РАСТИТЕЛЬНОСТЬ (на примере разреза «Нерюнгринский»)}

Монография

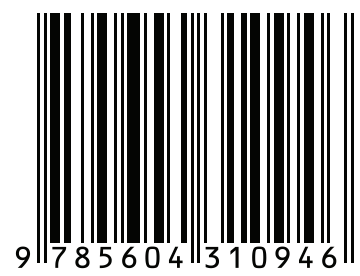

Технический редактор Кулакова Г.А.

Подписано в печать 25.09.2019

Бумага офсетная.

Гарнитура NewtonC

Формат $60 \times 841 / 16$

Печать трафаретная. Печ. л. 6,38.

Тираж 500 экз. Заказ № 015-19.

Отпечатано в типографии Евроазиатской научно-промышленной палаты, 410035 , г. Саратов, ул. Мамонтовой, д. 5 